Prepared in cooperation with the Arizona Department of Water Resources and Mohave County, Arizona

\title{
Hydrogeologic Framework and Estimates of Groundwater Storage for the Hualapai Valley, Detrital Valley, and Sacramento Valley Basins, Mohave County, Arizona
}

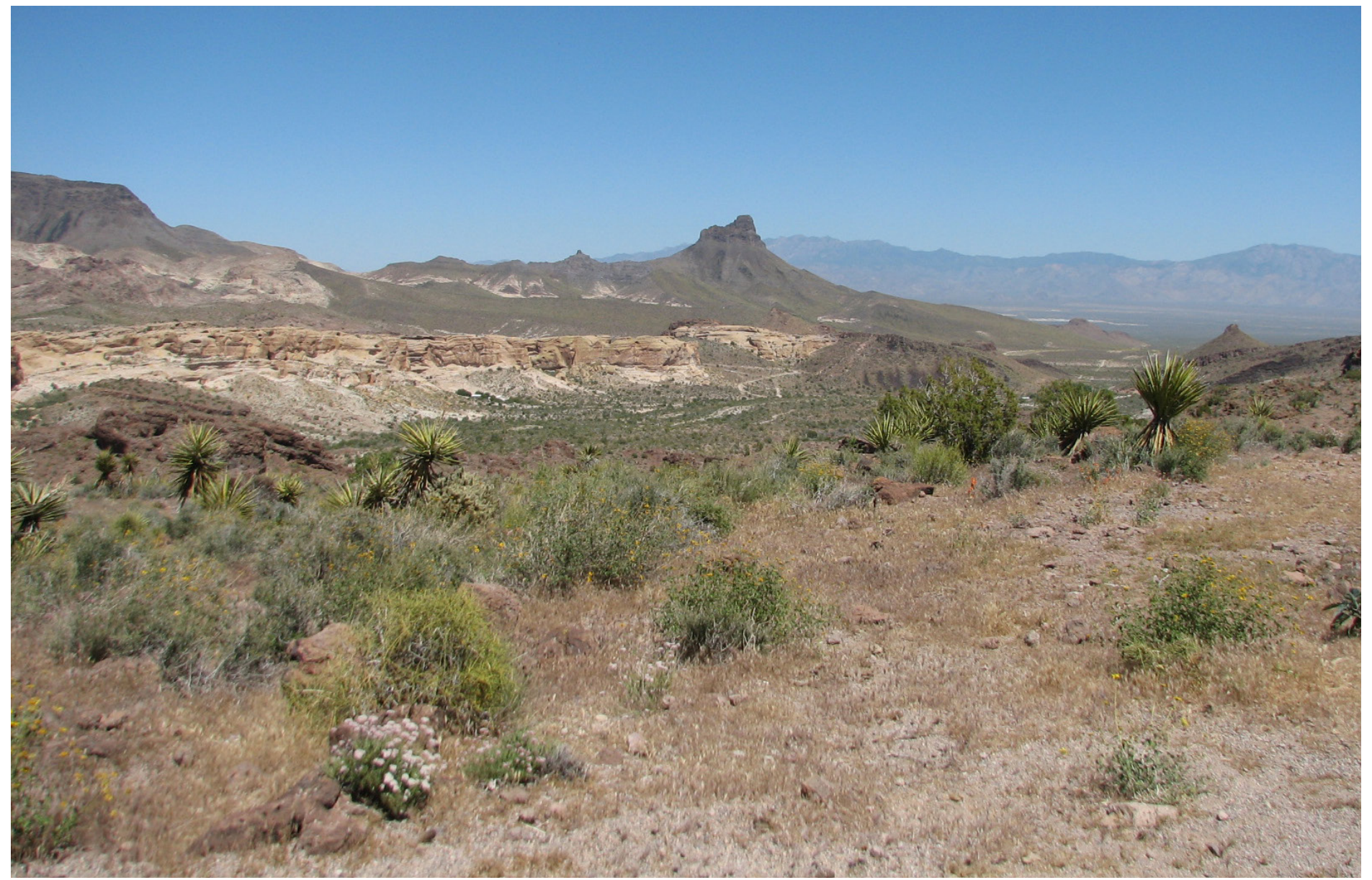

Scientific Investigations Report 2012-5275 
FRONT COVER:

Desert in Mohave County, Arizona. Photo by Margot Truini. 
Prepared in cooperation with the

Arizona Department of Water Resources and Mohave County, Arizona

\section{Hydrogeologic Framework and Estimates of Groundwater Storage for the Hualapai Valley, Detrital Valley, and Sacramento Valley Basins, Mohave County, Arizona}

By Margot Truini, L. Sue Beard, Jeffrey Kennedy, and David W. Anning

Scientific Investigations Report 2012-5275 


\section{U.S. Department of the Interior \\ KEN SALAZAR, Secretary}

\section{U.S. Geological Survey \\ Suzette M. Kimball, Acting Director}

U.S. Geological Survey, Reston, Virginia 2013

For more information on the USGS - the Federal source for science about the Earth, its natural and living resources, natural hazards, and the environment - visit http://www.usgs.gov or call 1-888-ASK-USGS

For an overview of USGS information products, including maps, imagery, and publications, visit http://www.usgs.gov/pubprod

To order this and other USGS information products, visit http://store.usgs.gov

Any use of trade, firm, or product names is for descriptive purposes only and does not imply endorsement by the U.S. Government.

Although this information product, for the most part, is in the public domain, it also may contain copyrighted materials as noted in the text. Permission to reproduce copyrighted items must be secured from the copyright owner.

Suggested citation:

Truini, M., Beard, L.S., Kennedy, J., Anning, D.W., 2013, Hydrogeologic framework and estimates of groundwater storage for the Hualapai Valley, Detrital Valley, and Sacramento Valley basins, Mohave County, Arizona: U.S. Geological Survey Scientific Investigations Report 2012-5275, 47 p. 


\section{Contents}

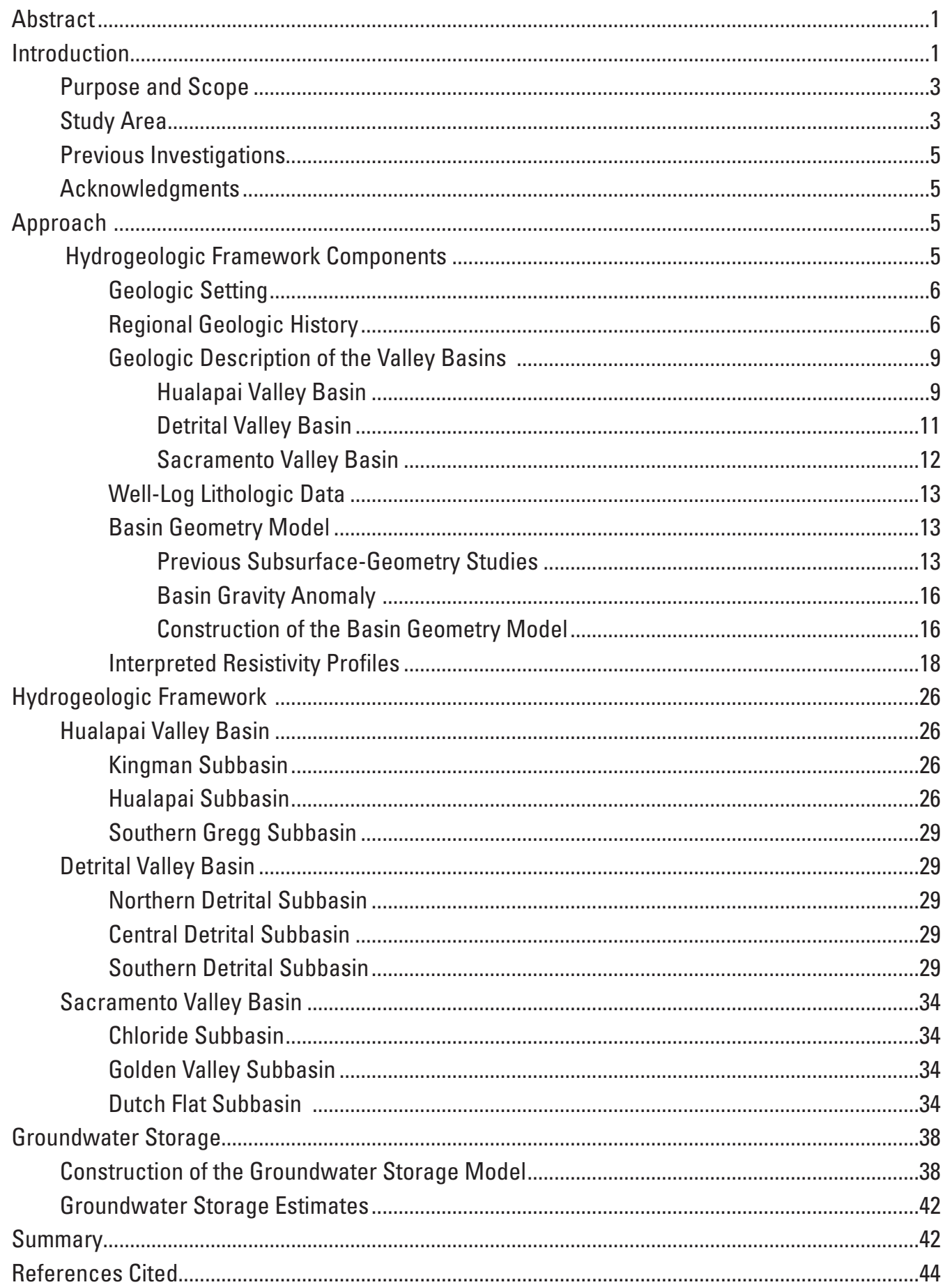




\section{Figures}

1. Mohave County, northwest Arizona, showing physiography and location of the study area in the Hualapai Valley, Detrital Valley, and Sacramento Valley basins .

2. Mohave County, northwest Arizona, showing the physiography and distribution of precipitation...

3. Mohave County, northwest Arizona, showing surface geology and structure in Hualapai Valley, Detrital Valley, and Sacramento Valley basins ..

4. Schematic cross-sections showing extensional-basin evolution, structural and stratigraphic relations between older and younger basin fill, volcanic rocks, and older and younger surficial deposits.

5. Photographs showing exposed sedimentary deposits of active playa deposits in Red Lake playa..

6. Mohave County, northwest Arizona, showing location of wells into volcanic and crystalline rocks

7. Mohave County, northwest Arizona, showing location of wells in the Arizona Department of Water Resources database (Wells55) and from the U.S. Geological Survey Groundwater Information Systems database.

8. Basin gravity anomaly in Mohave County, northwest Arizona

9. Basin geometry model showing subbasins and estimated depth in the Hualapai Valley, Detrital Valley, and Sacramento Valley Basins, Mohave County, northwestern Arizona

10. Histogram of difference in bedrock depth between the basin geometry model and well logs

11. Mohave County, northwest Arizona, showing location of GEOTEM surveys in the Hualapai Valley, Detrital Valley, and Sacramento Valley basins.

12. Mohave County, northwest Arizona, showing perspective view to the northeast in the Golden Valley subbasin, Sacramento Valley basin, with example of where the basin geometry model did not match GEOTEM profiles and well-log lithologic interpretation of boundary between volcanic bedrock and basin fill

13. Mohave County, northwest Arizona, showing perspective view to the northeast in the Golden Valley subbasin of the Sacramento Valley basin, with interpretation of high transient electromagnetic resistivity values $>100 \Omega \bullet m$

14. Mohave County, northwest Arizona, showing perspective view to northeast in the Golden Valley subbasin, Sacramento Valley Basin, with example of the uninterpreted resistivity profile.

15. Mohave County, northwest Arizona, showing perspective view to the northeast of uninterpreted and interpreted resistivity from GEOTEM profiles in northern part of the Kingman subbasin of the Hualapai Valley basin.

16. Mohave County, northwest Arizona, showing perspective view to northwest, of uninterpreted and interpreted resistivity from GEOTEM profiles in Hualapai subbasin, Hualapai Valley basin

17. Mohave County, northwest Arizona, showing perspective view to the northwest of uninterpreted and interpreted resistivity from GEOTEM profiles in southern Gregg subbasin, Hualapai Valley basin.

18. Mohave County, northwest Arizona, showing perspective view to the northeast of uninterpreted and interpreted resistivity from GEOTEM profiles in northern Detrital subbasin, Detrital Valley basin. 31

19. Mohave County, northwest Arizona, showing perspective view to the northeast of uninterpreted and interpreted resistivity from GEOTEM profiles in the central subbasin in 
Detrital Valley basin.

20. Mohave County, northwest Arizona, perspective view showing vertical changes in resistivity with depth from unsaturated to saturated basin fill on GEOTEM profile D8 overlain on the basin geometry model in the central Detrital subbasin of the Detrital Valley basin..

21. Mohave County, northwest Arizona, showing perspective view to the northeast of uninterpreted resistivity and interpreted resistivity from GEOTEM profiles in the southern Detrital subbasin in Detrital Valley basin..

22. Mohave County, northwest Arizona, showing perspective view to the northeast of uninterpreted and interpreted resistivity for GEOTEM profiles in the Chloride subbasin of the Sacramento Valley basin.

23. Mohave County, northwest Arizona, showing perspective view to the northeast of uninterpreted resistivity and interpreted resistivity for GEOTEM profiles in Golden Valley subbasin of the Sacramento Valley basin

24. Mohave County, northwest Arizona, showing perspective view to the northeast of uninterpreted and interpreted resistivity from GEOTEM profiles in the Dutch Flat subbasin of the Sacramento Valley basin..

25. Mohave County, northwest Arizona, showing areas of modeled saturated sediments delineating hydrogeologic unit areas in the Hualapai Valley, Detrital Valley, and Sacramento Valley basins . .41

\section{Tables}

1. Geologic units and correlation to lithologic description and depositional setting in the Hualapai Valley, Detrital Valley, and Sacramento Valley basins, Mohave County, Arizona.....7

2. Generalized grouping of lithology from well logs .......................................................................12

3. Relation between lithology and approximate ranges in resistivity values ...............................22

4. Estimated groundwater storage in basin-fill aquifers to 400 meters below land surface in the Hualapai Valley, Detrital Valley, and Sacramento Valley basins, Mohave County, Arizona. 


\section{Conversion Factors}

\begin{tabular}{|c|c|c|}
\hline \multicolumn{3}{|l|}{ SI to Inch/Pound } \\
\hline Multiply & By & To obtain \\
\hline \multicolumn{3}{|c|}{ Length } \\
\hline centimeter $(\mathrm{cm})$ & 0.3937 & inch (in.) \\
\hline millimeter (mm) & 0.03937 & inch (in.) \\
\hline meter $(\mathrm{m})$ & 3.281 & foot $(\mathrm{ft})$ \\
\hline kilometer $(\mathrm{km})$ & 0.6214 & mile (mi) \\
\hline meter $(\mathrm{m})$ & 1.094 & yard (yd) \\
\hline \multicolumn{3}{|c|}{ Volume } \\
\hline liter $(\mathrm{L})$ & 33.82 & ounce, fluid (fl.oz) \\
\hline liter $(\mathrm{L})$ & 2.113 & pint (pt) \\
\hline liter (L) & 1.057 & quart (qt) \\
\hline liter (L) & 0.2642 & gallon (gal) \\
\hline cubic meter $\left(\mathrm{m}^{3}\right)$ & 264.2 & gallon (gal) \\
\hline cubic decimeter $\left(\mathrm{dm}^{3}\right)$ & 0.2642 & gallon (gal) \\
\hline cubic meter $\left(\mathrm{m}^{3}\right)$ & 0.0002642 & million gallons (Mgal) \\
\hline cubic centimeter $\left(\mathrm{cm}^{3}\right)$ & 0.06102 & cubic inch $\left(\mathrm{in}^{3}\right)$ \\
\hline cubic decimeter $\left(\mathrm{dm}^{3}\right)$ & 61.02 & cubic inch $\left(\right.$ in $\left.^{3}\right)$ \\
\hline liter (L) & 61.02 & cubic inch $\left(\mathrm{in}^{3}\right)$ \\
\hline cubic meter $\left(\mathrm{m}^{3}\right)$ & 35.31 & cubic foot $\left(\mathrm{ft}^{3}\right)$ \\
\hline cubic meter $\left(\mathrm{m}^{3}\right)$ & 1.308 & cubic yard $\left(\mathrm{yd}^{3}\right)$ \\
\hline cubic kilometer $\left(\mathrm{km}^{3}\right)$ & 0.2399 & cubic mile $\left(\mathrm{mi}^{3}\right)$ \\
\hline cubic meter $\left(\mathrm{m}^{3}\right)$ & 0.0008107 & acre-foot (acre-ft) \\
\hline
\end{tabular}




\title{
Hydrogeologic Framework and Estimates of Groundwater Storage for Hualapai Valley, Detrital Valley, and Sacramento Valley Basins, Mohave County, Arizona
}

\author{
By Margot Truini, L. Sue Beard, Jeffrey Kennedy, and David W. Anning
}

\section{Abstract}

We have investigated the hydrogeology of the Hualapai Valley, Detrital Valley, and Sacramento Valley basins of Mohave County in northwestern Arizona to develop a better understanding of groundwater storage within the basin fill aquifers. In our investigation we used geologic maps, well-log data, and geophysical surveys to delineate the sedimentary textures and lithology of the basin fill. We used gravity data to construct a basin geometry model that defines smaller subbasins within the larger basins, and airborne transientelectromagnetic modeled results along with well-log lithology data to infer the subsurface distribution of basin fill within the subbasins. Hydrogeologic units (HGUs) are delineated within the subbasins on the basis of the inferred lithology of saturated basin fill. We used the extent and size of HGUs to estimate groundwater storage to depths of 400 meters ( $\mathrm{m} ; 1,312$ feet, $\mathrm{ft}$ ) below land surface (bls).

The basin geometry model for the Hualapai Valley basin consists of three subbasins: the Kingman, Hualapai, and southern Gregg subbasins. In the Kingman subbasin, which is estimated to be $1,200 \mathrm{~m}(3,937 \mathrm{ft})$ deep, saturated basin fill consists of a mixture of fine- to coarse-grained sedimentary deposits. The Hualapai subbasin, which is the largest of the subbasins, contains a thick halite body from about $400 \mathrm{~m}$ to about 4,300 m (14,107 ft) bls. Saturated basin fill overlying the salt body consists predominately of fine-grained older playa deposits. In the southern Gregg subbasin, which is estimated to be $1,400 \mathrm{~m}(4,593 \mathrm{ft})$ deep, saturated basin fill is interpreted to consist primarily of fine- to coarse-grained sedimentary deposits. Groundwater storage to $400 \mathrm{~m}$ bls in the Hualapai Valley basin is estimated to be 14.1 cubic kilometers $\left(\mathrm{km}^{3} ; 11.4\right.$ million acre-feet).

The basin geometry model for the Detrital Valley basin consists of three subbasins: northern Detrital, central Detrital, and southern Detrital subbasins. The northern and central Detrital subbasins are characterized by a predominance of playa evaporite and fine-grained clastic deposits; evaporite deposits in the northern Detrital subbasin include halite. The northern Detrital subbasin is estimated to be $600 \mathrm{~m}(1,968 \mathrm{ft})$ deep and the middle Detrital subbasin is estimated to be $700 \mathrm{~m}$ $(2,296 \mathrm{ft})$ deep. The southern Detrital subbasin, which is estimated to be $1,500 \mathrm{~m}(4,921 \mathrm{ft})$ deep, is characterized by a mixture of fine- to coarse-grained basin fill deposits. Groundwater storage to $400 \mathrm{~m}$ bls in the Detrital Valley basin is estimated to be $9.8 \mathrm{~km}^{3}$ (7.9 million acre-feet).

The basin geometry model for the Sacramento Valley basin consists of three subbasins: the Chloride, Golden Valley, and Dutch Flat subbasins. The Chloride subbasin, which is estimated to be $900 \mathrm{~m}(2,952 \mathrm{ft})$ deep, is characterized by fine- to coarse-grained basin fill deposits. In the Golden Valley subbasin, which is elongated north-south, and is estimated to be $1,300 \mathrm{~m}(4,265 \mathrm{ft})$ deep, basin fill includes fine-grained sedimentary deposits overlain by coarse-grained sedimentary deposits in much of the subbasin. The Dutch Flat subbasin is estimated to be $2,600 \mathrm{~m}(8,530 \mathrm{ft})$ deep, and well-log lithologic data suggest that the basin fill consists of interlayers of gravel, sand, and clay. Groundwater storage to $400 \mathrm{~m}$ bls in the Sacramento Valley basin is estimated to be $35.1 \mathrm{~km}^{3}(28.4$ million acre-feet).

\section{Introduction}

Basin fill aquifers are the primary source of groundwater in the Hualapai Valley, Detrital Valley, and Sacramento Valley basins of northwest Arizona for domestic, mining, and industrial use (fig. 1). Groundwater declines are not occurring in most areas (Anning and others, 2007), although in some areas extensive groundwater fluctuations were observed between 1943 and 2006, and in other areas there were steady groundwater declines (Anning and others, 2007). As in many parts of the western United States, population growth in these valleys has been substantial. For example, from 2000 to 2010 the population of Kingman grew from 20,069 to 28,068 - an increase of 39.9 percent (U.S. Census Bureau, 2011) - and the population of Mohave County increased by 29.1 percent. Recently proposed developments for approximately 200,000 new houses and condominiums in all three basins, and groundwater use for alternative energy in a proposed solar corridor 


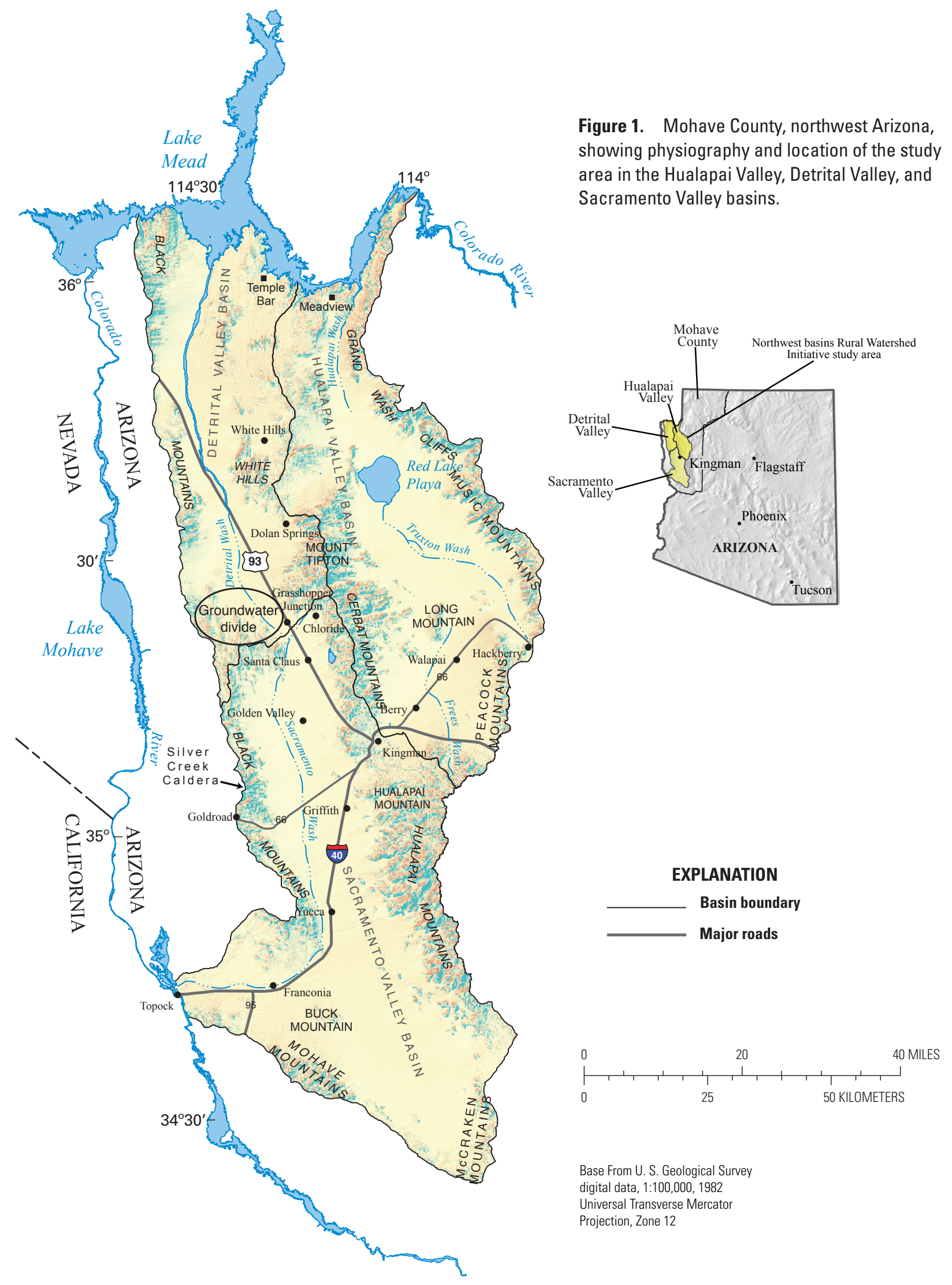


have raised concerns about groundwater availability and storage from water managers, Mohave County, and the Arizona Department of Water Resources (ADWR; Kevin Davidson, Planner II, written commun., 2008; Las Vegas Review-Journal, http://www.lvrj.com/business/44775192.html).

The ADWR recognized the need to conduct a comprehensive scientific study of the basin fill aquifers to help growing communities within Mohave County sustainably manage their groundwater resources. In 2005, the U.S. Geological Survey (USGS), in cooperation with the ADWR, began a regional study of the Hualapai Valley, Detrital Valley, and Sacramento Valley basins in northwestern Arizona to characterize the hydrogeology and estimate groundwater storage in the upper $400 \mathrm{~m}$ of the valley basins. That study is part of the Rural Watershed Initiative (RWI), a program established by the State of Arizona that is managed by the ADWR. The RWI focuses on addressing water-supply issues in rural areas and encourages participation from local partnerships. RWI projects and publications describing the hydrogeology have been completed in the middle San Pedro, and upper and middle Verde River watersheds, on the Coconino Plateau, and in the Mogollon Highlands (Parker and others, 2005; Blasch and others 2006; Bills and others, 2007; Dickinson and others, 2010).

\section{Purpose and Scope}

The purpose of this report is to achieve a better understanding of the hydrogeologic framework of, and to estimate groundwater storage in the Hualapai Valley, Detrital Valley, and Sacramento Valley basins of northwestern Arizona. A hydrogeologic framework is a conceptual model that describes how the bedrock and basin fill influence the movement, storage, and quality of groundwater within each valley basin.

The scope of the present study involved analysis of recent and historical geophysical, water-level, and geologic data to characterize the alluvial deposits within the Hualapai Valley, Detrital Valley, and Sacramento Valley basins. Subsurface lithology was inferred from airborne transient electromagnetic (TEM) resistivity profiles to a depth of 400 meters (m) below land surface (bls), and a basin geometry model was constructed from relative gravity data used to characterize the basin geometry and overlying basin fill. Revised geologic data (Beard and others, 2011) provide a more detailed map of the surface geology and structure. Water-level data (Anning and others, 2007) were used to define the top of the groundwater surface. Hydrogeologic units (HGUs) of saturated fine-grained, coarse-grained, or undifferentiated basin fill from inferred lithology were used to estimate groundwater storage to $400 \mathrm{~m}$ bls, which correlates to the depth of the resistivity profiles.

\section{Study Area}

The Hualapai Valley, Detrital Valley, and Sacramento Valley basins are broad, intermountain desert basins in Mohave
County, northwestern Arizona, that are home to residents in Kingman, Golden Valley, Meadview, Dolan Springs, and several other rural communities (fig. 1). The spatial extent of these valley basins is outlined by the groundwater basin boundaries defined by the ADWR. Valley-floor elevations range from about $150 \mathrm{~m}$ above mean sea level at the mouth of Sacramento Wash near Topock to about 1,060 m above mean sea level near Kingman. Mountain crests rise to 2,179 m above mean sea level at Mount Tipton in the Cerbat Mountains and to 2,565 $\mathrm{m}$ above mean sea level at Hualapai Mountain. All surface drainages in the three valley basins are ephemeral, flowing only during significant precipitation events.

The climate of the valley basins is semiarid to arid with hot summers and mild winters. Maximum daily temperatures on the valley floors typically range from 32 degrees Celcius $\left({ }^{\circ} \mathrm{C}\right)$ to $43.3^{\circ} \mathrm{C}$ during the summer, and from 10 to $21^{\circ} \mathrm{C}$ during the winter (Western Regional Climate Center, 2005). Annual precipitation on the valley floors ranges from about 12.7 to 20.3 centimeters (cm); (fig. 2; Western Regional Climate Center, 2005). The valley floors generally are covered with sparse desert vegetation, owing to the hot temperatures and limited precipitation. Shrubs and trees cover mountain slopes and peaks in the higher elevations, where temperatures are cooler and precipitation is greater. Annual precipitation in the mountains ranges from about 25.7 to $38.1 \mathrm{~cm}$. Groundwater recharge primarily occurs along the mountain fronts, and groundwater flows from those areas toward the center of the valley basins and then along the basin axis to where it discharges at the north end of the Hualapai Valley and Detrital Valley basins into Lake Mead, or at the southwestern edge of Sacramento Valley basin into the Colorado River (Anning and others, 2007).

The Hualapai Valley basin comprises an area of about 2,000 square kilometers $\left(\mathrm{km}^{2}\right)$ and is bordered to the east by the Music and Peacock Mountains and the Grand Wash Cliffs, to the south by the Hualapai Mountains, to the west by the Cerbat Mountains and White Hills, and to the north by Lake Mead (fig. 1). The city of Kingman, which is located in the southwestern part of the Hualapai Valley basin and the northeastern part of the Sacramento Valley basin, relies completely on groundwater from the Hualapai Valley basin. The floor of the Hualapai Valley basin generally slopes north, and groundwater discharges into Lake Mead (Remick, 1981; Anning and others, 2007). Surface-water drainage in the Hualapai Valley basin is mostly internal. Truxton Wash is the principal ephemeral stream in the area and storm runoff events during the spring and summer drain into Red Lake playa. Hualapai Wash has ephemeral flows north of Red Lake and drains into Lake Mead. Smaller ephemeral streams flow into the valley basin from the mountains during storm runoff events in spring and summer, but most of the runoff is lost to evaporation and does not contribute to the larger washes (Remick, 1981).

The Detrital Valley basin comprises an area of about $1,400 \mathrm{~km}^{2}$ and is bordered to the east by the White Hills and Cerbat Mountains, to the west by the Black Mountains, to the north by Lake Mead, and to the south by a topographic divide separating it from Sacramento Valley basin (fig. 1). 


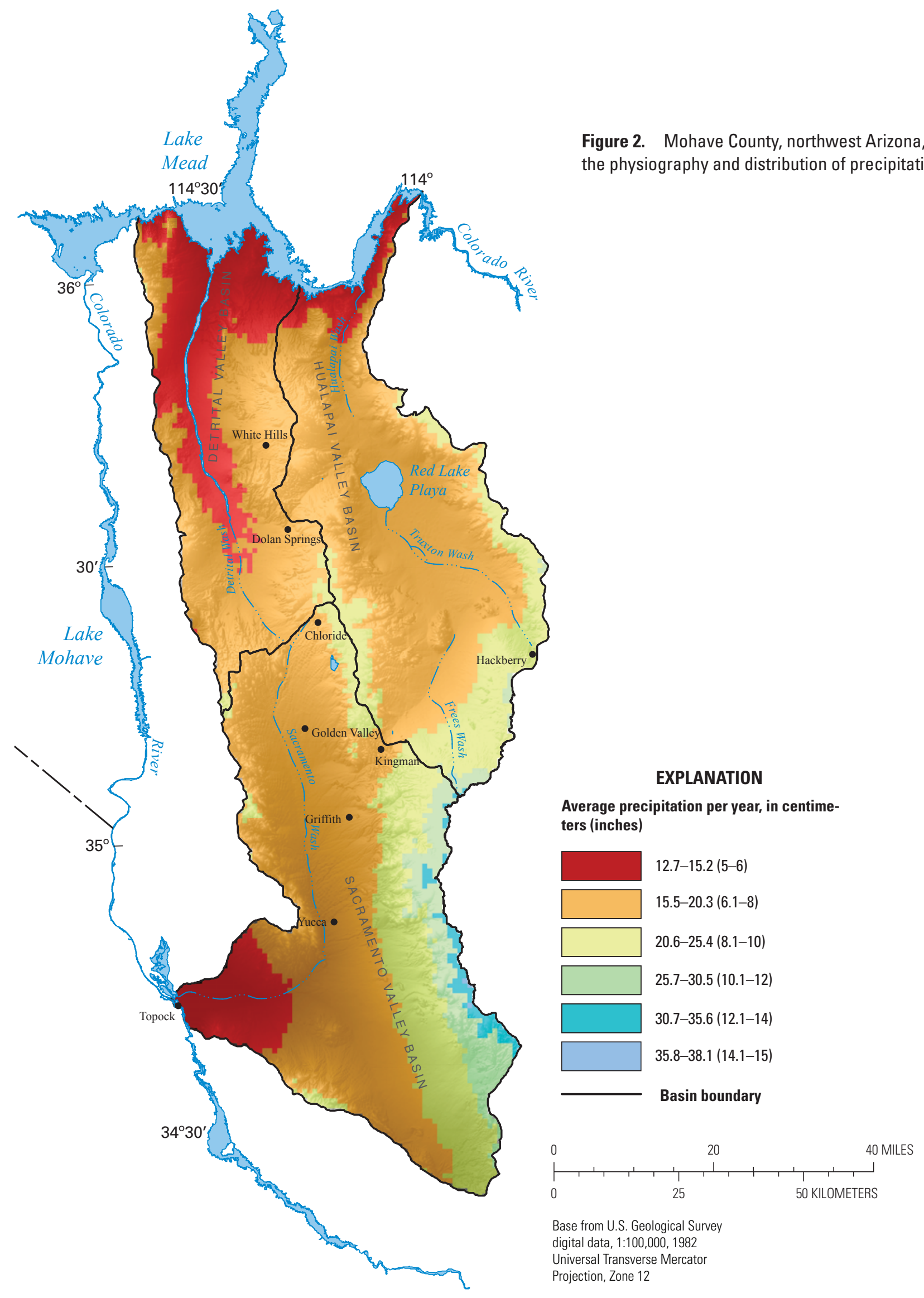


The towns of Temple Bar, Dolan Springs, White Hills, and Grasshopper Junction, located at the base of the White Hills and Cerbat Mountains, are the primary water users in the area. The floor of Detrital Valley basin generally slopes to the north and groundwater drains into Lake Mead (Anning and others, 2007). Detrital Wash is the largest ephemeral stream in the area and flows northward into Lake Mead.

The Sacramento Valley basin comprises an area of about 2,600 $\mathrm{km}^{2}$, bounded by the Cerbat and Hualapai Mountains to the east, by the Mohave and McCracken Mountains to the south, and by the Black Mountains to the west. The towns of Golden Valley, Chloride, Santa Claus, Harris, Griffith, and Topock are the primary water users in the basin. Open-pit copper, molybdenum, and silver mining in Golden Valley have also been large water users in the past. Sacramento Wash, the main ephemeral stream, originates north of Golden Valley, flows from north to south, and discharges into the Colorado River at Topock. Smaller ephemeral streams originating in the mountains flow into Sacramento Wash. The valley floor of the northern and central parts of the Sacramento Valley basin slopes south, and groundwater drains from the north into the Colorado River near Topock. The southern part of the Sacramento Valley basin slopes north or west and surface-water drains northward into Sacramento Wash or westward to the Colorado River (fig. 1).

\section{Previous Investigations}

In 1964, the USGS, in cooperation with the Arizona State Land Department, compiled data on the geology and water resources of the Hualapai and Sacramento Valleys (Gillespie and others, 1966). Using data from a study completed in 1966, Gillespie and Bentley (1971) indicated that the older alluvium and younger volcanic rocks are important aquifers in the Hualapai and Sacramento Valleys. From 1981 to 1991, the ADWR completed a series of studies on groundwater conditions and water quality in the Hualapai Valley, Detrital Valley, and Sacramento Valley basins (Remick, 1981; Dillenberg, 1987; Rascona, 1991). Anning and others (2007) completed a study of groundwater occurrence and movement of groundwater in 2006 and water-level changes within the Hualapai Valley, Detrital Valley, and Sacramento Valley basins. Langenheim and others (2010) investigated gravity and magnetic anomalies in the northern Colorado River extensional corridor and the Lake Mead area. Local gravity studies were previously completed in the Hualapai Valley, Detrital Valley, and Sacramento Valley basins by the ADWR (Mason and others, 2007; Conway and Ivanich, 2008; Ivanich and Conway, 2009).

\section{Acknowledgments}

We thank the many landowners in the Hualapai Valley, Detrital Valley, and Sacramento Valley basins that permitted land access for the purpose of acquiring data. This study would lack essential data without their help and support. We are grateful to Leslie Graser, Bill Remick, Tom Whitmer, John Fortune, Brian Conway, and Paul A. Ivanich, formerly and presently of the ADWR, for their technical guidance throughout this study. We also thank our USGS colleagues Marilyn Flynn, Jamie P. Macy, Donald R. Pool, Jesse Dickinson, Tracey Felger, and Zachary Anderson for providing scientific and technical expertise.

\section{Approach}

The approach of this study was first to identify, acquire, and compile the geologic, geophysical, and water-level datasets needed to conceptualize the hydrogeologic framework of the Hualapai Valley, Detrital Valley, and Sacramento Valley basins. These same datasets and the conceptual understanding provided by the hydrogeologic framework were then used to estimate groundwater storage. The geologic maps (Beard and others, 2011) and cross sections compiled and synthesized for this study, as well-log and lithologic data, formed a foundation of geologic information for constructing the hydrogeologic framework. Results of this analysis are included in the section below entitled "Hydrogeologic Framework Components."

Geophysical surveys of relative gravity that included data collected by the ADWR in 2006 were used to construct basin geometry models that described basin fill thickness and defined subbasins. Geophysical surveys of airborne TEM data, which were collected as part of this study to provide lithologic information along selected basinwide transects, provided information to a depth of about $400 \mathrm{~m}$ bls. Geologic information from maps and well logs helped constrain both the basin geometry model and lithologic interpretations of the airborne TEM data. Hydrologic maps by Anning and others (2007) and well logs provided water-level data for each basin and helped define where basin fill is saturated or unsaturated. Results of this data collection and compilation are discussed below.

The groundwater storage model used information from the hydrogeologic framework for each valley basin to a depth of $400 \mathrm{~m}$ bls. Basin fill lithologic units were delineated in the hydrogeologic framework and were binned into one of four generalized hydrogeologic units (HGUs), which were defined for the purpose of estimating groundwater storage and constructing groundwater-flow models. Information from the hydrogeologic framework defined the lateral and vertical extents of the HGUs, and with estimates of specific yields for each HGU, groundwater storage estimates were determined. The results of this effort are reported in the section entitled "Groundwater Storage."

\section{Hydrogeologic Framework Components}

The hydrogeologic framework for the Hualapai Valley, Detrital Valley, and Sacramento Valley basins was constructed through analysis of new and existing geologic, geophysical, and water-level information. An extensive literature search 
of published data and information was used to develop initial conceptual models and identify information needs. Preexisting data and information are available from the State of Arizona geologic map (Richard and others, 2000) and from other similar hydrogeologic studies in other parts of Arizona (Brown and others, 1966; Freethey, 1982; Pool and Coes, 1999; Coes and Pool, 2007; Pool and Dickinson, 2007; Dickinson and others, 2010).

Components required to construct the hydrogeologic framework included geophysical data for modeling subsurface geology that affects groundwater flow, depth to bedrock and thickness of saturated basin fill, and extent and depth of silt, clay, and evaporite layers within coarse-grained sedimentary deposits. To address these data and information needs, new data collection included compilation of previous geologic mapping (Beard and others, 2011), relative gravity surveys (Mason and others, 2007; Conway and Ivanich, 2008; Ivanich and Conway, 2009), airborne TEM resistivity profiles, and examination of lithologic information from well logs.

A 1:250,000-scale geologic map covering the Detrital Valley, Hualapai Valley, and Sacramento Valley basins of northwestern Arizona was published by Beard and others (2011) for the purpose of improving understanding of the geology and hydrogeology of the study area (fig. 3). Their map, which was compiled from existing geologic mapping augmented by digital photogeologic reconnaissance mapping, provides significantly more detailed geology than the 1:1,000,000-scale geologic map of Arizona (Richards and others, 2000) with regard to the accuracy of unit contacts, number, type, and location of faults, and details of Neogene and Quaternary deposits. It also provides a detailed summary of the geologic units, setting, and history of the Hualapai Valley, Detrital Valley, and Sacramento Valley basins. The geologic units and geologic map from that report are generalized in figures 3 and 4 and briefly summarized below.

Geophysical data used for mapping subsurface lithology and structure included relative gravity measurements and airborne TEM resistivity surveys. Relative gravity measurements were used to estimate depth to the top of bedrock, thickness of basin fill, and to construct a basin geometry model based on differences in the densities of bedrock and basin fill (Telford and others, 1976). The basin geometry model presented in this study delineates nine subbasins in the three valley basins, discussed in more detail in the subsection below entitled "Basin Geometry Model." The geometry of the subbasins is important because it influences the vertical and lateral distribution of basin fill determining groundwater storage.

An electrical current can flow more easily through saturated fine- and coarse-grained basin fill and (or) evaporites versus unsaturated fine- and coarse-grained basin fill and (or) evaporites. Electrical-resistivity data obtained from airborne TEM were used to delineate areas of crystalline and volcanic bedrock, distinguish saturated silt and clay from saturated sand and gravel, and identify the lateral extent of thick sequences of gypsum/anhydrite and halite in the northern parts of the Hualapai Valley and Detrital Valley basins. Well-log lithologic data and TEM resistivity profiles of the valley floors, presented in the subsections below entitled "Well-Log Lithologic Data" and "Interpreted Resistivity Profiles" respectively, were used to help classify the basin fill into lithologic units.

\section{Geologic Setting}

The study area (fig. 1) is mostly in the Basin and Range Physiographic Province (Fenneman, 1931), which was formed by extensional faulting during the Miocene. The study area is underlain by crystalline Proterozoic rocks, either exposed at the surface or overlain by thin to thick sequences of Miocene volcanic and sedimentary rocks. Lower Paleozoic strata are exposed only along the Colorado Plateau's margin at the east edge of the study area. The fault-bounded ranges are separated by extensional basins that underlie the three valley basins and form the subbasins identified in the basin geometry section discussed later in this report. Pliocene through Holocene surficial deposits blanket the slopes and surfaces of the valleys. This summary provides a broad overview of the study area's geology, whereas Beard and others (2011) discuss in more detail the regional geologic history and provide descriptions of the geologic structures and formations.

The map by Beard and others (2011) provides an understanding of the processes and formation of geologic structures, depositional environments, and associated sedimentary sequences in the study area. Such an understanding is needed for spatial extrapolation of lithology from areas with data and known conditions into areas that lack such data and require estimation of the sedimentary lithology. Beard and others's (2011) results are summarized below in the next two parts of this subsection.

\section{Regional Geologic History}

Proterozoic crystalline basement rocks include metamorphic gneiss and schist deformed about 1.73-1.68 Ga and later intruded by granite about $1.4 \mathrm{Ga}$ (table 1). Paleozoic sedimentary rocks were deposited on an unconformity in the basement rocks. During late Cretaceous and Paleocene (Laramide) time, the study area was locally intruded by late Cretaceous plutons and uplifted, exposing basement rocks in the core of the uplift. Post-Laramide erosion removed Paleozoic and Mesozoic sedimentary deposits off the uplift (Bohannon, 1984) and created a beveled erosional surface cut on lower Paleozoic rocks of the western Colorado Plateau's margin. The erosion was accompanied by the formation of large paleovalleys that drained northeastward off the uplift and onto the Colorado Plateau (Young, 2001), including a paleovalley between the Cerbat and Hualapai Mountains (Beard and others, 2011) where the city of Kingman is located (fig. 3).

Cenozoic geologic processes in the study area began with volcanism and plutonism at about $20 \mathrm{Ma}$, followed by crustal extension and continued volcanism and plutonism (fig. 4; Faulds, 1995). The main extensional event started about $16 \mathrm{Ma}$ 
Table 1. Geologic units and correlation to lithologic description and depositional setting in the Hualapai Valley, Detrital Valley, and Sacramento Valley basins, Mohave County, Arizona.

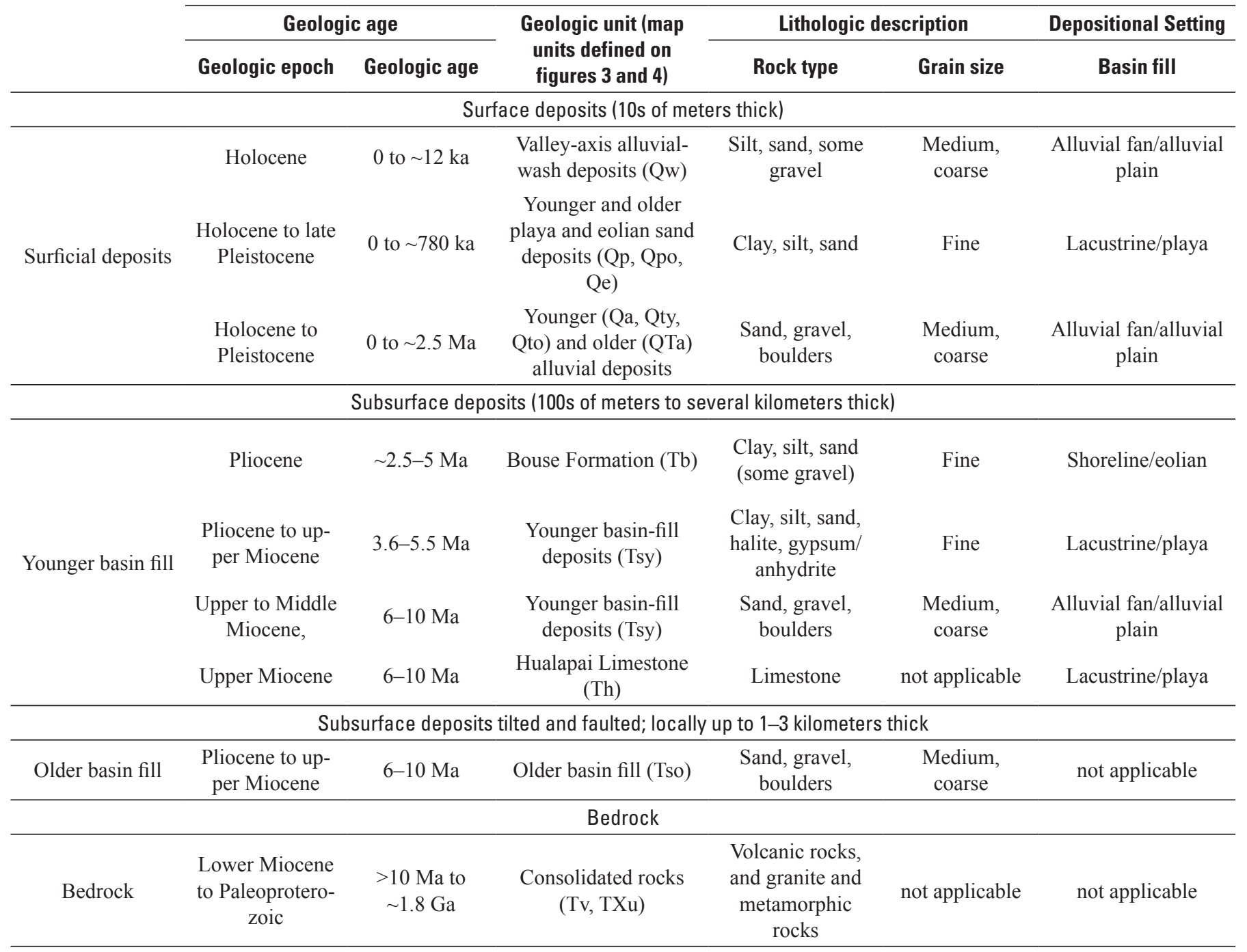




\section{EXPLANATION}

Younger surficial deposits (Pleistocene and Holocene)

Qw Valley-axial wash alluvium
Qa Younger alluvial-fan deposits

Qe Eolian sand

Qp Playa deposits

Qpo Older playa deposits

Qty Younger Truxton Wash alluvial-fan deposits

Qto Older Truxton Wash alluvial-fan deposits

\section{Older surficial deposits (Pliocene and Pleistocene)}

QTa Older alluvial-fan deposits

Younger basin-fill deposits (late Miocene)

Tsy Clastic deposits and evaporite

\begin{tabular}{|c|c|}
\hline $\mathrm{Tb}$ & Bouse Formation \\
\hline Th & Huala \\
\hline
\end{tabular}

Older basin-fill deposits (middle Miocene)

Tso Conglomerate, sandstone, and breccia

Volcanic rocks (middle and late Miocene)

Tv Mafic and felsic volcanic rocks and ash-flow tuff

\section{Sedimentary rocks (early Paleozoic)}

$\mathrm{PzU}$ Siliciclastic rocks and carbonate

Crystalline basement rocks

(Proterozoic, Cretaceous, and Miocene)

TXu Cretaceous and Tertiary granite

Proterozoic granite and gneiss

Water

Faults

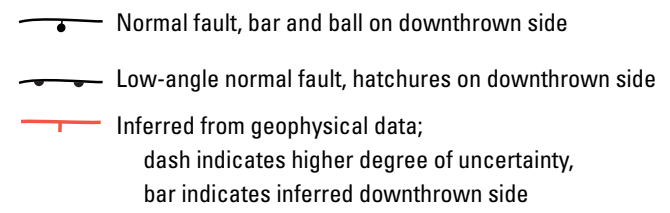

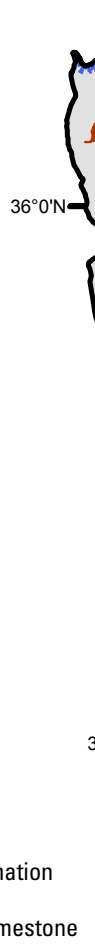
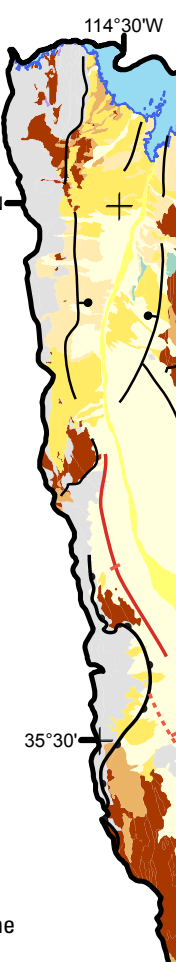
and peaked about 15 to $13 \mathrm{Ma}$; it affected most of the study area, from north of Goldroad (fig. 1) to Lake Mead and from Sacramento Wash southward, and resulted in highly tilted fault blocks bounded by north-northwest-striking faults. The extensional basins that formed during this event filled with middle Miocene volcanic rocks and older sedimentary deposits (fig. $4 A$ ). In the northern White Hills the basins are predominately filled with clastic deposits, and in the southwest White Hills and the Black Mountains the older basin fill is predominately volcanic rocks (Beard and others, 2011).

Later $(\sim 13-8 \mathrm{Ma})$ extensional faulting formed the subbasins, typically bounded by one or more northerly-striking normal faults that underlie the modern valleys (fig. $4 B$; Beard and others, 2011). These subbasins were internally drained and filled by the late Miocene sediment deposited in lacustrine/ playa, shoreline, alluvial-fan, and alluvial-plain settings. The lacustrine late Miocene Hualapai Limestone was deposited at the north end of Hualapai Valley, and deltaic sedimentary deposits of the late Miocene Bouse Formation were deposited along the Colorado River at the west end of the Sacramento Valley. In contrast to the older rocks, these deposits are mostly flat-lying or mildly tilted. Isolated late Miocene basalt flows overlie younger sedimentary deposits on the west side of the Detrital Valley and on the northeast flank of the Mohave Mountains. After integration of the Colorado River drainage ended interior basin deposition, the subbasins were overlapped and mostly buried by older Pliocene and Pleistocene surficial deposits, and Pleistocene and Holocene alluvial and playa deposits that form the smooth floors of the three valley basins (figs. 3, 4C). At the distal ends of the three valley basins, the younger sedimentary deposits, the Hualapai Limestone, and the Bouse Formation are eroded and exposed by tributaries that drain into Lake Mead and the Colorado River; these units are not exposed elsewhere in the valley basins.

\section{Geologic Description of the Valley Basins}

Bedrock, exposed in the mountain ranges and underlying Miocene sedimentary deposits in the three valley basins, is composed primarily of Proterozoic metamorphic and granitic rocks, locally intruded by small Late Cretaceous and Miocene plutonic rocks. Together, these rocks form a crystalline basement complex and are the lowermost barrier to movement of groundwater in the study area (Gillespie and Bentley, 1971). The crystalline rocks do not yield much water, except in highly weathered zones and along fractures.

In this study, we focus on the hydrogeology of the sedimentary deposits and overlying basin fill and so the volcanic rocks are included in the bedrock unit. Thick sequences of faulted middle Miocene mafic to felsic volcanic flows, vents, and domes are widely exposed in the White Hills and Black Mountains and probably underlie parts of the Detrital Valley and Sacramento Valley basins. In contrast, a thinner sequence of volcanic flows fills a paleovalley between the Cerbat and Hualapai Mountains near Kingman (fig. 3; Beard and others, 2011) and underlies the southern part of the Hualapai Valley basin.

The depositional history and resulting facies distributions of the Miocene sedimentary deposits and overlying basin fill are components of the hydrogeologic framework. The middle Miocene sedimentary deposits are commonly interlayered with volcanic rocks (fig. $4 A$ ), typically well consolidated, and are faulted and tilted. The volcanic rocks, which are exposed in the White Hills and locally in the Black Mountains (figs. 1, 3) probably underlie at least some parts of the valley basins; basin-fill rocks are mostly coarse-grained clastic units formed in alluvial fans mostly derived from fault scarps along the basin margins. Late Miocene sedimentary deposits include fine grained clastic and evaporite units deposited in lacustrine/ playa and fringing shoreline depositional settings (fig. 4B). Coarser-grained rocks within the younger sedimentary deposits were deposited in alluvial fans and on alluvial plains along the margins of the younger basins.

Unconsolidated Pliocene through Holocene alluvial-fan, alluvial-plain, valley-axis wash alluvial, and pediment deposits form a veneer on the basin fill in the subbasins and (or) mantle pedimented surfaces, mountain slopes, and cliffs (fig. $4 C$ ). Active and inactive Pleistocene through Holocene playa deposits form the floor of Red Lake playa in the Hualapai Valley basin (fig. $5 A$ ), and eolian deposits occur locally downwind (southeast) of the playa (fig. 3).

\section{Hualapai Valley Basin}

The Hualapai Valley basin is both rimmed by and underlain by mainly crystalline Proterozoic rock (Beard and others, 2011). Middle Miocene volcanic flows occur in the paleovalley near Kingman and extend eastward in the subsurface where they underlie Quaternary alluvial sedimentary deposits. The rocks include the Peach Spring Tuff (18.5 Ma; Nielsen and others, 1990), a moderately welded ash-flow tuff. The volcanic rocks transmit some water in the fractures and interbeds of tuffs but are generally too fine grained to yield substantial volumes of water to wells (Gillespie and Bentley, 1971).

The late Miocene Hualapai Limestone overlies the Proterozoic rocks in a buttress unconformity on the northwestern edge of Hualapai Valley basin and is interbedded with locally derived sedimentary deposits along the northeast edge of the valley basin (figs. 1, 3; Beard and others, 2011). The limestone typically yields water with an elevated content of total dissolved solids (Towne and Rowe, 2007).

The deepest part of the Hualapai Valley basin is an extensional basin that underlies Red Lake playa, formed by large down-to-the west displacement on the southern section of the Grand Wash Fault (fig. 3). The basin fill consists of both early and late Miocene sedimentary deposits, overlain by Pliocene through Holocene primarily unconsolidated surficial deposits. The basin fill ranges in thickness from 100 to 4,300 $\mathrm{m}$ in the center of the extensional basin. The upper $600 \mathrm{~m}$ in the extensional basin includes Pliocene through Holocene clay and siltstone, with lesser amounts of gypsum, anhydrite, 


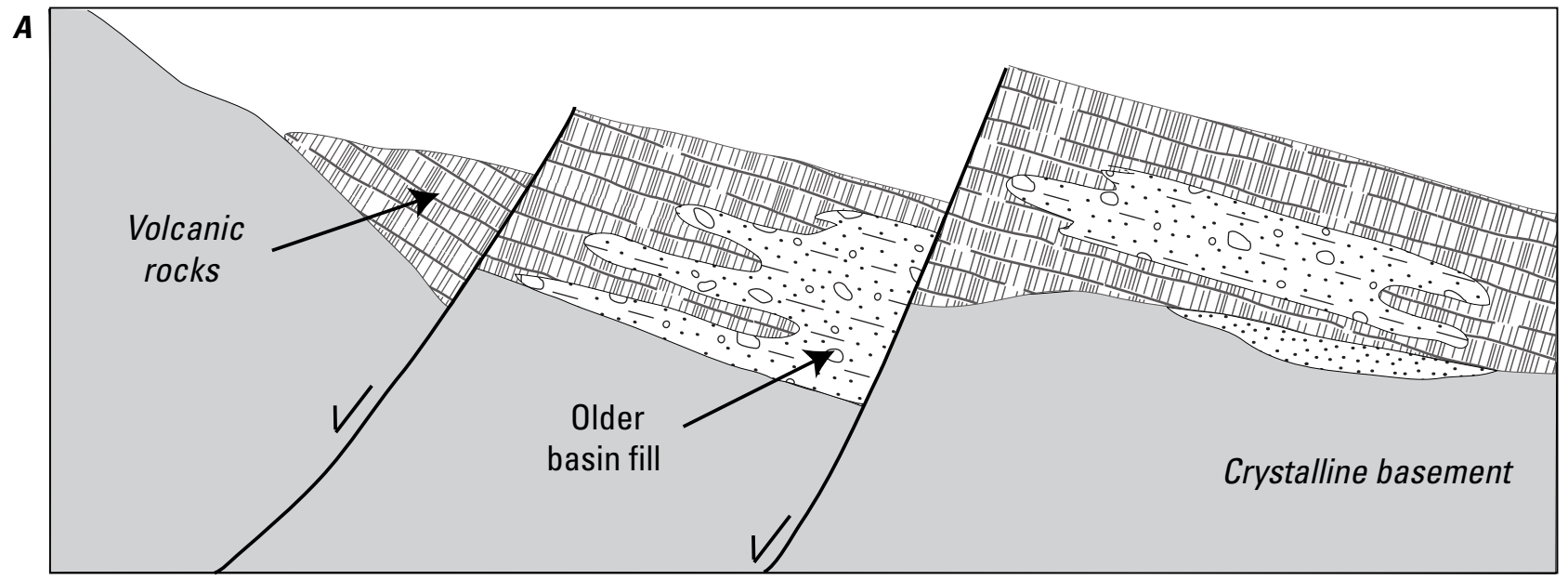

$\boldsymbol{B}$

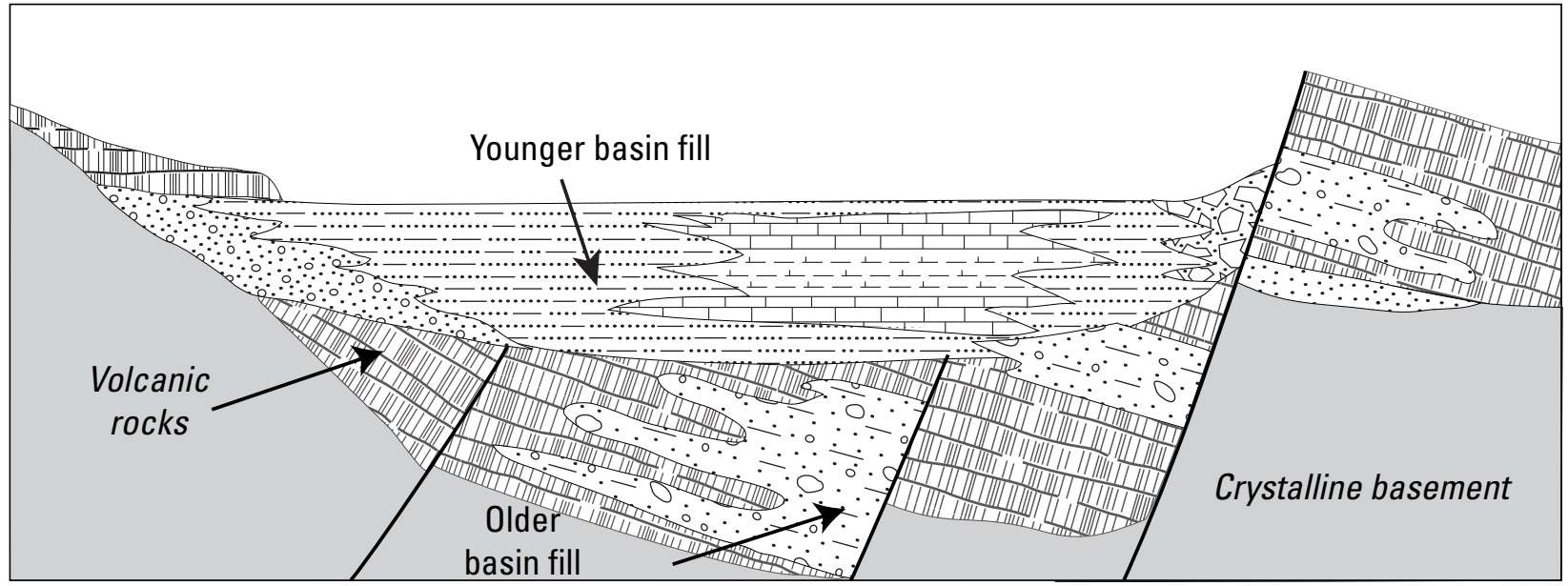

C

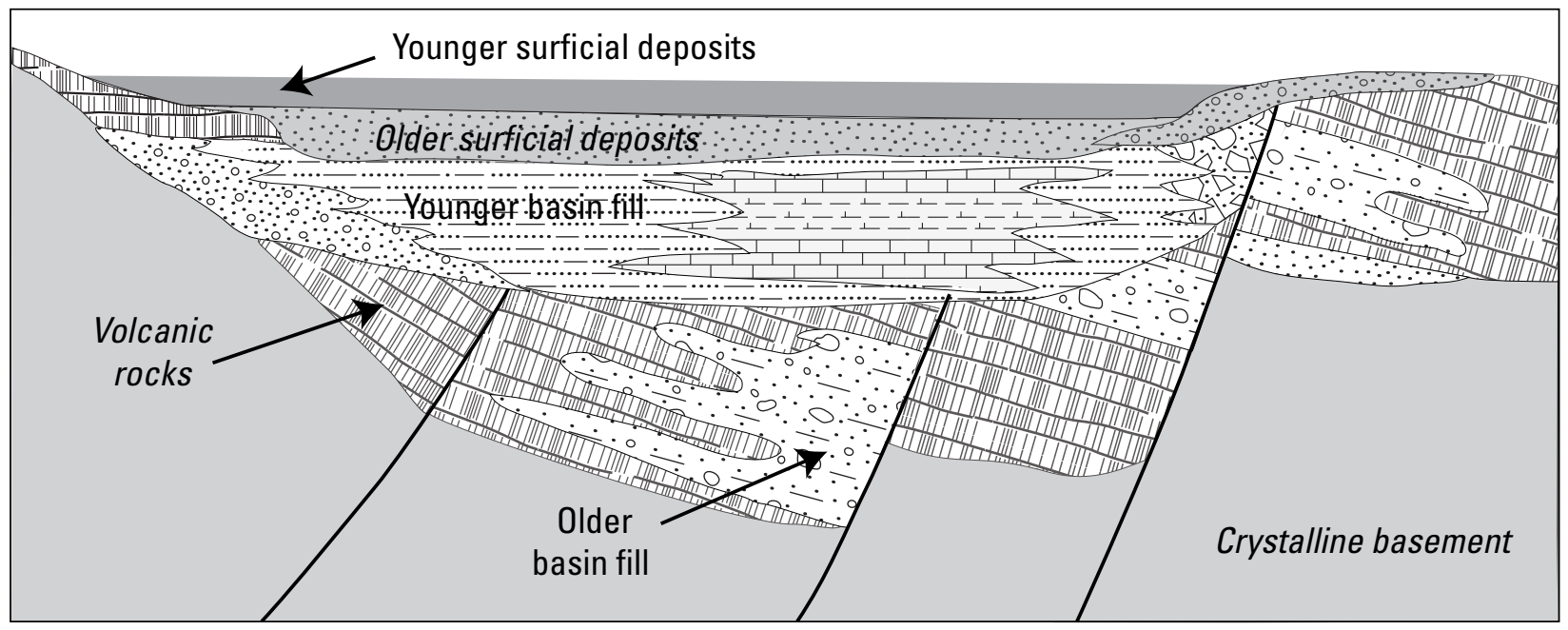

(Modified from Beard and others, 2011)

Figure 4. Schematic cross-sections showing extensional-basin evolution, structural and stratigraphic relations between older and younger basin fill, volcanic rocks, and older and younger surficial deposits. $A$, Extension from about 16 to $13 \mathrm{Ma}$ forms half-graben basins that include coarse-grained alluvial conglomerate and breccia sheets of intermediate-age sedimentary rocks shed from active faults and interlayered with volcanic flows. $B$, Continued Miocene faulting (13 to $\sim 8 \mathrm{Ma}$ ) forms subbasins filled by mostly fine-grained basin fill. $C$, Late Pliocene and Quaternary surficial deposits blanket surface of subbasins within valley basin. 

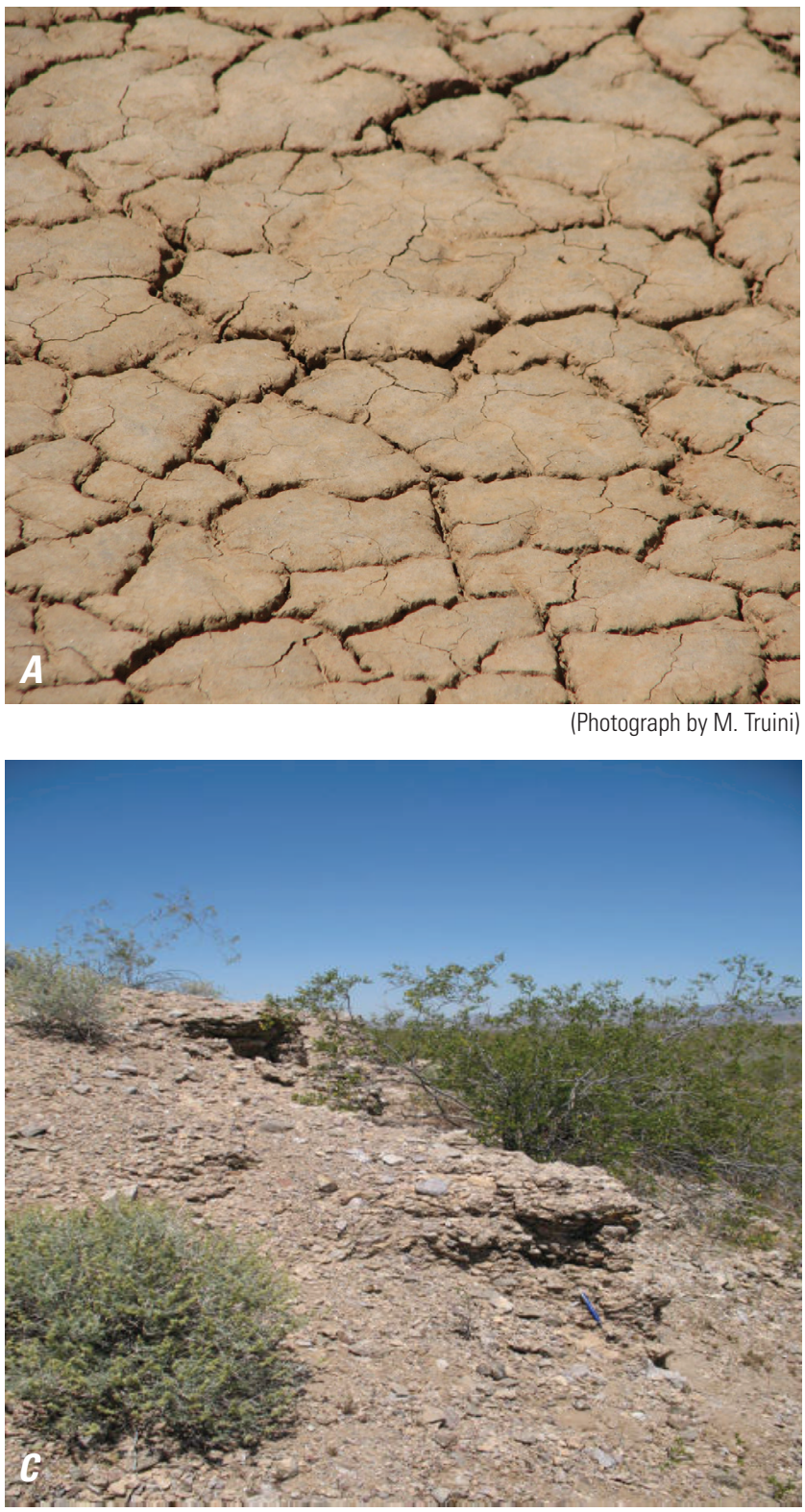

(Photograph by L.S. Beard)

and conglomerate deposited in a playa environment. These deposits overlay as much as 2,500 $\mathrm{m}$ of middle to late Miocene halite, shale, and minor gypsum/anhydrite sedimentary deposits that interfinger laterally in the subsurface with coarsegrained conglomerate derived from the Grand Wash Cliffs (Faulds and others, 1997). The halite deposits are most likely underlain by volcanic rocks and lower Paleozoic strata, downfaulted into the basin along the Grand Wash Fault (Faulds and others, 1997). Truxton Wash, Frees Wash, and Hualapai Wash contribute Holocene alluvial deposits (table 1), consisting mainly of loose, fine-grained basin fill, including mud, silt, sand, and minor gravel (Beard and others, 2011).

\section{Detrital Valley Basin}

Tilted and faulted middle Miocene volcanic rocks and older sedimentary deposits overlie crystalline bedrock in the

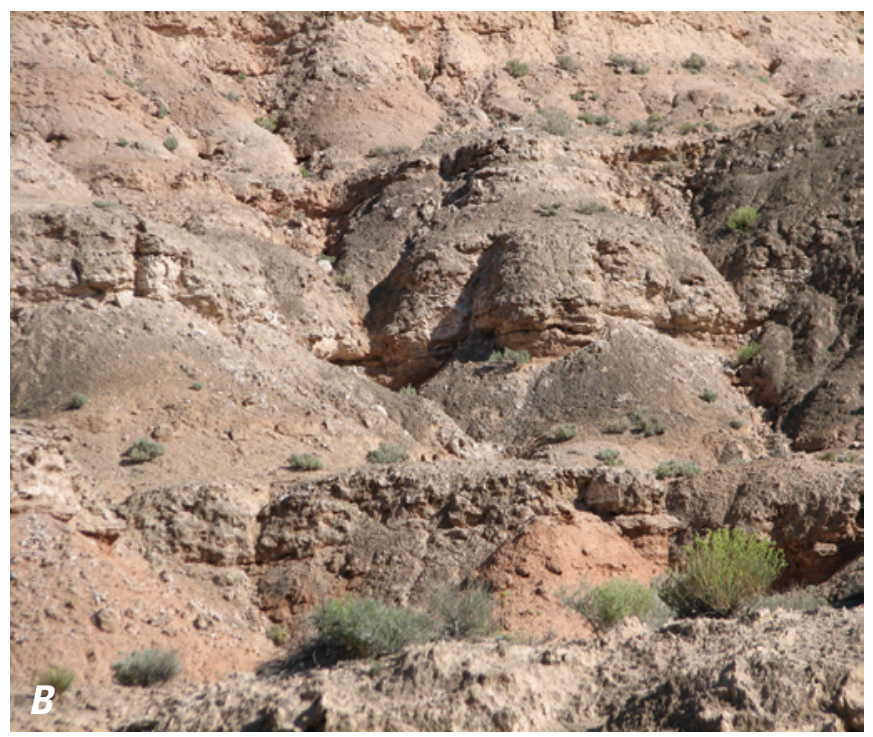

(Photograph by M. Truini)

Figure 5. Photographs show exposed sedimentary deposits of active playa deposits in Red Lake playa, Hualapai Valley basin $(A)$, interbedded fine-grained basin fill and gypsum evaporite deposits in the northern Detrital Valley subbasin $(B)$, and alluvial basin fill on Buck Mountain $(C)$, in the southern part of the Sacramento Valley basin, Mohave County, northwestern Arizona.

central and northern Black Mountains and western White Hills, and probably occur in the subsurface of the Detrital Valley basin. The Hualapai Limestone is exposed along the north side of the White Hills into the east edge of the northern part of the valley (fig. 3), but has not been penetrated by wells in the subsurface (Beard and others, 2011).

The tilted Miocene rocks in the subsurface of the Detrital Valley basin are overlain by late Miocene sedimentary deposits (Beard and others, 2011). The central and northern parts of the valley basin contain evaporite (fig. $5 B$ ) and fine-grained clastic deposits younger basin fill in the subsurface. Wells in the southern part of the valley basin penetrate clastic deposits in the upper 300 to $400 \mathrm{~m}$, but the lithology of the deeper part of this area in the valley basin is unknown (Beard and others, 2011). Pliocene through Holocene surficial alluvial fan and wash deposits unconformably overlie the younger and older basin fill deposits (Beard and others, 
2011). A subsurface bedrock bench, about 200 to $600 \mathrm{~m}$ bls, which extends $10 \mathrm{~km}$ westward of Dolan Springs (fig. 1), is overlain by alluvial-fan deposits.

\section{Sacramento Valley Basin}

Crystalline bedrock underlies the Cerbat and Hualapai Mountains and is locally exposed at the base of the volcanic section in the Black Mountains. Middle Miocene volcanic rocks in the Black Mountains range in thickness from several hundred meters to as much as 2 to $3 \mathrm{~km}$. The Peach Spring Tuff is exposed in the Black Mountains on the west-central side of the Sacramento Valley basin and in the paleovalley at Kingman, and most likely occurs in the subsurface between the two areas (Beard and others, 2011). The east side of Sacramento Valley basin is a pediment formed on shallow bedrock 8 to $10 \mathrm{~km}$ westward from the Hualapai Mountain. Southwest of
Kingman, the pediment is formed mostly on Proterozoic crystalline rocks but locally overlies volcanic rocks. The volcanic and crystalline rocks are exposed in isolated hills surrounded by alluvial deposits on the pediment surface (Beard and others, 2011).

The northern part of the Sacramento Valley basin is underlain by north-south elongate fault-controlled extensional basins, filled with younger basin fill consisting of alternating fine- and coarse-grained clastic deposits (Beard and others, 2011). The Bouse Formation (Metzger and Loeltz, 1973) occurs in the subsurface along Sacramento Wash near Topock. Other sedimentary deposits include fine-grained clastic younger basin fill that interfingers laterally with and are overlain by the alluvial deposits veneering the pediment surface along the east side and west sides of the valley basin (fig. $5 C$ ) and valley-axial wash deposits along the main washes. Unlike in the Hualapai Valley and Detrital Valley basins, no

Table 2. Generalized grouping of lithology from well logs.

\section{Grouping of lithology from well logs}

Simplified lithologic grouping for wells used to interpret resisitivity and shown in figs. 6-24

\footnotetext{
Sedimentary deposits — coarse and fine grained — primarily cobbles and boulders, secondarily silt and clay

Sedimentary deposits — coarse and medium grained - primarily cobbles and boulders, secondarily sand and gravel
}

Sedimentary deposits — coarse-grained — generally cobbles and boulders

Sedimentary deposits - fine and coarse grained - primarily clays and silt, secondarily cobbles and boulders

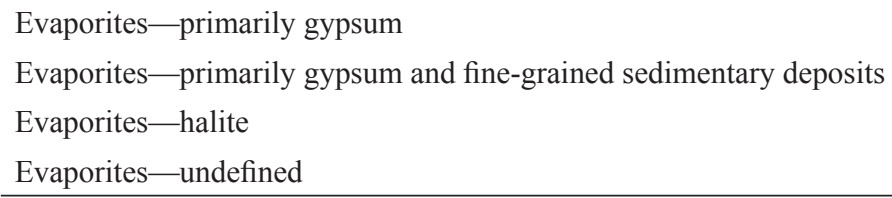

Sedimentary deposits - medium and coarse grained — primarily sand and gravel, secondarily cobbles and boulders

Sedimentary deposits - medium-grained - generally sand and gravel

Medium-grained sediment

Sedimentary deposits - medium and fine grained - primarily sand and gravel, secondarily clay and silt

Sedimentary deposits - fine and medium grained - primarily clay and silt, secondarily sand and gravel

Evaporite

Sedimentary deposits - fine-grained — generally silt and clay

\begin{tabular}{ll}
\hline Sedimentary deposits_clast size undifferentiated & Undifferentiated sediment \\
\hline Sedimentary deposits_-primarily coarse grained, indurated (conglomerate) & Indurated sediment \\
\hline Limestone — sometimes with siltstone, Cenozoic in age & Limestone \\
\hline Undifferentiated rock & Rock \\
\hline Crystalline-granite, gniess, and schist & Crystalline rocks \\
\hline
\end{tabular}

Volcanic - mafic - generally basalts and andesite

Volcaniclastic - volcanic conglomerate or breccia

Volcanic - felsic — generally rhyolite and dacite and welded tuff

Volcanic rocks

Volcanic-undifferentiated 
known evaporite deposits occur in Sacramento Valley basin. The unconsolidated clastic deposits yield groundwater with generally low contents of total dissolved solids (Towne and others, 2001).

\section{Well-Log Lithologic Data}

Well logs provided lithology data for ground truthing and spatially extrapolating interpretations of the gravity and TEM data. Lithologies interpreted from drilling logs for wells that penetrate the sedimentary deposits in the Hualapai Valley, Detrital Valley, and Sacramento Valley basins were coded and entered into a Microsoft Access database that included lithologic data from wells in the USGS Groundwater Systems Information (GWSI) database and the ADWR wells database (Wells-55). Wells in the GWSI and Wells-55 databases were primarily used to verify our interpretation of the resistivity profiles and the shallower part of the gravity basin geometry model. Because the locations of wells in the ADWR database are defined by using the land net $1 / 4,1 / 4,1 / 4$ and so are generally not as accurate as those of wells in the GWSI database, which uses Global Positioning System (GPS) locations, ADWR data were used only to fill in generalized data gaps. Wells penetrating bedrock (crystalline and volcanic) are mostly located along the periphery of the subbasins (fig. 6). The well log descriptions were divided into broad categories (table 2). Generally clastic sedimentary deposits were categorized on the basis of grain-size, whether unconsolidated or consolidated, and where possible, evaporite units were identified separately. Bedrock was categorized as either crystalline or volcanic. Where the sedimentary deposits or bedrock was uninterpretable, it was classified as undifferentiated basin fill or simply as rocks.

The Hualapai Valley basin contains 1,439 wells with lithologic data, of which 669 are in the USGS GWSI and ADWR base data (fig. 7). The deepest well, which reaches $795 \mathrm{~m}$ bls, is located south of Red Lake playa. A total of 42 were drilled into volcanic rocks, primarily in the southern part of the study area (fig. 1), and 60 wells are into crystalline rocks, primarily around the edges of the valley basins (fig. 6). Many of the wells drilled into volcanic rocks also penetrated the underlying crystalline rocks (fig. 6).

The Detrital Valley basin contains 511 wells with lithologic data, of which 319 are in the USGS GWSI and ADWR database (fig. 7). The deepest well reached $610 \mathrm{~m}$ bls, and is located east of the White Hills near the north end of the valley basin. A total of 25 wells were drilled into volcanic rocks and 15 wells into crystalline rocks. Most of the wells that penetrate the volcanic bedrock also penetrated in the underlying crystalline rocks (fig. 6).

The Sacramento Valley basin contains 1,387 wells with lithologic data, of which 558 are in the GWSI and ADWR database (fig. 7). The deepest well, which penetrates $756 \mathrm{~m}$ bls, is located near Santa Claus in the northern part of the valley basin. A total of 64 were drilled into volcanic rocks, primarily along the margins of the valley basin and subbasins, and 41 into crystalline rocks. Only a few of the wells drilled into the volcanic rocks penetrated the crystalline rocks (fig. 6).

\section{Basin Geometry Model}

Although several previous investigations have constructed basin geometry models for the study area (fig. 1), new gravity data and new methods of analysis allowed for construction of a new basin geometry model for the Hualapai Valley, Detrital Valley, and Sacramento Valley basins. Our model characterizes the basin geometry and thickness of overlying sedimentary deposits, helping to constrain the boundary between basin fill and bedrock in the hydrogeologic framework models and to define the geometry of structurally controlled subbasins within the larger valley basins.

\section{Previous Subsurface-Geometry Studies}

Bedrock depth and subsurface geometry in the Hualapai Valley, Detrital Valley, and Sacramento Valley basins have been previously investigated in both regional studies and more focused local studies. Regional studies include that by Oppenheimer and Sumner (1980), who constructed two-dimensional gravity profiles across alluvial basins throughout Arizona and then interpolated between profiles to produce a three-dimensional basin geometry map. Their study assumed that the average fill density in a particular basin varies as a function of the gravity anomaly; larger anomalies were inferred to correspond to thicker basin fill and higher average densities, ranging from about 2.04 to 2.42 grams per cubic centimeter $\left(\mathrm{g} / \mathrm{cm}^{3}\right)$. Langenheim and others (2010) investigated gravity and magnetic anomalies in the northern Colorado River extensional corridor and Lake Mead region. They produced a map of the Cenozoic basin thickness based on a gravity inversion and density variations within the basement. Their basin-fill-thickness map, as well as magnetic and gravity gradient analysis, provided a means for mapping faults in the area covered by later Cenozoic deposits. Their study, which defined basement (or bedrock) to be pre-Cenozoic, differs from the present study in that Tertiary volcanic and sedimentary rocks were categorized as basin fill. They used the method of Jachens and Moring (1990), modified to include subsurface constraints, and used the isostatic gravity anomalies and data as input into the analysis. Gravity data were reduced to isostatic anomalies by using a crustal density of $2.67 \mathrm{~g} / \mathrm{cm}^{3}$, a sea-level crustal thickness of $25 \mathrm{~km}$ and a mantle-crust density contrast of $0.40 \mathrm{~g} / \mathrm{cm}^{3}$ to remove the long-wavelength gravitational effects of isostatic compensation of the crust due to topographic loading.

Local basin geometry studies were previously completed for each of the three valley basins using large numbers of gravity data collected by the ADWR (Mason and others, 2007; Conway and Ivanich, 2008; Ivanich and Conway, 2009). The three studies each modeled two-dimensional profiles of lithologic units from gravity data that were interpolated to construct a single three-dimensional model, assuming a density of $2.0 \mathrm{~g} / \mathrm{cm}^{3}$ for unsaturated alluvium, $2.25 \mathrm{~g} / \mathrm{cm}^{3}$ for 


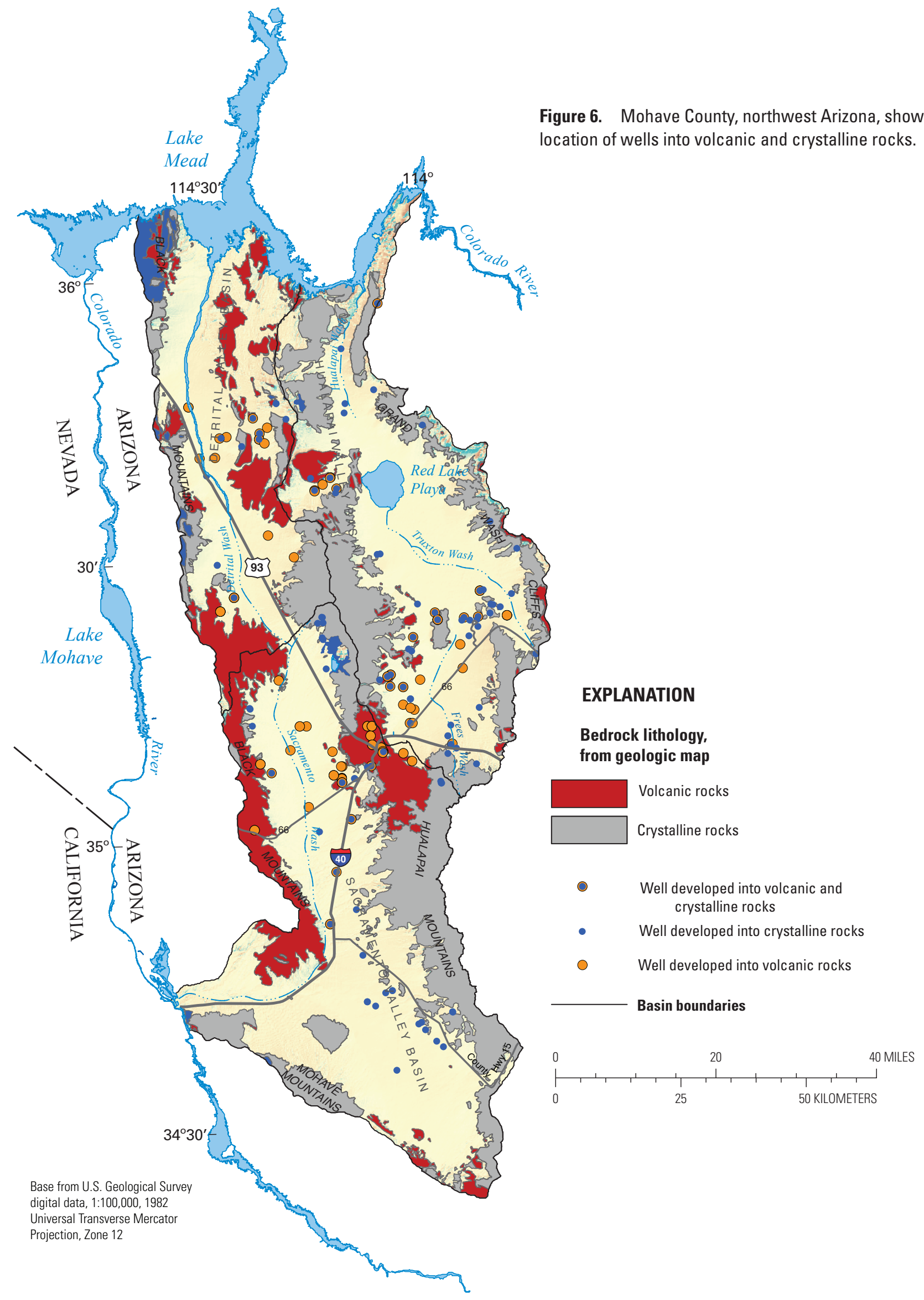




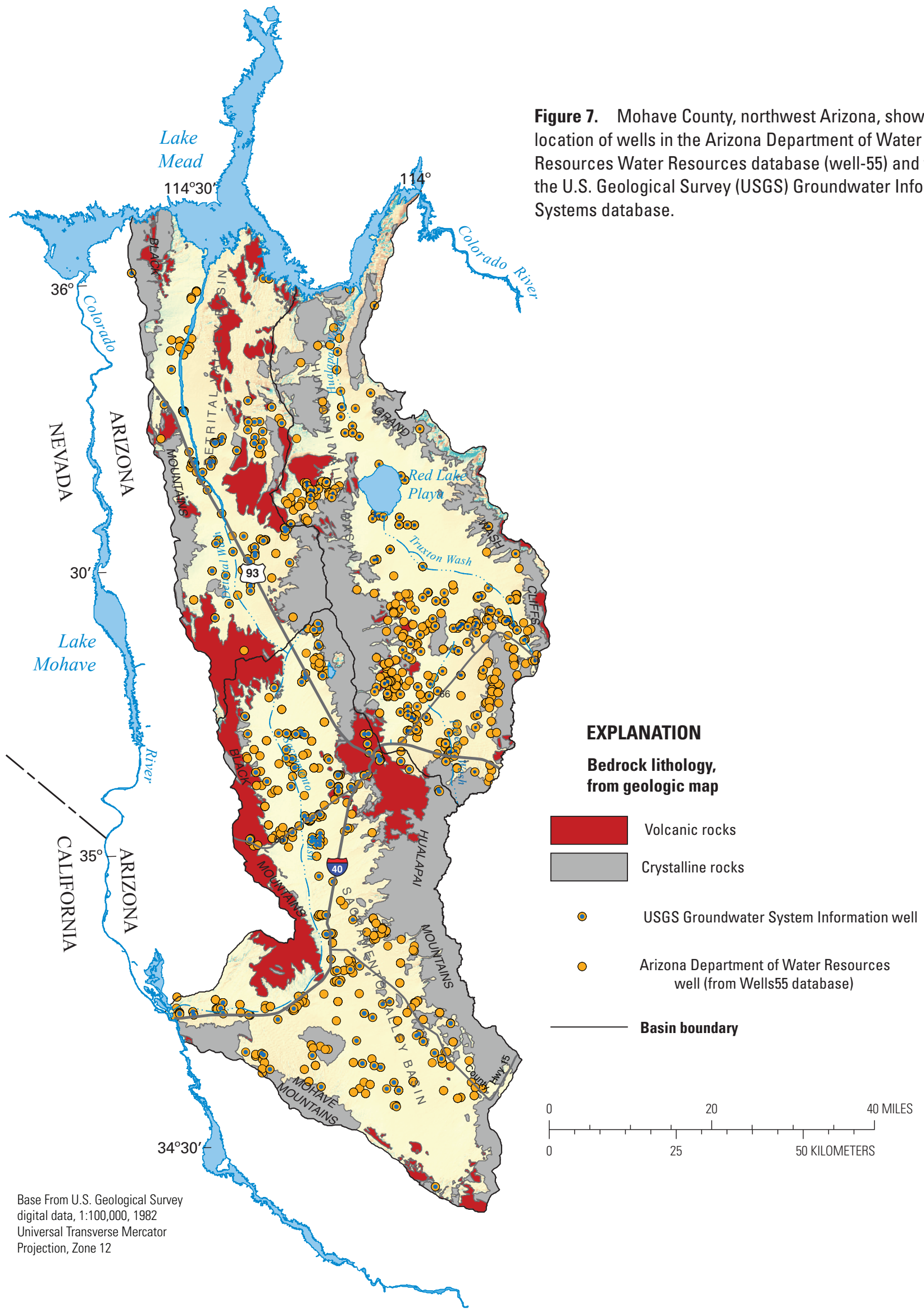


saturated alluvium, and $2.67 \mathrm{~g} / \mathrm{cm}^{3}$ for bedrock (crystalline rocks). Ivanich and Conway (2009) created a basin geometry map for the Hualapai Valley basin based on 456 gravity points. A total of 29 profiles were modeled with either three or four layers - a bedrock layer, an unsaturated alluvial layer, a saturated alluvial layer, and in some profiles a salt layer with a density of $2.1 \mathrm{~g} / \mathrm{cm}^{3}$. Mason and others (2007) created a basin geometry model for the Detrital Valley basin based on 310 new gravity stations for a total of 1,716 gravity points; 35 profiles were modeled throughout the valley basin. Conway and Ivanich (2008) constructed a basin geometry model of the Sacramento Valley basin based on 316 new gravity stations for a total of 1,804 gravity points; 36 profiles were modeled throughout the valley basin. The present study differs from these three ADWR studies by directly modeling a single, continuous, three-dimensional depth-to-bedrock surface rather than interpolating between two-dimensional profiles.

\section{Basin Gravity Anomaly}

The first series of steps towards constructing a basin geometry model involves compiling gravity data, applying several corrections to these gravity data, and then constructing the basin gravity anomaly. Gravity data from 10,681 stations, consisting of published tide- and drift-corrected gravity readings, station positions, and terrain corrections, were used to create a basin gravity anomaly map for this study. The data include the ADWR dataset (Mason and others, 2007; Conway and Ivanich, 2008; Ivanich and Conway, 2009) and historical data obtained from the Pan-American Center for Earth and Environmental Studies dataset (Pan-American Center for Earth and Environmental Studies, 2008). Free-air and Bouguer corrections were calculated by using standard formulas (Hinze and others, 2005). The Bouguer correction, including the Bullard spherical cap correction, was calculated by assuming an Earth radius of $6,371 \mathrm{~km}$, a crustal density of $2.67 \mathrm{~g} / \mathrm{cm}^{3}$, and a Newtonian gravitational constant of $6.673 \times 10^{-11}$ cubic meters per kilogram-square second $\left(\mathrm{m}^{3} \mathrm{~kg}^{-1} \mathrm{~s}^{-2} ; \mathrm{LaFehr}, 1991\right)$. Corrected gravity values were spatially interpolated by using kriging to create the complete Bouguer anomaly (fig. $8 A$ ). Grid cells located $7 \mathrm{~km}$ or more from the closest gravity station were filled in a second step by linear interpolation from the nearest kriged cells. Anomaly grids were upward-continued to a constant elevation of 2,550 m, above the highest topography in the model domain, to facilitate iterative forward modeling.

Although the complete Bouguer anomaly takes into account the elevation of a gravity station, the attractive mass of the underlying material, and the effect of surrounding terrain, an effect remains due to varying crustal thickness, caused by isostatic compensation, in which regions of elevated topography are underlain by thickened crust. This effect can be significant in areas of high topographic relief, such as in the transition from low-lying sedimentary basins to the Colorado Plateau in the study area (fig. 1). The effect of isostatic compensation was modeled and removed from the complete Bouguer anomaly to create the isostatic anomaly by using the Airyroot routine
(Simpson and others, 1983), assuming a sea-level crustal thickness of $30 \mathrm{~km}$, a crustal density $2.67 \mathrm{~g} / \mathrm{cm}^{3}$, and a mantle-crust density contrast of $0.33 \mathrm{~g} / \mathrm{cm}^{3}$. Isostatic anomalies at most of the bedrock gravity stations range from -45 to -25 milliGal ( $\mathrm{mGal}$ ), indicating that crustal densities in the study area are less than the value of $2.67 \mathrm{~g} / \mathrm{cm}^{3}$. One likely reason for this difference is the widespread deposition of ash-flow tuffs and other Tertiary volcanic rocks in the study area (Beard and others, 2011), which typically have an average density lower than that of other bedrock geologic formations (Langenheim and others, 2010). The most negative bedrock gravity anomalies occur in the Black Mountains on the west side of the Detrital Valley and Sacramento Valley basins, and correspond to the extensive occurrence of volcanic rocks (fig. $8 B$ ).

To compensate for the negative-anomaly effect of lowdensity volcanic rocks, a new gravity-anomaly grid was generated from the isostatic anomaly by gridding values only from stations on bedrock (which includes volcanic rocks). This bedrock gravity grid (fig. 8C) was then subtracted from the residual isostatic anomaly to arrive at the basin anomaly grid (fig. $8 D$ ), using an iterative process to account for the effect of low-density sedimentary material on adjacent bedrock stations (Jachens and Moring, 1990).

\section{Construction of the Basin Geometry Model}

The basin isostatic anomaly (fig. $8 D$ ) is caused by a density contrast between higher-density bedrock (crystalline and volcanic rocks) and lower-density basin fill (boulder and cobble conglomerate, gravel and sand, and halite, anyhydrite, gypsum, and evaporite deposits). The magnitude of this anomaly is proportional to the thickness of the basin fill. A basin geometry model of the geologic units and their density was constructed by using the GMSYS-3D software from Geosoft, Inc., to simulate a gravity response due to both the thickness and lateral extent of basin fill (fig. $8 D$ ). An iterative forwardmodeling process was used to construct the basin geometry model by simulating a gravity field that most closely matched the measured gravity field in the study area (fig.1).

The basin geometry model for the study area consists of three lithologic layers. The upper two layers are represented by unsaturated and saturated basin fill, and assigned densities of 2.0 and $2.25 \mathrm{~g} / \mathrm{cm}^{3}$, respectively, on the basis of local and regional borehole density logs (Ivanich and Conway, 2009). These upper two layers are separated by a continuous surface defined by the potentiometric groundwater surface (Anning and others, 2007), which coincides with the saturated/unsaturated basin fill boundary. The bottom represents homogeneous bedrock with a density of $2.67 \mathrm{~g} / \mathrm{cm}^{3}$. If significant compaction of basin fill occurs at depth, the density contrast between basin fill and bedrock would be smaller, and basin thicknesses would be underestimated. A constant-density bedrock layer is appropriate because bedrock heterogeneities have previously been removed as the bedrock anomaly. In areas where bedrock isostatic anomalies differ significantly across a valley basin, such as in the southern part of the Sacramento Valley basin, 

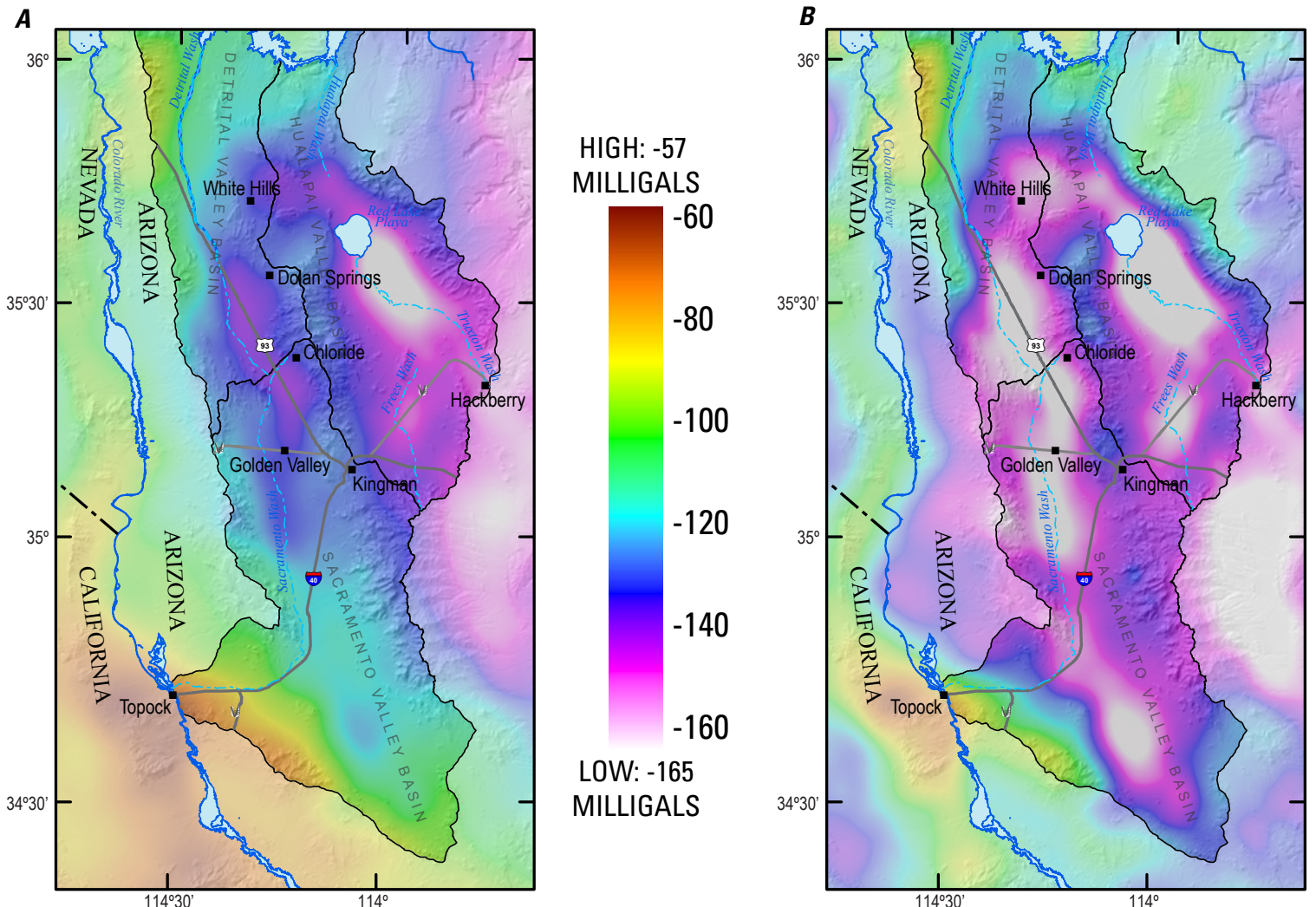

HIGH: 0

MILLIGALS

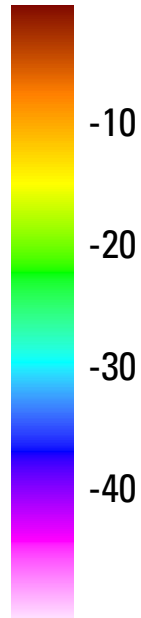

LOW: -50

MILLIGALS

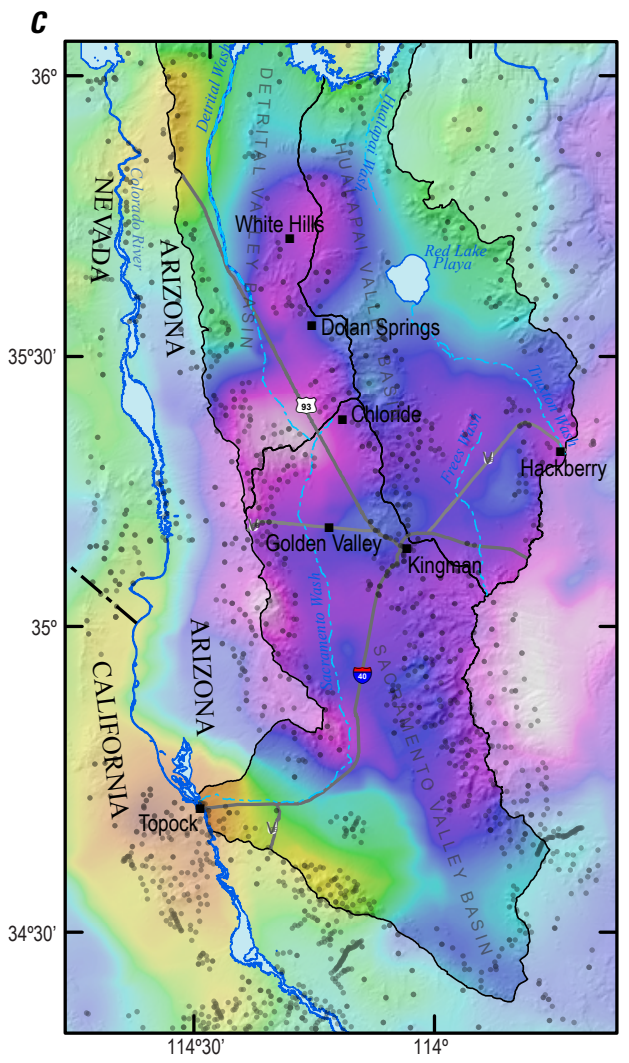

HIGH: 0

MILLIGALS

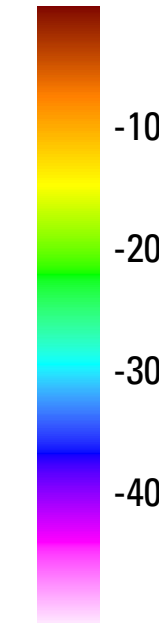

D

LOW: -50

MILLIGALS

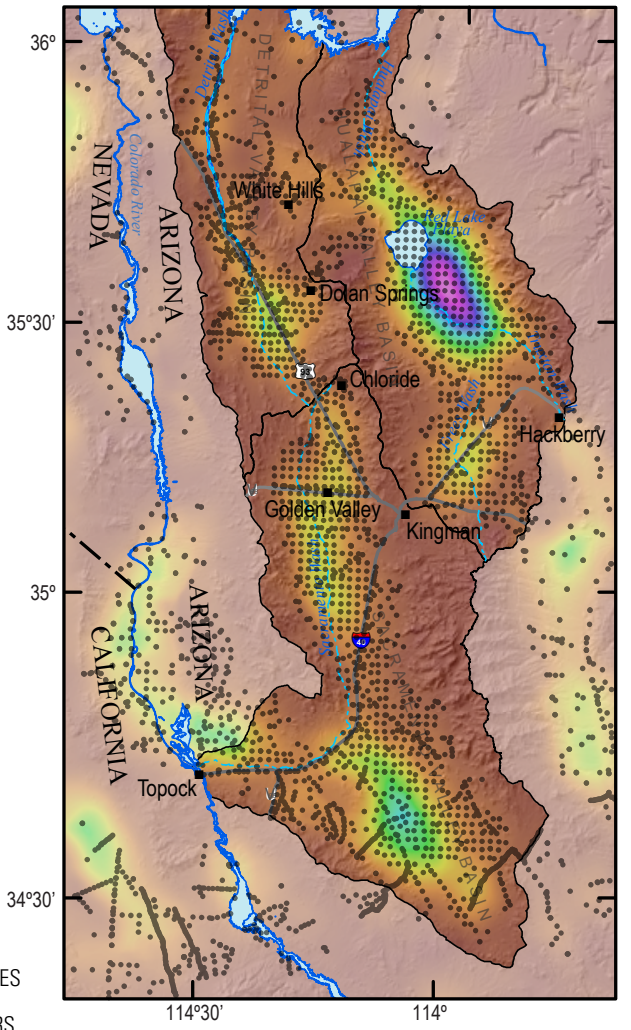

HIGH: 0

MILLIGALS

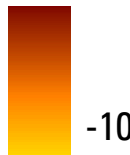

$-20$

$-30$

$-40$

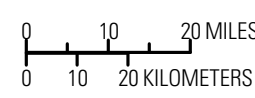

MILLIGALS

Figure 8. Basin gravity anomaly in Mohave County, northwest Arizona. $A$, Complete Bouger anomaly. $B$, Isostatic residual anomaly. $C$, Bedrock residual anomaly. $D$, Basin residual anomaly. Gray circles indicate position of gravity measurements. All grids are upwardcontinued to $2,550 \mathrm{~m}$ elevation. Color scale for figures $B$ through $D$ is identical. 
the model is more uncertain because the configuration of bedrock units with contrasting densities is hidden beneath the basin fill. In other words, uncertainty in the bedrock residual (fig. 8C) in areas interpolated between bedrock stations results in further uncertainty in the basin residual (fig. $8 D$ ). Density logs from boreholes drilled into the Red Lake salt body in the Hualapai subbasin indicate densities of 2.06 and $2.24 \mathrm{~g} / \mathrm{cm}^{3}$ for interbedded salt and shale, respectively (Faulds and others, 1997), not significantly different from the density of basin fill, and so a separate model layer for salt was not needed.

After defining lithologic layers for the basin geometry model, the next step was to determine the thickness of the unsaturated basin fill, after which the thickness of the saturated basin fill could be determined in an iterative process. Lithologic layers must be spatially continuous throughout the study area (fig. 1) to construct the model, even if this assumption requires that they have zero thickness. Thus, where bedrock is exposed at the surface, the upper two layers (saturated and unsaturated basin fill) are assigned a zero thickness. The interface between these layers - a continuous surface that coincides with the land surface where bedrock is exposed, and at the water table where basin fill is exposed - was created as follows. First, a triangulated irregular network (TIN) was created by using the water-table contours of Anning and others (2007). The boundary of this TIN is the contact, at the land surface elevation, between bedrock and basin fill as delineated on the 1:2,500,000-scale U.S. aquifers coverage (National Atlas, 2010). A breakline representing the subsurface contact of the water table with bedrock was constructed by taking the TIN boundary, moving it $58 \mathrm{~m}$ towards the basin center, and lowering it $100 \mathrm{~m}$ in elevation, a value representing an average depth to water at basin margins in the study area. This breakline simulates the effect of mountain blocks with $60^{\circ}$ bounding faults, the approximate angle of many, but not all faults in the study area. The TIN was then converted to a $90 \mathrm{~m}$ pixel-size raster by using a natural-neighbor technique, and filtered by using a 10-pixel averaging filter to remove artifacts near the basin boundary. The final surface representing the saturated/ unsaturated basin fill interface was constructed by combining the newly created raster surface where basin fill is exposed, and a digital elevation model (DEM) where bedrock is exposed. Subtraction of the saturated/unsaturated basin fill interface from the land-surface elevation provides the thickness of the unsaturated basin fill.

The iterative modeling process requires that only one surface in the model is varied when attempting to match the modeled gravity field to the measured gravity anomaly. Adequate independent constraint of the depth to saturated basin fill from well $\log$ data allows the boundary between the upper layer (unsaturated basin fill) and middle layer (saturated basin fill) to be fixed. Therefore, the boundary between the middle layer (saturated basin fill) and the bottom layer (bedrock) is adjusted during the modeling process. A constraint grid was used so that no basins were created in areas of exposed bedrock, providing a smooth transition from values of 0 (fully constrained, areas of bedrock) to 1 (unconstrained, areas of basin fill) over a distance of about $3.5 \mathrm{~km}$ and prevented steep drop offs in basin thickness at the basin margins. As a final result, the modeling process yielded estimates of the basin geometry across the study area (fig. 1), which forms the basin geometry model (fig. 9).

An independent check on the quality of the gravityderived basin geometry model can be obtained from drill logs, although the distribution and depth of wells is a major limiting factor. In areas where well-log data was available, the basin geometry model was able to provide a more correct approximation of the bedrock boundary along the basin margins. With few exceptions, wells penetrated into bedrock are generally shallow and near the basin margins (fig. 10). No deep wells$1,000 \mathrm{~m}$ or more, typical of oil and gas exploration-were available for use in this study to validate the basin geometry model in the deepest basins, and so these depths should be taken as estimates only. The spatial configuration of subbasins, however, should be accurate, particularly where the bedrock anomaly does not vary widely across a valley basin.

\section{Interpreted Resistivity Profiles}

Resistivity values from airborne TEM surveys were interpreted to help identify the boundary between basin fill and bedrock, to help distinguish thick, fine-grained from coarser grained basin fill lithologic units, and to construct lithologic profiles for use in the hydrogeologic framework. Specifically, interpretation of the resistivity data, with ground-truthing from surface geology and well-log lithologic data, helped define the aquifer extent and allowed for differentiation of fine-grained silt, clay, and gypsum/anhydrite and halite, medium- and coarse-grained sand and gravel, and crystalline and volcanic rocks.

Airborne TEM surveys were conducted in the study area by Fugro Airborne Surveys of Calgary, Alberta, Canada using the GEOTEM system, which was selected as the survey method because of its greater depth of investigation (300-400 $\mathrm{m}$ bls) in comparison with the helicopter-based systems that were available in 2006. The GEOTEM system consists of a transmitter on an airplane towing a three-coil receiver. The system transmits a periodic $30 \mathrm{Hertz}(\mathrm{Hz})$ electromagnetic field as a waveform with a half-sine current pulse of 4.045 milliseconds (ms). The transmitter is offset from the receiver approximately $132 \mathrm{~m}$ horizontally and $39 \mathrm{~m}$ vertically, which theoretically provides better depth resolution than a colocated transmitter and receiver. Originally, the data were obtained as 5 ontime channels and 15 offtime channels. However, examination of the dataset indicated that the transient response with better definition of early and midtime data would result in improved resistivity models. The original data were therefore reprocessed to provide 20 offtime channels distributed to increase early and midtime samples at the expense of fewer late samples, which were generally of insufficient quality. The pulse width was $4.05 \mathrm{~ms}$, and the midtimes of the channels 


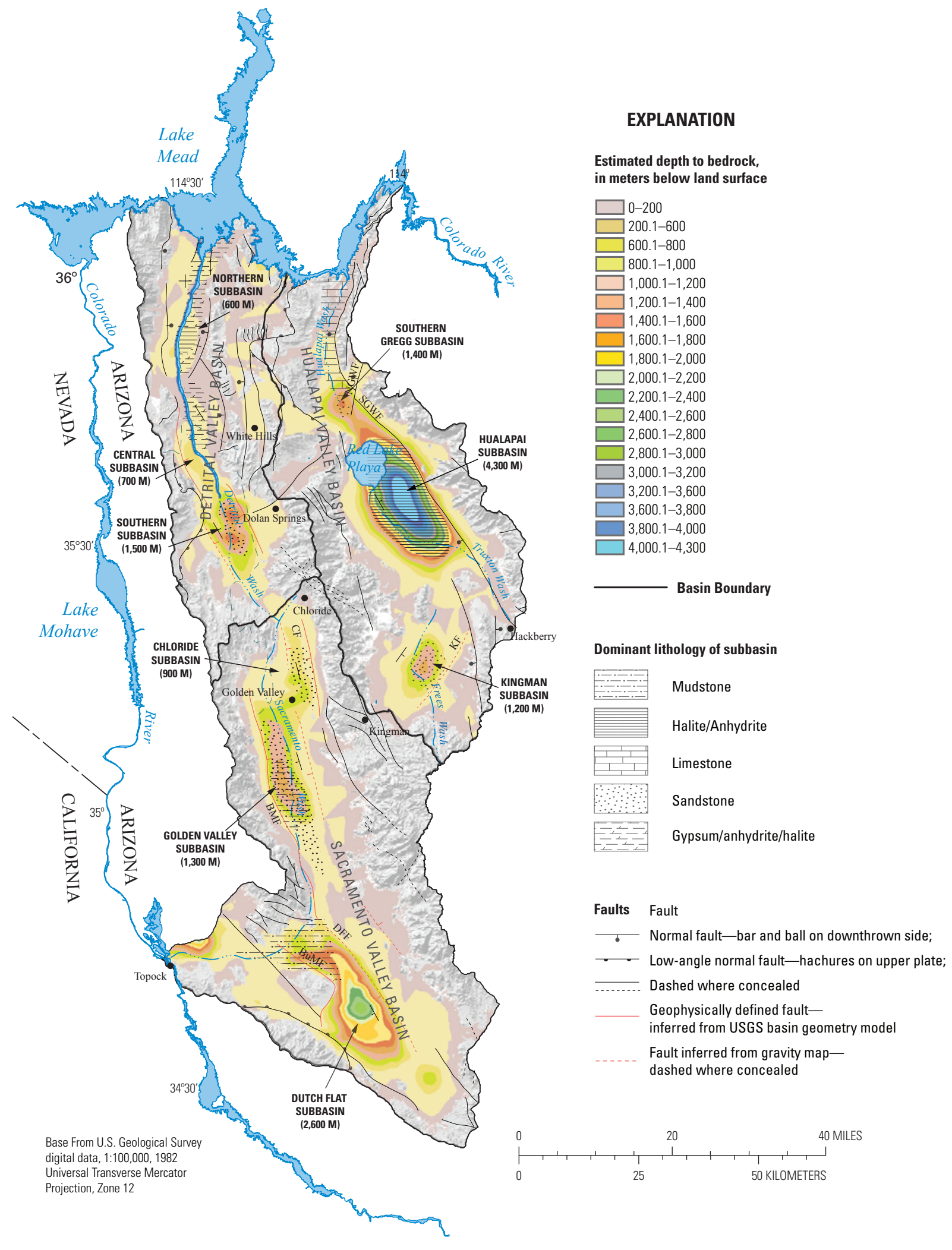

Figure 9. Basin geometry model showing subbasins and estimated depths given in meters, $m$ in the Hualapai Valley, Detrital Valley, and Sacramento Valley Basins, Mohave County, northwestern Arizona. Mapped faults are shown in black; black hachured lines are low-angle detachment faults. Faults inferred from basin geometry model gravity model and transient electromagnetic data shown in red. Dashed red lines denote higher degree of uncertainty (BMF, Black Mountain Fault; BuMF, Buck Mountain Fault; CF, Chloride Fault; DDF, Dutch Flat Fault; KF, Kingman Fault; NGWF, northern section of the Grand Wash Fault; SGWF, southern section of the Grand Wash Fault). 


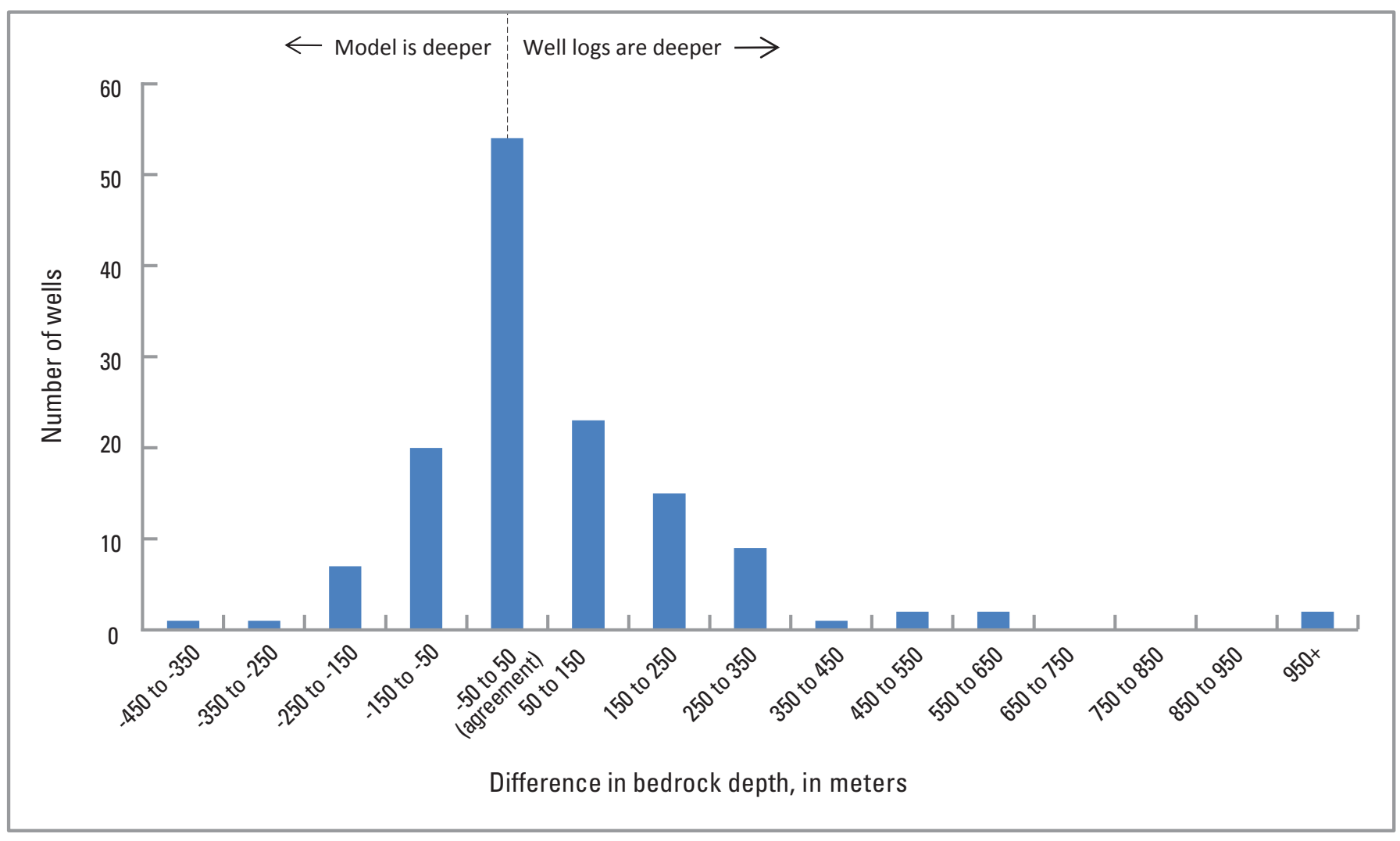

Figure 10. Histogram of difference in bedrock depth between the basin geometry model and well logs. Each point that forms the histogram population is calculated by subtracting well-log depth from model depth. Negative values indicate that modeled depths are below bedrock surface in well logs. Wells that did not reach bedrock were omitted.

ranged from 4.28 to $14.29 \mathrm{~ms}$ from the beginning of the pulse (Dickinson and others, 2009).

The airborne TEM surveys included 1,293 km of profiles in total length that were flown over the 3 valley basins. The Detrital Valley basin, which is elongated southeast to northwest, had 21 flightlines equaling $528 \mathrm{~km}$ (fig. 11), 12 of which were flown generally parallel to the basin and 5 generally perpendicular to the basin. Four GEOTEM flightlines flown in the Detrital Valley basin extended into the northern part of the Hualapai Valley basin, which had a total of 18 flightlines equaling $545 \mathrm{~km}$, with 13 north-south flightlines, four eastwest flightlines, and two southeast-northwest flightlines. GEOTEM lines in the Hualapai Valley basin were flown only north of the Kingman subbasin because of cultural interference from the electrical signals from homes, septic systems, powerlines, roads, and other manmade objects close to Kingman. The Sacramento Valley basin had a total of 19 flightlines equaling 220 $\mathrm{km}$, with 16 eastwest flightlines down the center of the valley basins, and three north-south flightlines flown perpendicular to the east-west flightlines (fig. 11).

One-dimensional models of electrical resistivity versus depth derived from the airborne GEOTEM data were constructed by Petros Eikon, Inc., of Toronto, Ontario, Canada, to map subsurface electrical resistivity (Dickinson and others, 2009). All 20 channels were used to construct the resistivity models. The one-dimensional resistivity models were calibrated in several places on the basis of drill-log control, using the EMIGMA software from Petros Eikon, Inc. The onedimensional GEOTEM models, which consist of six horizontal layers of uniform electrical resistivity, were imported into the Environmental Science Research Institute's ArcGIS software as two-dimensional cross sections, which used surface elevations derived from the DEM in combination with well-log lithology, groundwater levels, and surface geology to infer subsurface lithology (table 1). The two-dimensional cross sections of resistivity values are referred to as "uninterpreted resistivity profiles," and the two-dimensional cross sections of inferred lithology to as "interpreted resistivity profiles." The inferred lithology within each interpreted resistivity profile was digitized in ArcMap and brought into ArcScene to better visualize in three-dimensions the basin geometry model, well logs, and surface geology. In some places, interpretation of the resistivity data was obscured by two factors: (1) areas where modeled GEOTEM profiles showed interference from powerlines, housing communities, roads, and other structures; and (or) (2) areas where the deeper resistivity signal was obscured through attenuation from the overlying low-resistivity signal.

Interpretation of the resistivity profiles involved delineation of lithologic units based on resistivities, with guidance from well log lithology and geologic information. The basin 


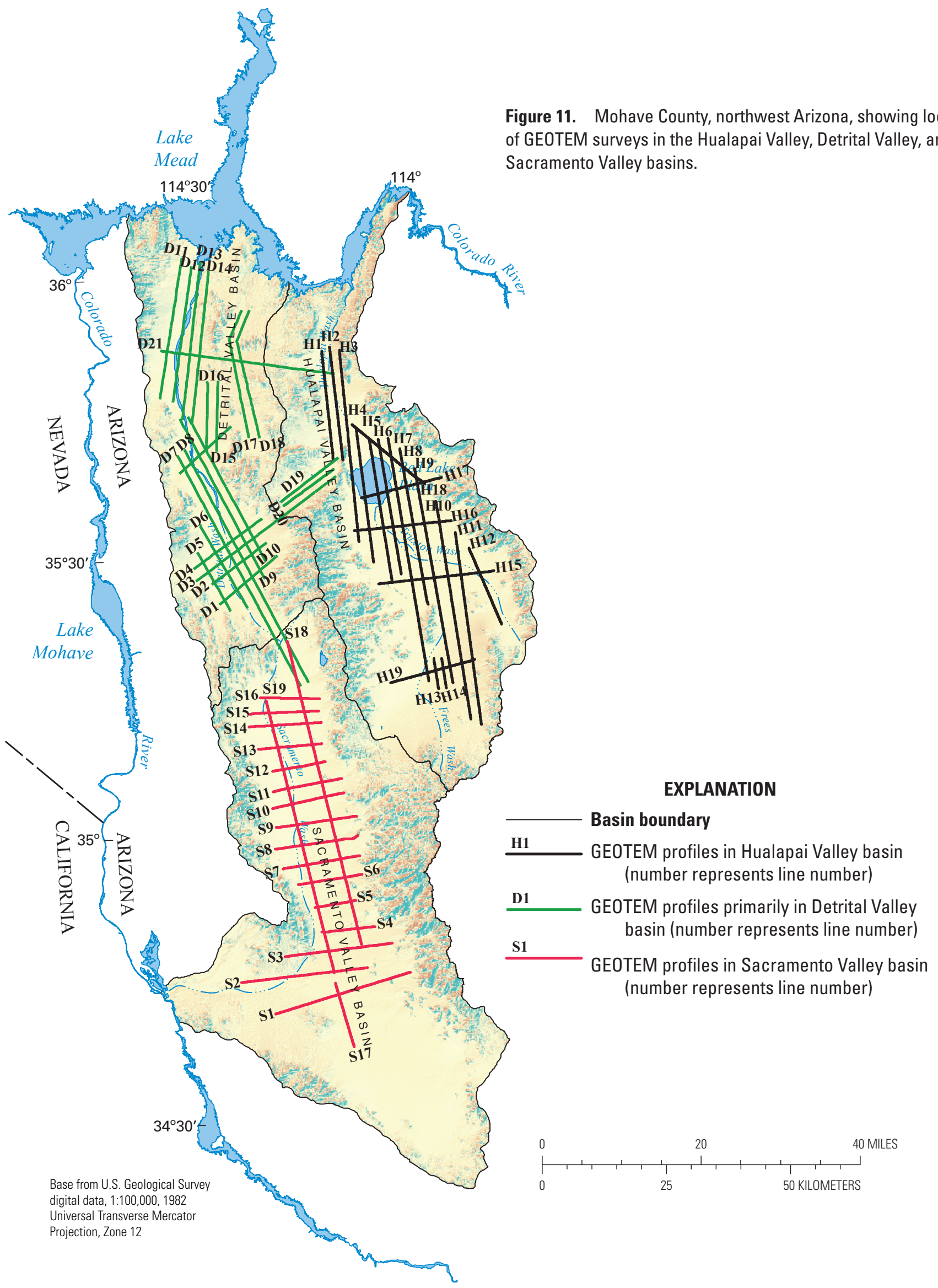


fill in the resistivity profiles represented is relatively shallow in consideration of the total depth of the basins, and primarily correlates with the Miocene basin fill shown in figure $4 B$ and the late Pliocene and Quaternary surficial deposits shown in figure $4 C$. The electrical properties of the subsurface basin fill and rocks in the three alluvial basins varied depending on sediment size, saturated versus unsaturated basin fill, and bedrock type. The resistivity profiles were interpreted by spatially delineating the extent of lithologic units and assigning them into one of the following classes: unsaturated coarse-grained basin fill, unsaturated medium-grained basin fill, unsaturated fine-grained basin fill, saturated coarse-grained basin fill, saturated medium-grained basin fill, saturated fine-grained basin fill, limestone, crystalline rocks, and volcanic rocks. A description of these units, including grain size, resistivity, and associated depositional environments, is included in tables 1 and 3. The interpretation of the resistivity data was consistent with generalized ranges for basin fill and various rock types (Pool and Coes, 1999).

Although the resistivity profiles were mainly used to infer basin fill lithology, some of the profiles flown over bedrock also delineate bedrock outcrops. Sections of resistivity profiles with higher resistivities, between 100 and 200 ohm-meters $(\Omega \cdot \mathrm{m})$, occur in the shallow subsurface near the boundary between crystalline bedrock and alluvial fan deposits along the mountain fronts. In some places interpretation of the resistivity profiles suggests that the depth to bedrock may differ from the basin geometry model (fig. 12). In other places, the well-log lithologic data and basin geometry model were used instead of the resistivity profiles to better define the transition from crystalline bedrock to alluvial-fan deposits (fig. 13; table 1). In still other areas, subhorizontal layers and (or) successive vertical changes in resistivity (generally from 30 to $100 \Omega \cdot \mathrm{m}$ ) along the resistivity profiles were mapped as volcanic material where surface geology and structure indicated the possible presence of volcanic rocks in the subsurface (fig. 14). Well-log lithologic data were commonly available to verify an interpretation of volcanic rocks; however, in areas with few or no wells, the layered and (or) successive vertical changes in resistivity were interpreted to indicate volcanic rocks, as mostly occurred in the Golden Valley subbasin of the Sacramento Valley basin.

In areas where few or no well-log lithologic data were available, interpretation of the resistivity profiles was inferred from general knowledge of the depositional setting of shallow subsurface geologic units, including:

- Lacustrine/playa: typified by limestone, evaporite, halite, and mudstone;

- Shorelines/eolian: consisting of typically fine- to coarsegrained clastic sediment — dry deposits of mudstone, siltstone, sandstone, pebbly sandstone, and sandy conglomerate; and

- Alluvial fans and alluvial plains: consisting of typically coarse-grained deposits including sandstone and conglomerate (table 1).

Table 3. Relation between lithology and approximate ranges in resistivity values.

\begin{tabular}{|c|c|c|c|c|}
\hline \multirow{2}{*}{$\begin{array}{l}\text { Lithologic unit, } \\
\text { interpreted from } \\
\text { Resisitivity }\end{array}$} & \multirow[t]{2}{*}{ Lithology from well logs } & \multicolumn{2}{|c|}{ Lithologic description } & \multirow{2}{*}{$\begin{array}{c}\text { Approximate resistivity } \\
\text { values }\end{array}$} \\
\hline & & Rock type & Grain size & \\
\hline $\begin{array}{l}\text { Unsaturated coarse } \\
\text { grained basin fill }\end{array}$ & Coarse grained sediments & Sand, gravel, boulders & medium, coarse & $>50$ \\
\hline $\begin{array}{l}\text { Unsaturated medium } \\
\text { grained baisin fill }\end{array}$ & $\begin{array}{l}\text { Medium grained } \\
\text { sediments }\end{array}$ & Silt, sand, some gravel & medium, coarse & $30-50$ \\
\hline $\begin{array}{l}\text { Unsaturated fine grained } \\
\text { basin fill }\end{array}$ & $\begin{array}{l}\text { Fine grained sediments/ } \\
\text { evaporite }\end{array}$ & $\begin{array}{l}\text { Clay, silt, sand, halite, } \\
\text { gypsum, anhydrite }\end{array}$ & fine & $0.5-20$ \\
\hline $\begin{array}{l}\text { Saturated coarse grained } \\
\text { basin fill }\end{array}$ & Coarse grained sediments & Sand, gravel, boulders & medium, coarse & $>50$ \\
\hline $\begin{array}{l}\text { Saturated medium grained } \\
\text { basin fill }\end{array}$ & $\begin{array}{l}\text { Medium grained } \\
\text { sediments }\end{array}$ & Silt, Sand, some gravel & medium, coarse & $30-50$ \\
\hline $\begin{array}{l}\text { Saturated fine grained } \\
\text { basin fill }\end{array}$ & $\begin{array}{l}\text { Fine grained sediments/ } \\
\text { evaporite }\end{array}$ & $\begin{array}{l}\text { Clay, silt, sand, halite, } \\
\text { gypsum, anhydrite }\end{array}$ & fine & $0.5-20$ \\
\hline $\begin{array}{l}\text { Undifferentiated } \\
\text { sediments }\end{array}$ & $\begin{array}{l}\text { Grain size } \\
\text { undifferentiated }\end{array}$ & Not applicable & Not applicable & $.5-100$ \\
\hline Indurated sediments & $\begin{array}{l}\text { Coarse grained and } \\
\text { indurated }\end{array}$ & Sand, gravel, boulders & Not applicable & $>100$ \\
\hline Crystalline bedrock & Crystalline bedrock & Crystalline bedrock & Not applicable & $>100$ \\
\hline Volcanic bedrock & Volcanic bedrock & Volcanic bedrock & Not applicable & $20-100$ \\
\hline
\end{tabular}


A

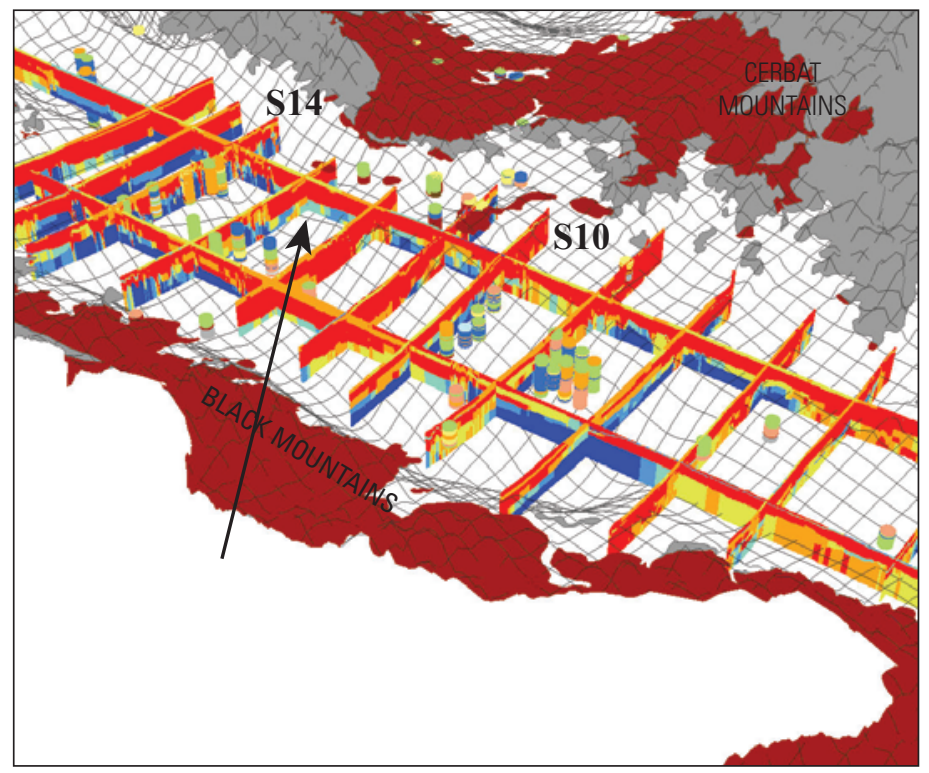

B

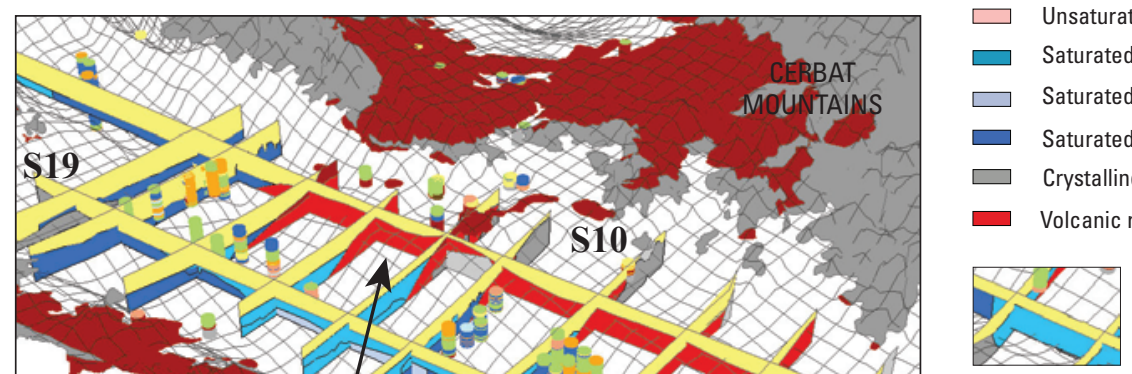
with interpreted lithology

\section{EXPLANATION}

ELECTROMAGNETIC S (fig. 12A)

INTERPRETED FROM RESISTIVITY (fig. 12B)

\section{LITHOLOGY, FROM WELL LOGS}

$\square \quad$ Coarse-grained basin fill

$\square$ Medium-grained basin fill

$\square$ Evaporite

$\square$ Fine-grained basin fill

$\square \quad$ Indurated sediments

$\square$ Undifferentiated sediments

$\square \quad$ Crystalline rocks

Volcanic rocks
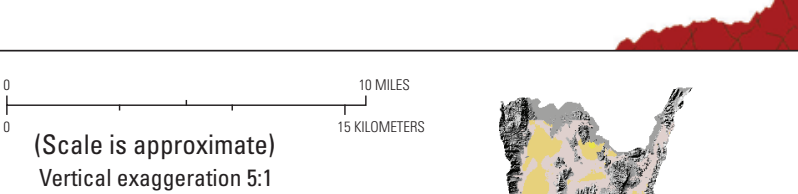

Figure 12. Mohave County, northwest Arizona, showing perspective view to the northeast in the Golden Valley subbasin, Sacramento Valley basin, with example of where the basin geometry model did not match GEOTEM profiles and welllog lithologic interpretation of boundary between volcanic bedrock and basin fill (arrows). Profiles are numbered in the same order as they are in figure 11 .

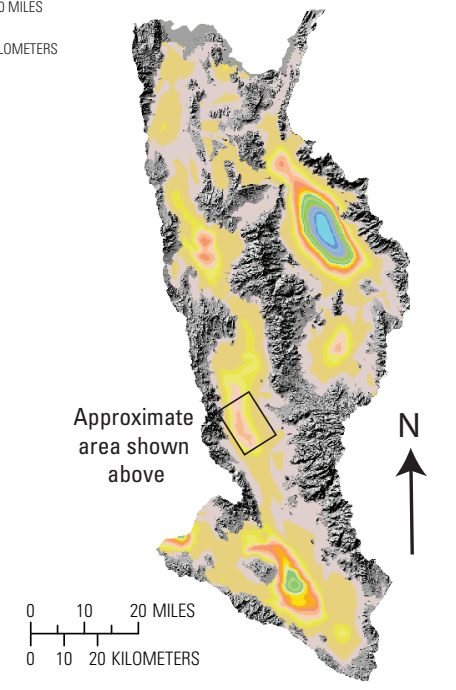




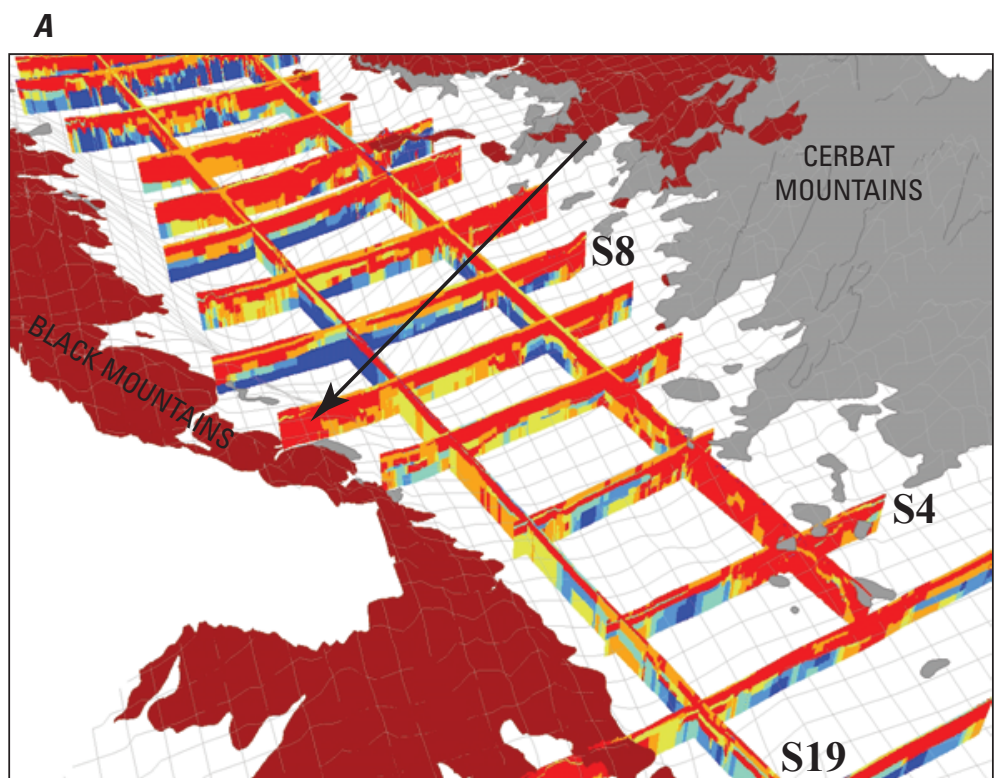

$\boldsymbol{B}$
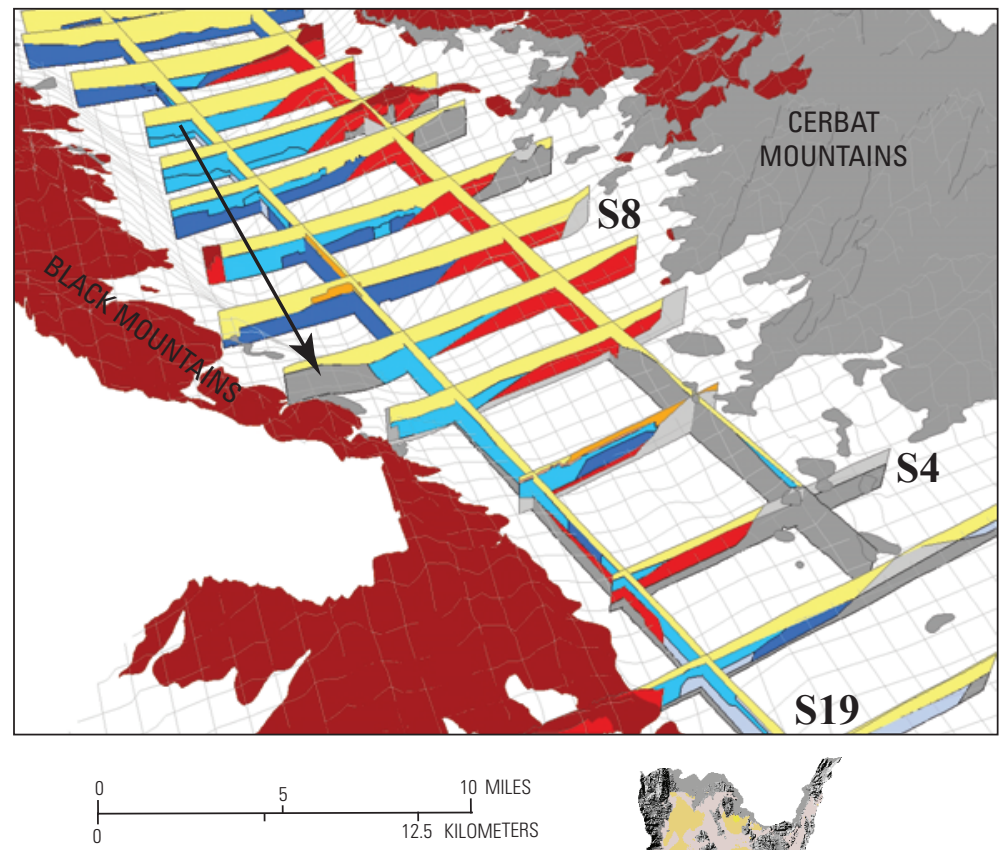

(Scale approximate)

Vertical exaggeration 5:1

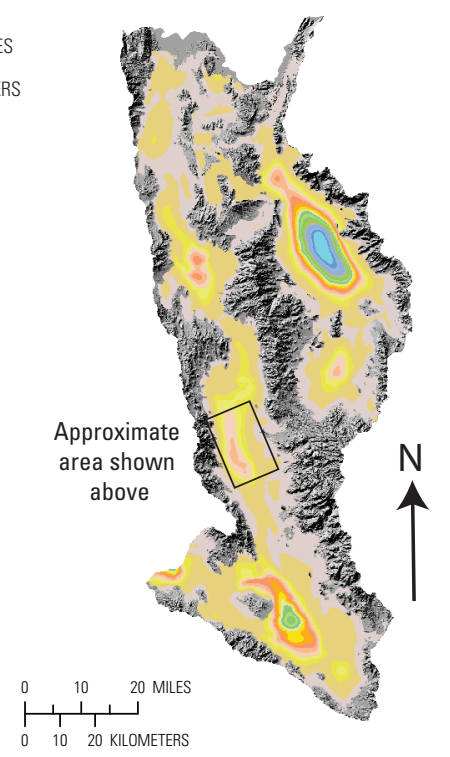

EXPLANATION

TRANSIENT ELECTROMAGNETIC

RESISTIVITY VALUES, IN

OHM-METER (fig. 13A)

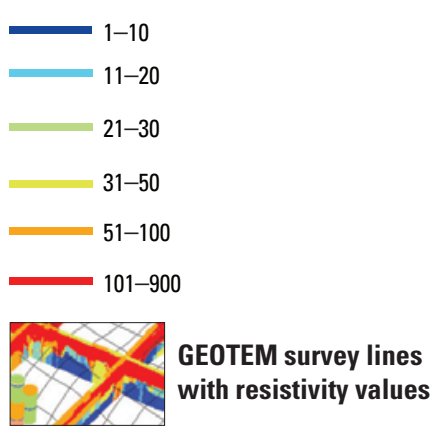

\section{LITHOLOGIC UNITS, INTERPRETED} FROM RESISTIVTY (fig. 13B)

\footnotetext{
$\square \quad$ Unsaturated coarse-grained basin fill

$\square$ Unsaturated medium-grained basin fill

$\square$ Unsaturated fine-grained basin fill

$\square$ Saturated coarse-grained basin fill

$\square$ Saturated medium-grained basin fill

$\square$ Saturated fine-grained basin fill

Limestone

$\square \quad$ Crystalline rock

$\square$ Volcanic rock
}

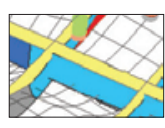

GEOTEM survey lines with interpreted lithology

\section{BEDROCK LITHOLOGY, FROM} GEOLOGIC MAP (figs 13A, 13B)

\footnotetext{
Volcanic rocks

$\square \quad$ Crystalline rocks
}

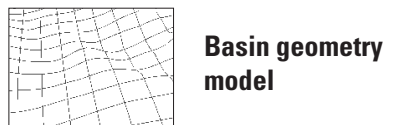

Figure 13. Mohave County, northwest Arizona, showing perspective view to the northeast in the Golden Valley subbasin of the Sacramento Valley basin, with interpretation of high transient electromagnetic resistivity values (>100 $\Omega \bullet \mathrm{m})$, where crystalline bedrock overlain by unsaturated alluvial fans (arrows). Profiles are numbered in the same order as in figure 11. 


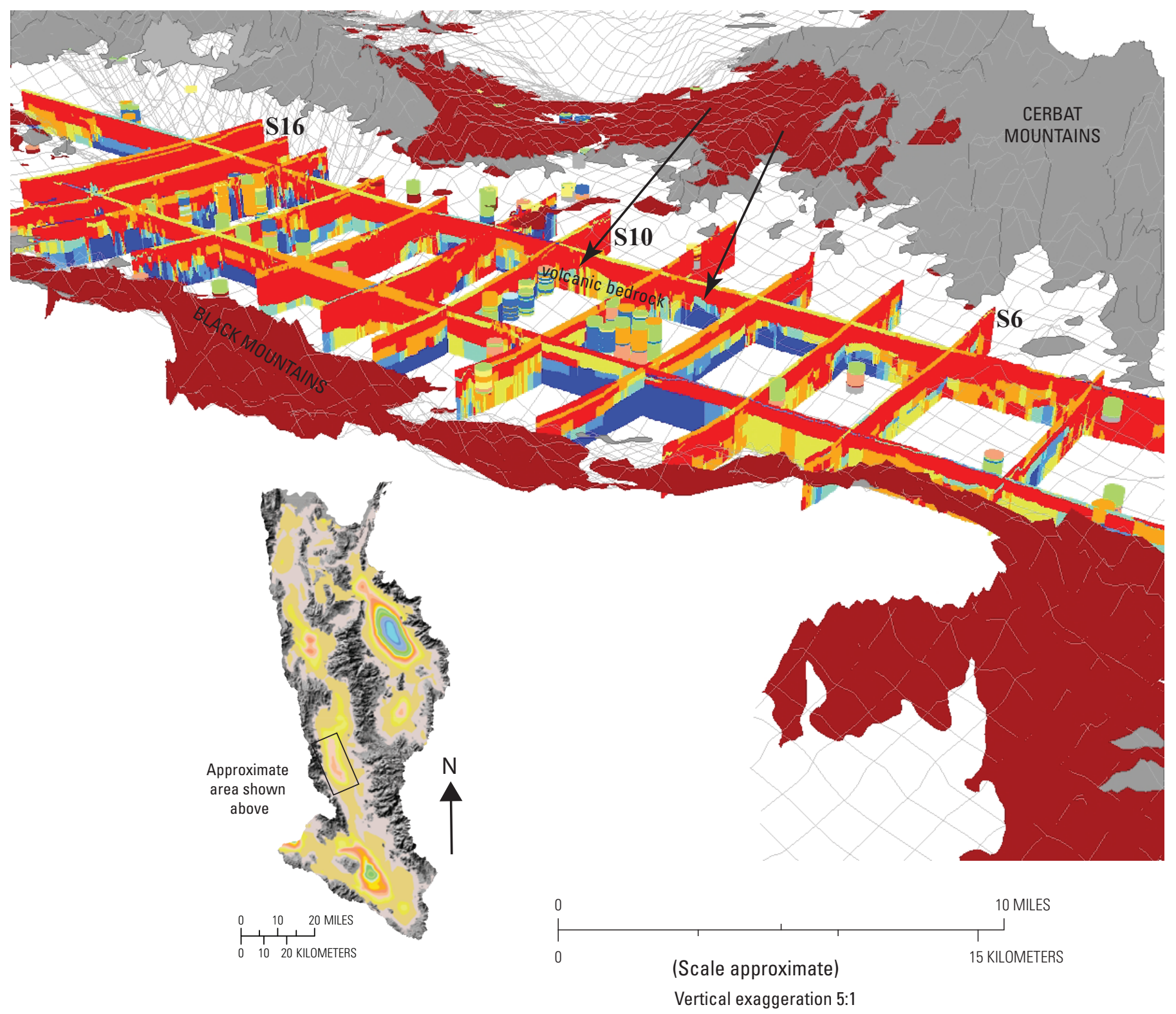

\section{EXPLANATION}

TRANSIENT ELECTROMAGNETIC RESISTIVITY VALUES, IN OHM-METERS

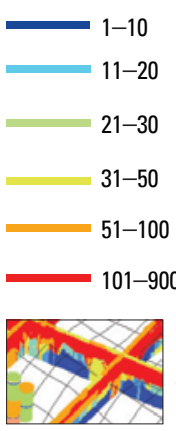

GEOTEM survey lines with resistivity values

\section{LITHOLOGY, FROM WELL LOGS}

$\square \quad$ Coarse-grained basin fill

$\square$ Medium-grained basin fill

$\square$ Evaporite

Fine-grained sediments

$\square \quad$ Indurated sediments

$\square$ Undifferentiated sediments

$\square$ Crystalline rocks

Volcanic rocks

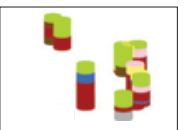

Wells
BEDROCK LITHOLOGY, FROM GEOLOGIC MAP

Volcanic rocks
Crystalline rocks

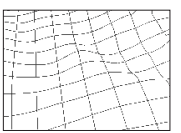

Basin geometry model

Figure 14. Mohave County, northwest Arizona, showing perspective view to northeast in the Golden Valley subbasin, Sacramento Valley basin, with example of the uninterpreted resistivity profile with successive changes in resistivity, well log lithology, and surface geology, interpreted as volcanic bedrock in the subsurface (arrows). Profiles are numbered in the same order as in figure 11. 
Each of the generalized depositional settings for the subbasins defined in the basin geometry model (fig. 9) is briefly defined here. Basin fill in the Kingman subbasin most likely formed in an alluvial-fan depositional environment; basin fill in the Hualapai subbasin is generally characterized by playa/ lacustrine depositional environments; basin fill in the southern Gregg subbasin is generally characterized by lacustrine and (or) shoreline depositional environments in the north and alluvial fan depositional environments in the south; basin fill in the northern Detrital subbasin likely formed in lacustrine/ playa depositional environments; basin fill in the central Detrital subbasin appears to transition from lacustrine/playa to alluvial-fan depositional environments; basin fill in the southern Detrital subbasin is generally characterized by an alluvial fan depositional environment; basin fill in the Chloride subbasin is generally characterized by an alluvial-fan depositional environment; basin fill in the Golden Valley subbasin is generally characterized by alluvial-fan and surficial fluvial depositional environments; and basin fill in the Dutch Flat subbasin is mostly of unknown origin.

\section{Hydrogeologic Framework}

Analysis of the geologic information, well-log lithologic data, basin geometry model, and interpreted resistivity profiles indicates significant differences in the hydrogeologic frameworks of the Hualapai Valley, Detrital Valley, and Sacramento Valley basins. One similarity, however, is that each valley basin comprises three major subbasins. This section describes the hydrogeologic frameworks for the three valley basins and their subbasins.

\section{Hualapai Valley Basin}

The three subbasins identified by basin of the Hualapai Valley basin in the geometry model vary in shape and depth (fig. 9). The Kingman subbasin is generally oval with a southwest-to-northeast axis; an inferred fault (Kingman Fault, fig. 3) based on the basin geometry model parallels the southeastern edge of the subbasin (fig. 9). The Hualapai subbasin is a north-south elongate east-tilted half-graben controlled by the southern section of the Grand Wash Fault that includes a thick deposit of gypsum, anhydrite, and halite. The small southern Gregg subbasin lies east of the southern section of the Grand Wash fault in the northern part of the Hualapai Valley basin.

\section{Kingman Subbasin}

The basin geometry model suggests that the depth of the Kingman subbasin is about $1,200 \mathrm{~m}$ bls (fig. 9). An abrupt cutoff to the pediment and a modeled dropoff in the basin geometry model forms the southern edge of the Kingman subbasin. Wells drilled in the subbasin are generally located around the periphery, are shallow, and penetrate volcanic and (or) crystalline rocks (fig. 10). No deep wells have been drilled close to the center of the basin (fig. 15). Most of the groundwater appears to move northward from the subbasin along the east side of Long Mountain. Water levels from well logs indicate that there may be small amounts of groundwater in basin fill along the west side of Long Mountain.

Resistivity profiles were flown over the north and east edge of the Hualapai Valley basin. Most of the Kingman subbasin was omitted because of the potential effects from cultural interference. Resistivity profiles with values greater than $100 \Omega \cdot \mathrm{m}$ indicate the presence of a bedrock high on the west and east sides of Long Mountain between the Kingman and Hualapai subbasins; depths to bedrock in those areas shallow to about 100 to $200 \mathrm{~m}$ bls (fig. 15). Unsaturated coarsegrained basin fill with resistivity values greater than $100 \Omega \cdot \mathrm{m}$ are described in well logs as overlying the bedrock. North of the bedrock high on either side of Long Mountain is saturated basin fill in medium- to coarse-grained deposits with resistivities ranging from 30 to $100 \Omega \cdot \mathrm{m}$. South of the bedrock high, unsaturated basin fill with resistivities greater than $100 \Omega \cdot \mathrm{m}$ overlies saturated fine-grained basin fill with resistivities ranging from 2 to $10 \Omega \cdot \mathrm{m}$ (fig. 15 ).

\section{Hualapai Subbasin}

The basin geometry model suggests that the depth of the Hualapai subbasin (fig. 9) is 4,300 m bls, deeper than in the ADWR model (3,500 m bls; Ivanich and Conway, 2009). The results of this study are consistent with the estimates by Faulds and others (1997) that are based on seismic-reflection data, and by Langenheim and others (2010) that are based on a gravity analysis that incorporated the seismic constraints. This study uses a depth-density relation identical to that of the ADWR study but includes an iterative basin-bedrock separation process, which likely caused the discrepancy between the USGS and ADWR depths for the subbasin. Groundwater movement defined by the water-table surface in the Hualapai subbasin indicates a shallow hydraulic gradient in the basin fill from south to north toward the southern Gregg subbasin (Anning and others, 2007).

Shallow basin fill sediments in the Hualapai subbasin are interpreted as playa/shoreline deposits, interfingering laterally with alluvial fans and washes. Interpretation of the resistivity profiles for this area identifies unsaturated alluvial fan deposits ranging in resistivity from 50 to $100 \Omega \cdot \mathrm{m}$, playa deposits ranging in resistivity from 5 to $20 \Omega \cdot \mathrm{m}$, and fluvial-channel deposits ranging in resistivity from 30 to $50 \Omega \cdot \mathrm{m}$ (fig. 16). Truxton and Frees Washes form very low-gradient braided plain surfaces that flow northward; Kingman Wash is mostly floored with silt and fine sand, whereas Truxton Wash contributes coarser sediment (Beard and others, 2011). Localized shallow silt and clay deposits yield resistivity values from 5 to $20 \Omega \cdot \mathrm{m}$. Intermediate storms create high flows in both Truxton and Kingman Washes, which deposit fine sediments ranging in resistivity from 0.5 to $20 \Omega \bullet \mathrm{m}$ into Red Lake playa. 


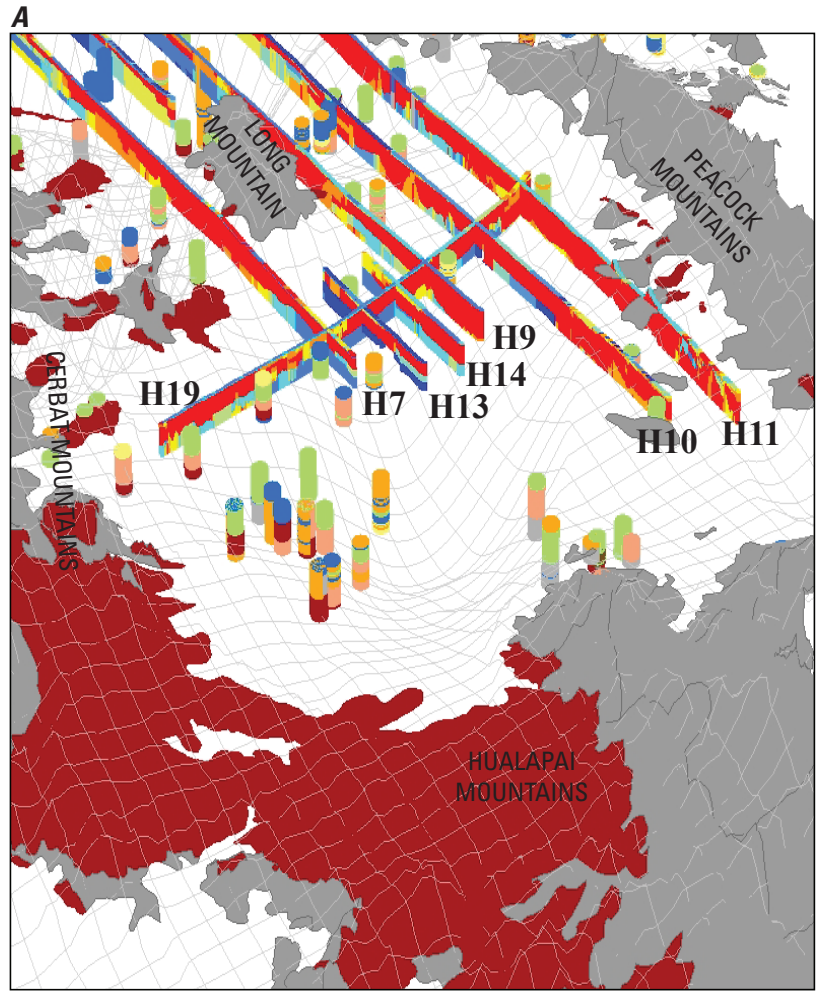

B
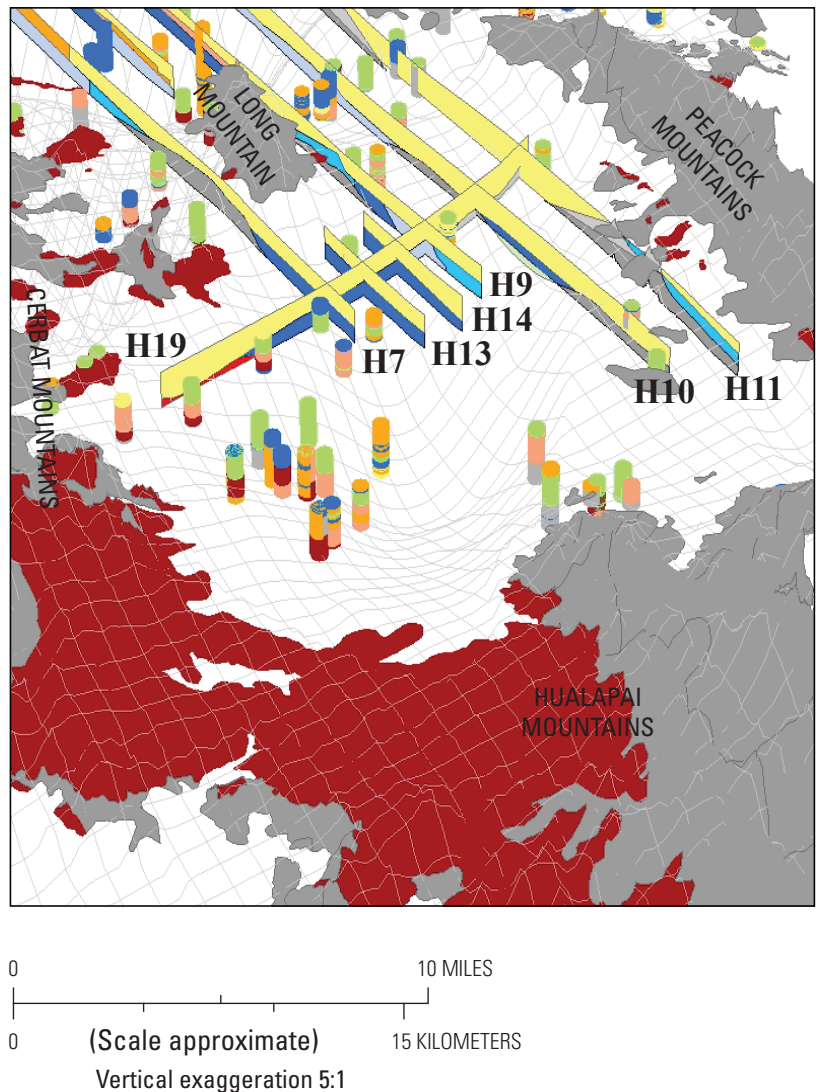

Vertical exaggeration 5:1

\section{EXPLANATION}

TRANSIENT ELECTROMAGNETIC RESISTIVITY VALUES, IN

OHM-METERS (fig. 15A)

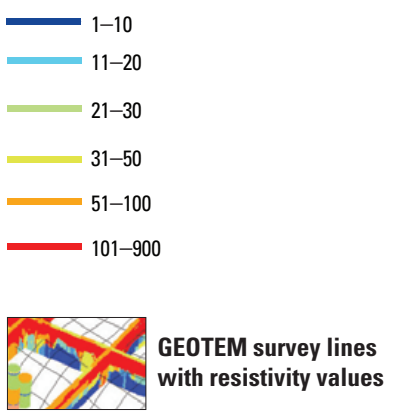

\section{LITHOLOGY, FROM WELL LOGS}
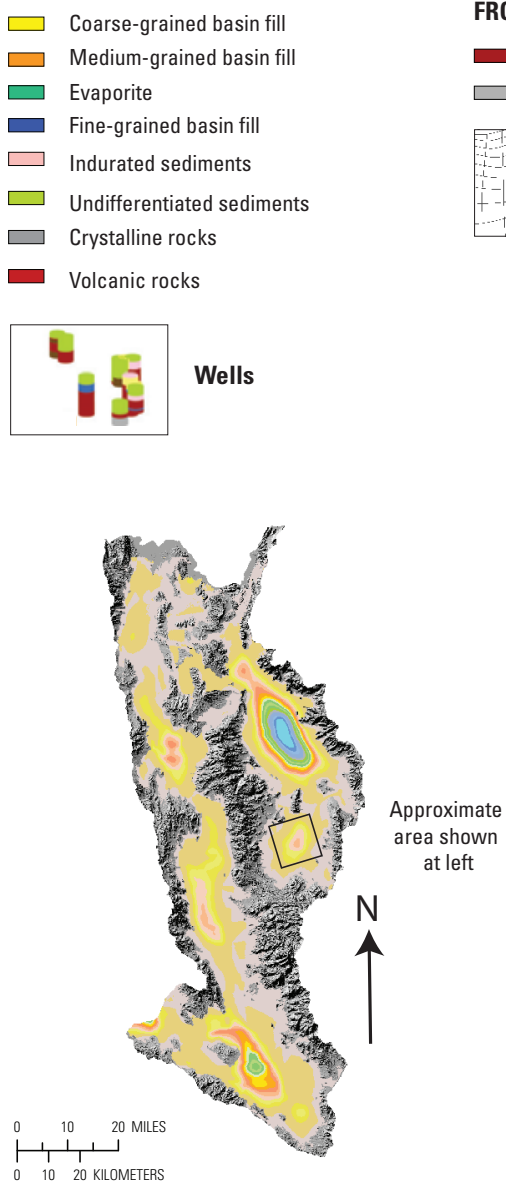

LITHOLOGIC UNITS, FROM INTERPRETED RESISTIVITY (fig. 15B)

$\square$ Unsaturated coarse-grained basin fill

$\square \quad$ Unsaturated medium-grained basin fill

$\square$ Unsaturated fine-grained basin fill

$\square$ Saturated coarse-grained basin fill

$\square$ Saturated medium-grained basin fill

$\square$ Saturated fine-grained basin fill

$\square$ Crystalline rocks

$\square$ Volcanic rocks

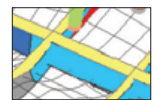

GEOTEM survey lines with interpreted lithology

\section{BEDROCK LITHOLOGY,} FROM GEOLOGIC MAP

Volcanic rocks

$\square \quad$ Crystalline rocks

Basin geometry model
Figure 15. Mohave County, northwest Arizona, showing perspective view to the northeast of uninterpreted $(A)$ and interpreted $(B)$ resistivity from GEOTEM profiles in northern part of the Kingman subbasin of the Hualapai Valley basin. Profiles are numbered in the same order as in figure 11. 
$\boldsymbol{A}$

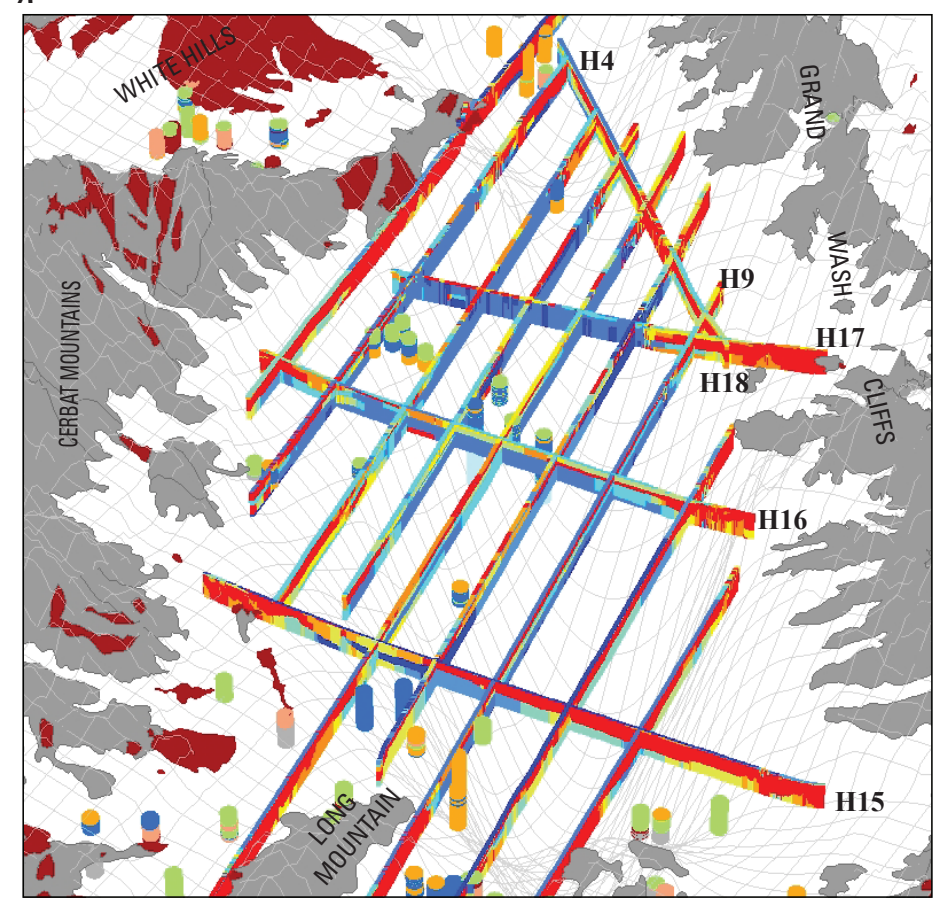

$\boldsymbol{B}$

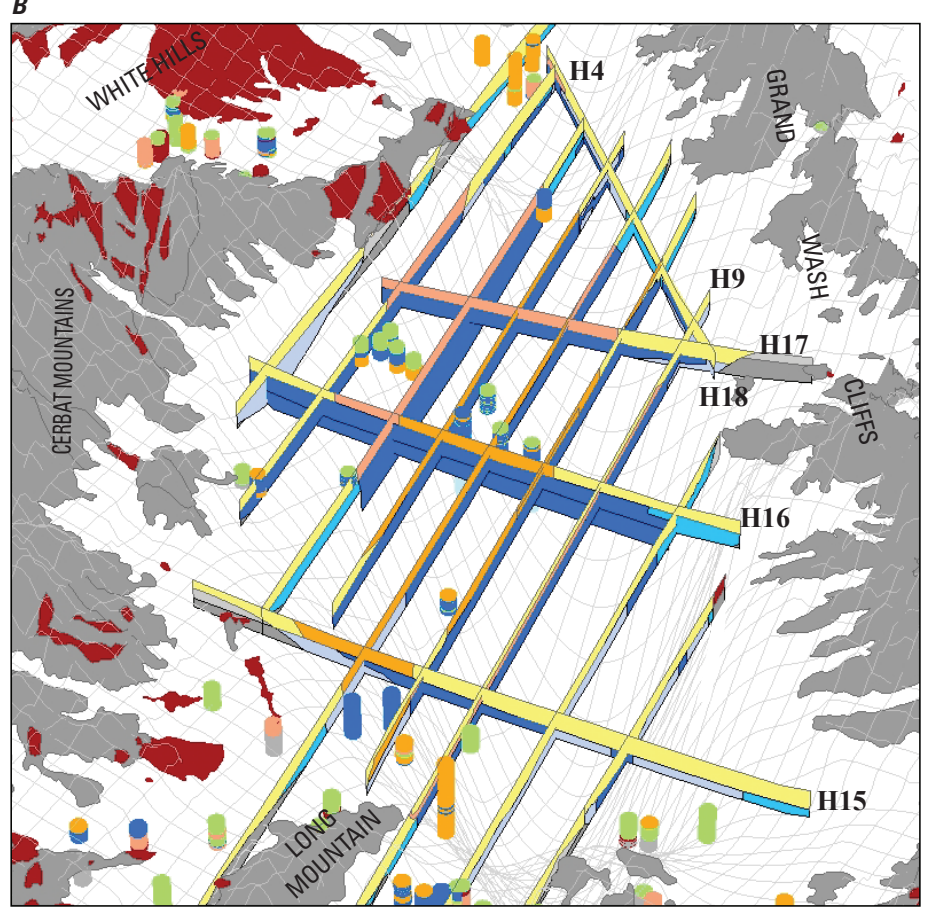

EXPLANATION

\begin{tabular}{lll}
$\begin{array}{l}\text { TRANSIENT ELECTROMAGNETIC } \\
\text { RESISTIVITY VALUES IN }\end{array}$ & LITHOLOGIC UNITS, FROM INTERPRETED \\
OHM-METERS (fig. 16A) & RESISTIVITY (fig. 16B) \\
\hline $1-10$ & $\square$ & Unsaturated coarse-grained basin fill \\
$11-20$ & $\square$ & Unsaturated medium-grained basin fill \\
$21-30$ & $\square$ & Unsaturated fine-grained basin fill \\
$31-50$ & $\square$ & Saturated coarse-grained basin fill \\
$51-100$ & $\square$ & Saturated medium-grained basin fill \\
$101-900$ & $\square$ & Saturated fine-grained basin fill \\
\hline-100 & Crystalline rock \\
\hline
\end{tabular}

GEOTEM survey lines with resistivity values

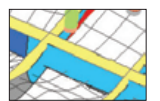

GEOTEM survey lines with interpreted lithology
BEDROCK LITHOLOGY, FROM GEOLOGIC MAP (figs. 16A and 16B)

$$
\begin{array}{ll}
\square \quad \text { Coarse-grained sediments } \\
\text { Medium-grained sediments } \\
\square \quad \text { Evaporite } \\
\square \quad \text { Fine-grained sediments } \\
\text { Indurated sediments } \\
\square \quad \text { Undifferentiated sediments } \\
\begin{array}{l}
\text { Crystalline rocks } \\
\text { Volcanic rocks }
\end{array}
\end{array}
$$

$\square$ Volcanic rocks

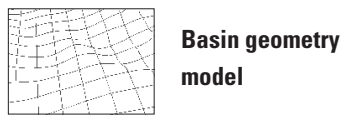

\section{Wells}

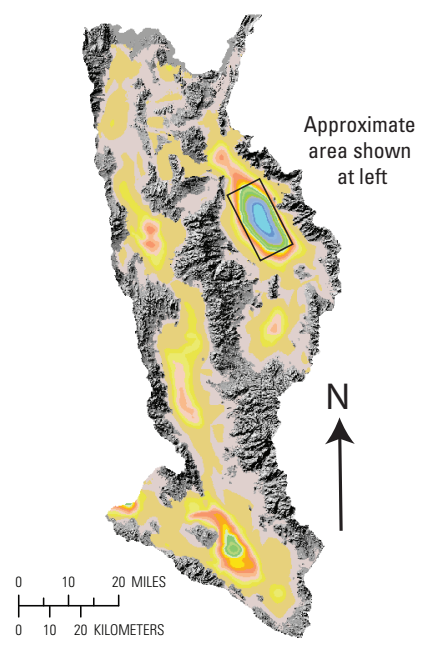

Figure 16. Mohave County, northwest Arizona, showing perspective view to northwest of uninterpreted $(A)$, and interpreted $(B)$ resistivity from GEOTEM profiles in Hualapai subbasin, Hualapai Valley basin. Interpretation of resistivity may differ along profiles that are perpendicular to one another, suggesting that the basin fill may be interlayered and (or) a factor of resistivity modeling where some surface interference may have occurred or lithology attenuated signal. Profiles are numbered in the same order as in figure 11. 
A thick salt body that underlies the alluvial-fan and playa deposits at about 400 to $600 \mathrm{~m}$ bls extends to a depth of at least 4,300 m bls. The lateral extent of the salt body was defined by previous studies (Davis and Conradi, 1981; Faulds and others, 1997; Ivanich and Conway, 2009). Generally this salt body appears to fill most of the Hualapai subbasin laterally and vertically to the west edge of the subbasin along the Cerbat Mountains (Faulds and others, 1997). Well-log lithologic data and very low electrical resistivities of about 0.5 to $5 \Omega \cdot \mathrm{m}$ suggest fine sediment and salty water in the shallow subsurface below Red Lake playa, likely above the salt body.

\section{Southern Gregg Subbasin}

The basin geometry model suggests that the southern Gregg subbasin is small, narrow, and 1,400 $\mathrm{m}$ deep at its deepest point (fig. 9), Langenheim and others (2010) also showed a small subbasin on the basis of their analysis. Groundwater movement in the basin-fill aquifer is restricted by the narrow bedrock borders causing an increase in the hydraulic gradient from south to north (Anning and others, 2007). The basin fill is dissected at the north end of the subbasin by Hualapai Wash, exposing Hualapai Limestone and fine-grained lacustrine deposits that interfinger laterally with shoreline and alluvialfan deposits.

Farther south in the subbasin, resistivity profiles and well-log lithologic data suggest that saturated limestone with resistivities of 10 to $30 \Omega \cdot \mathrm{m}$ may overlie medium-grained basin fill with resistivities 20 to $40 \Omega \cdot \mathrm{m}$ at the north end of the subbasin (fig. 17). Southward, well-log lithologic data, with water levels and resistivities of more than $100 \Omega \bullet \mathrm{m}$, indicate that unsaturated coarse-grained basin fill may overlie mostly saturated coarse-grained deposits with minor fine-grained basin fill.

\section{Detrital Valley Basin}

The basin geometry model shows that the Detrital Valley basin is underlain by three subbasins. The northern Detrital subbasin is partly dissected by Detrital Wash, and so some late Miocene basin fill is exposed near Lake Mead (fig. 5B). In contrast, the two other subbasins are buried beneath surficial deposits.

\section{Northern Detrital Subbasin}

The basin geometry model estimates the depth of the northern Detrital subbasin to be $600 \mathrm{~m}$ bls (fig. 9), comparable to the estimate by Mason and others (2007) of about $700 \mathrm{~m}$ bls. Water levels toward the center of the subbasin may be lower than $400 \mathrm{~m}$ bls. The evaporite unit is generally dry, although some artesian water levels may be present; therefore, groundwater withdrawals from wells drilled in this area would likely have low yield and poor water quality (Mason and others, 2007; Towne and Stephenson, 2003).
Well-log lithologic data indicate low resistivities ranging from 0.5 to $5 \Omega \cdot \mathrm{m}$, in interbedded clays and gypsum/ anhydrite/halite deposits (fig. 18). Mason and others (2007) referred to the gypsum/anhydrite/halite deposits within the subbasin and extending southward as the "clay unit." Less than $1 \mathrm{~m}$ of undifferentiated unconsolidated alluvial material, described in several well logs, overlies some of the interbedded clays and gypsum/anhydrite/halite deposits (fig. 5B).

\section{Central Detrital Subbasin}

The basin geometry model suggests that the depth of the central Detrital subbasin may be only $700 \mathrm{~m}$ bls (fig. 9); Mason and others (2007) estimated its depth to be 700 to 850 $\mathrm{m}$ bls. The central subbasin is not as well defined by the basin geometry model as are the two subbasins to the north and south, possibly because of lateral density changes related to a large alluvial fan from the east that may be influencing the modeled basin shape and depth (Beard and others, 2011).

Well-log lithologic data suggest that low resistivities from 0.5 to $10 \Omega \cdot \mathrm{m}$ represent about 200 to $300 \mathrm{~m}$ of gypsum/anhydrite/halite in the northern part of the subbasin. Several wells on the northeast side penetrated gypsum and clay, with minor consolidated conglomerate, and granite at about $400 \mathrm{~m}$ bls. The upper 100 to $200 \mathrm{~m}$ bls generally consists of a coarser sand-and-gravel alluvial-fan deposit with resistivities of 60 to $200 \Omega \cdot \mathrm{m}$ (fig. 19), which is locally thicker and probably part of a large alluvial fan that extends westward from the White Hills (Beard and others, 2011). The top of the gypsum/anhydrite/halite sequence was likely eroded by stream channels and filled with 200 to $400 \mathrm{~m}$ of alluvial basin fill near the south end of the central Detrital subbasin, north of Dolan Springs. Resistivities in the 200- to 400-m-thick sequence of alluvial basin fill range from 100 to $200 \Omega \cdot \mathrm{m}$ (fig. 19).

Groundwater moves northward on a shallow hydraulic gradient several hundred meters below the land surface. The water table coincides with a sharp drop in resistivities from $100-200 \Omega \cdot \mathrm{m}$ to $5-40 \Omega \cdot \mathrm{m}$ (fig. 20) that can be explained from a combination of (1) well-log lithologic data that indicates that the upper $350 \mathrm{~m}$ bls is medium- to coarse-grained basin fill underlain by the gypsum/anhydrite/halite sequence, which underlies the alluvial fan deposit at about 350 to $400 \mathrm{~m}$ bls; and (2) water-quality data (Towne and Stephenson, 2003), which show elevated concentrations of sodium, chloride, and sulfate, likely from dissolution of the underlying gypsum/anhydrite/ halite sequence.

\section{Southern Detrital Subbasin}

The basin geometry model from this study and those of others (Mason and others, 2007; Langenheim and others, 2010) indicate that the southern Detrital subbasin is elongate north-south. The basin geometry model estimates the depth of the subbasin to be $1,500 \mathrm{~m}$ bls (fig. 9), consistent with Mason and others' (2007) estimate of 1,000-1,500 m bls. The model 

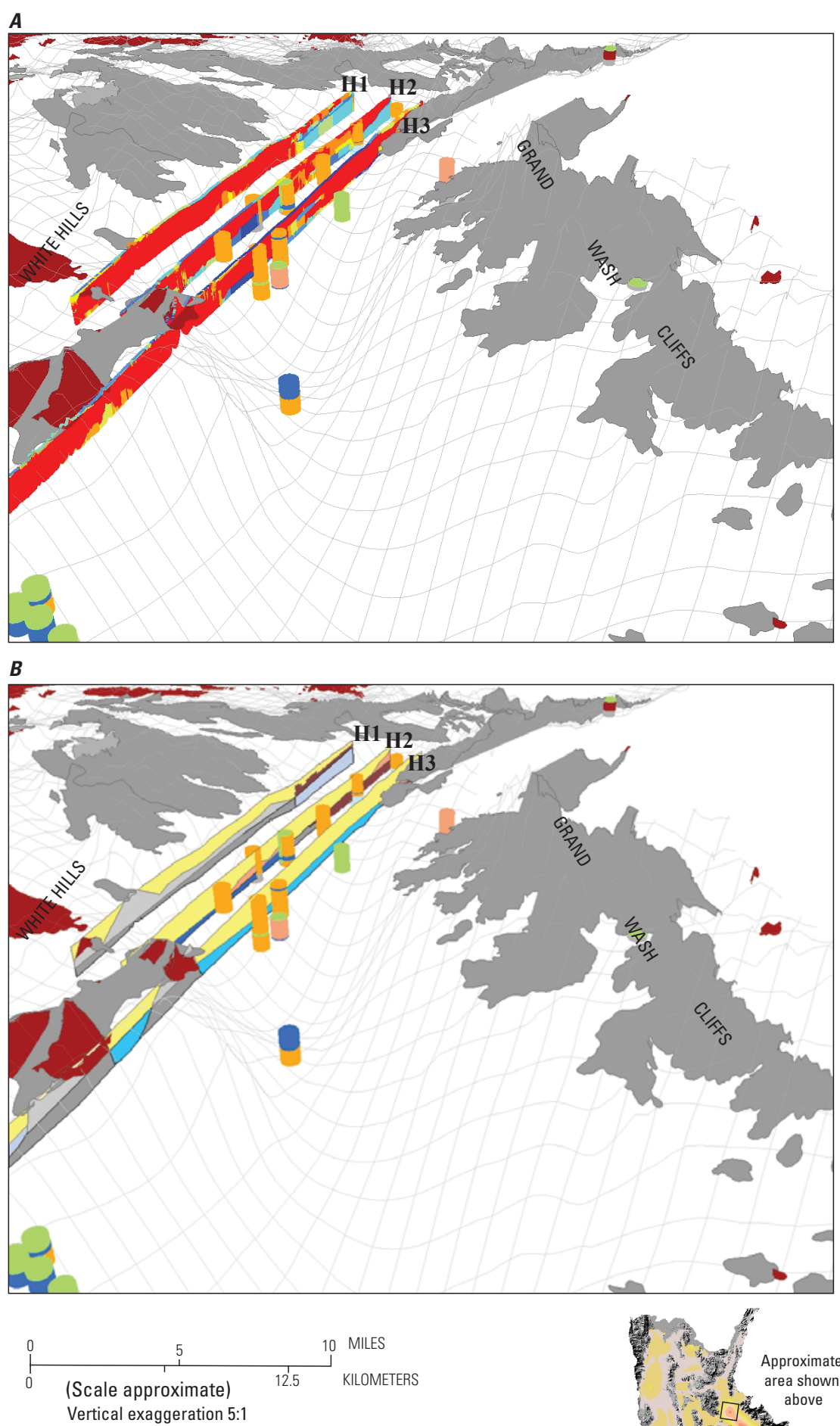

Vertical exaggeration $5: 1$

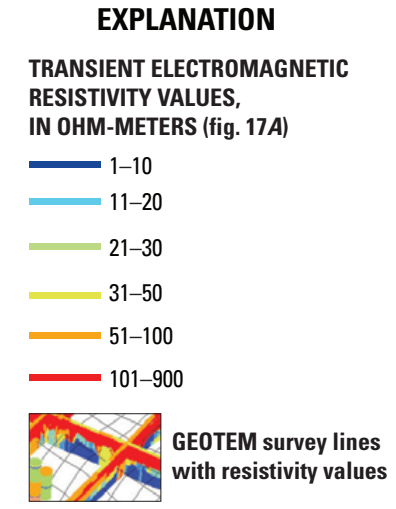

LITHOLOGIC UNITS, INTERPRETED FROM RESISTIVITY (fig. 17B)

$\square$ Unsaturated coarse-grained basin fill

$\square$ Unsaturated medium-grained basin fill

$\square \quad$ Unsaturated fine-grained basin fill

$\square$ Saturated coarse-grained basin fill

$\square$ Saturated medium-grained basin fill

$\square$ Saturated fine-grained basin fill

Limestone

$\square \quad$ Crystalline rock

Volcanic rock

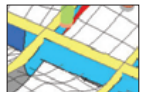

\section{GEOTEM survey lines with interpreted} lithology

\section{LITHOLOGY, FROM WELL LOGS (figs. 17A and $B$ ) \\ $\square$ Coarse-grained sediments \\ $\square$ Medium-grained sediments \\ $\square$ Evaporite \\ $\square$ Fine-grained sediments \\ $\square \quad$ Indurated sediments \\ $\square \quad$ Undifferentiated sediments \\ $\square$ Crystalline rocks \\ Volcanic rocks

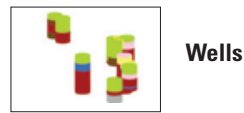 \\ BEDROCK LITHOLOGY, \\ FROM GEOLOGIC MAP \\ Volcanic rocks \\ $\square \quad$ Crystalline rocks

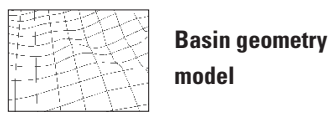

Figure 17. Mohave County, northwest Arizona, showing perspective view to the northwest of uninterpreted $(A)$ and interpreted $(B)$ resistivity from GEOTEM profiles in southern Gregg subbasin, Hualapai Valley basin. Profiles are numbered in the same order as in figure 11. 


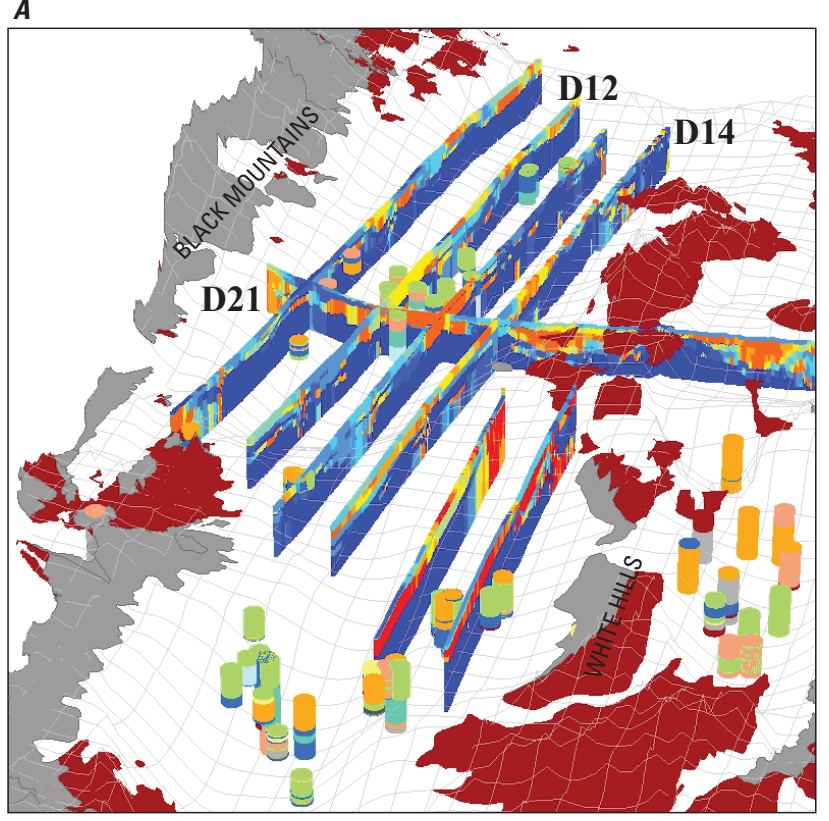

B
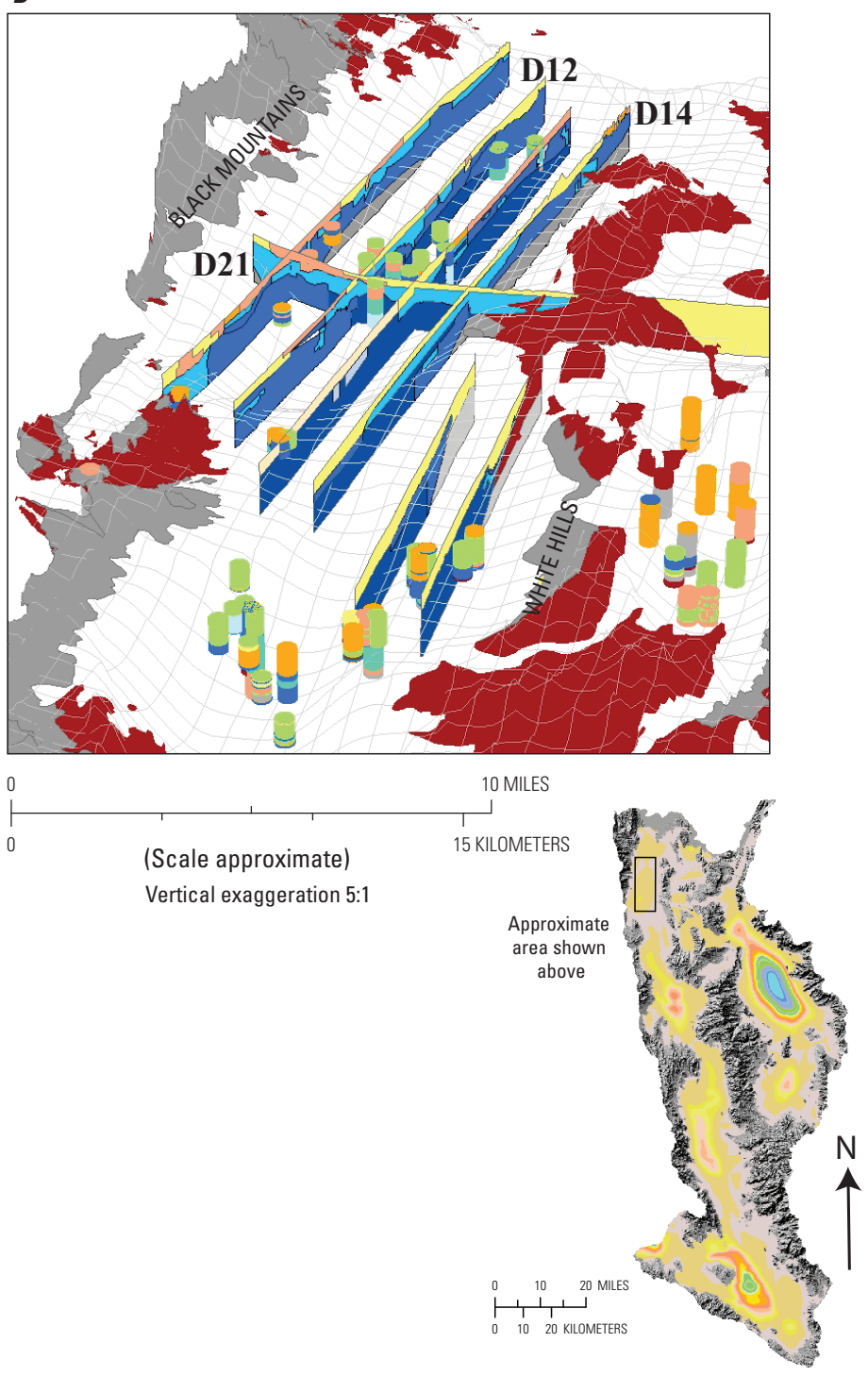

\section{EXPLANATION}

TRANSIENT ELECTROMAGNETIC RESISTIVITY VALUES

IN OHM-METERS (fig. 18A)

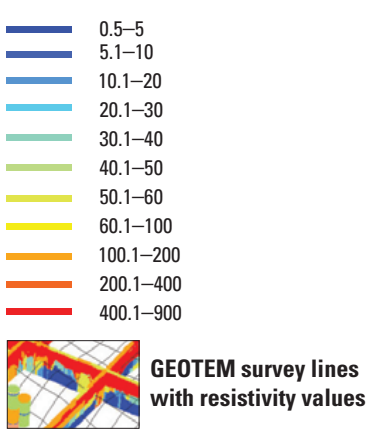

LITHOLOGIC UNITS, FROM

INTERPRETED RESISTIVITY (fig. 18B)

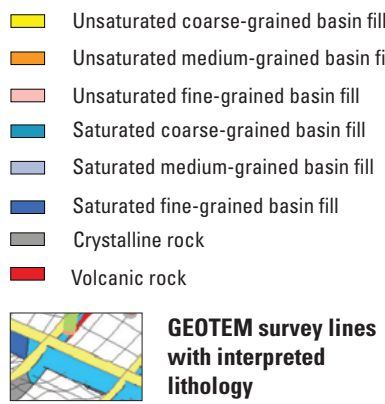

LITHOLOGY, FROM WELL LOGS

(figs. $18 A$ and $B$ )

$\square$ Coarse-grained sediments

$\square$ Medium-grained sediments

$\square$ Evaporite

$\square$ Fine-grained sediments

$\square$ Indurated sediments

$\square \quad$ Undifferentiated sediments

$\square$ Crystalline rocks

$\square$ Volcanic rocks

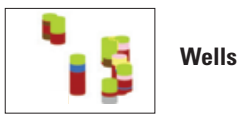

BEDROCK LITHOLOGY, FROM GEOLOGIC MAP

Volcanic rocks

$\square \quad$ Crystalline rocks

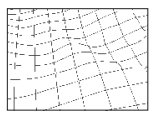

Basin geometry model

Figure 18. Mohave County, northwest Arizona, showing perspective view to the northeast of uninterpreted $(A)$ and interpreted $(B)$ resistivity from GEOTEM profiles in northern Detrital subbasin of the Detrital Valley basin. Profiles are numbered in the same order as in figure 11. 

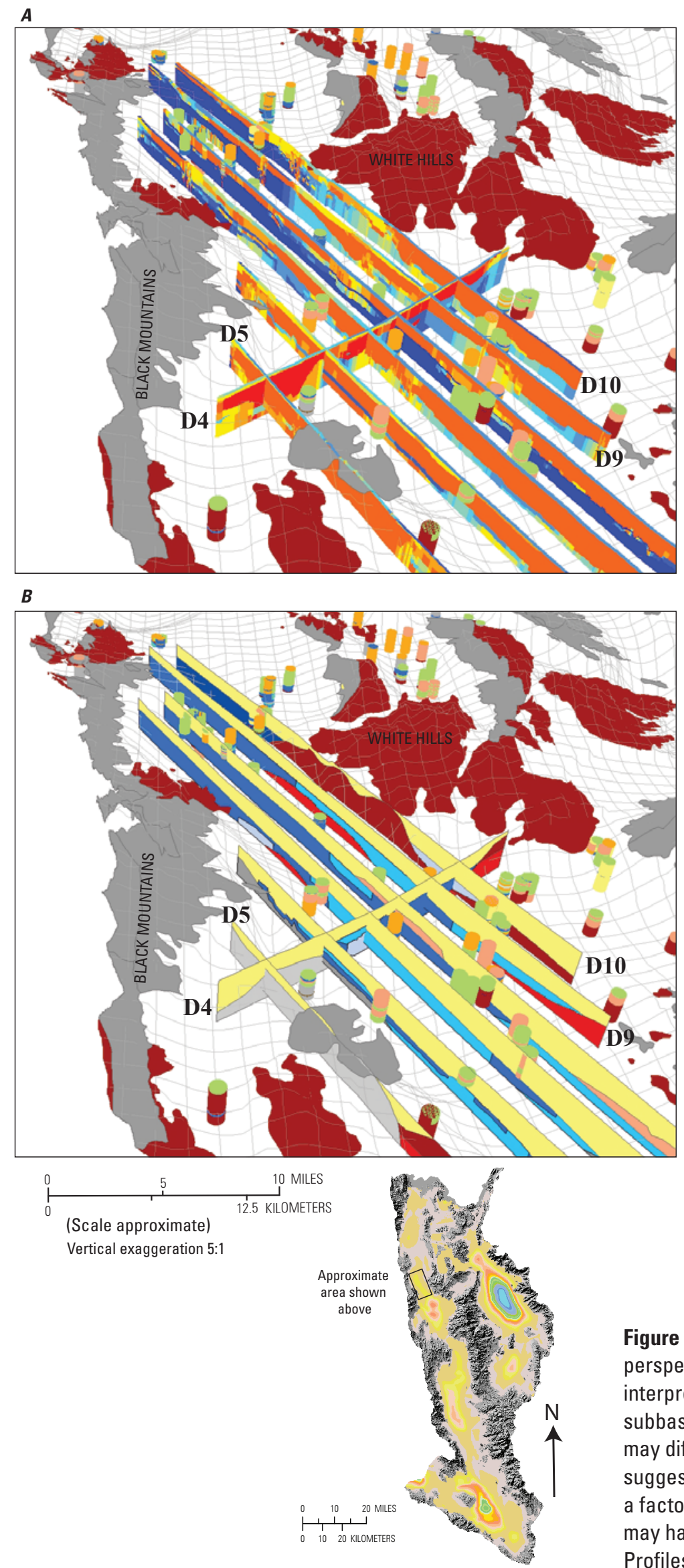

\section{EXPLANATION}

TRANSIENT ELECTROMAGNETIC RESISTIVITY VALUES,

IN OHM-METERS (fig. 19A)

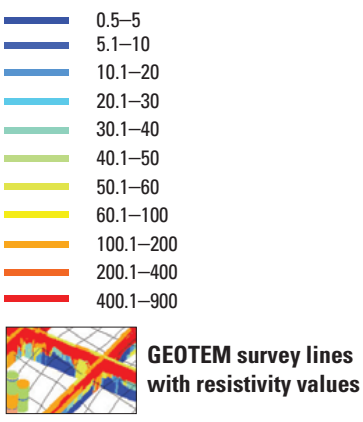

LITHOLOGIC UNITS, INTERPRETED FROM RESISTIVITY; (fig. 19B)

$$
\begin{array}{ll}
\square & \text { Unsaturated coarse-grained basin fill } \\
\square & \text { Unsaturated medium-grained basin fill } \\
\square & \text { Unsaturated fine-grained basin fill } \\
\square & \text { Saturated coarse-grained basin fill } \\
\square & \text { Saturated medium-grained basin fill } \\
\square & \text { Saturated fine-grained basin fill } \\
\square & \text { Crystalline rock } \\
\square & \text { Volcanic rock }
\end{array}
$$

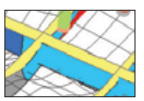

GEOTEM survey lines with interpreted lithology

\section{LITHOLOGY, FROM WELL LOGS \\ $\square$ Coarse-grained sediments \\ $\square \quad$ Medium-grained sediments \\ $\square$ Evaporite \\ $\square$ Fine-grained sediments \\ $\square$ Indurated sediments \\ $\square \quad$ Undifferentiated sediments \\ $\square$ Crystalline rocks \\ Volcanic rocks

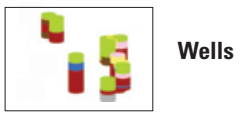 \\ BEDROCK LITHOLOGY, FROM GEOLOGIC MAP

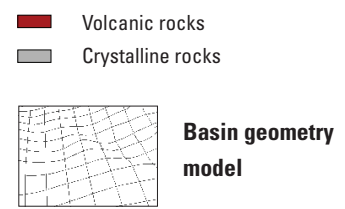

Figure 19. Mohave County, northwest Arizona, showing perspective view to the northeast of uninterpreted $(A)$ and interpreted $(B)$ resistivity from GEOTEM profiles in the central subbasin in Detrital Valley basin. Interpretation of the resistivity may differ along profiles that are perpendicular to one another, suggesting that the basin fill may be interlayered and (or) may be a factor of resistivity modeling where some surface interference may have occurred, or overlying lithology attenuated the signal. Profiles are numbered in the same order as in figure 11. 


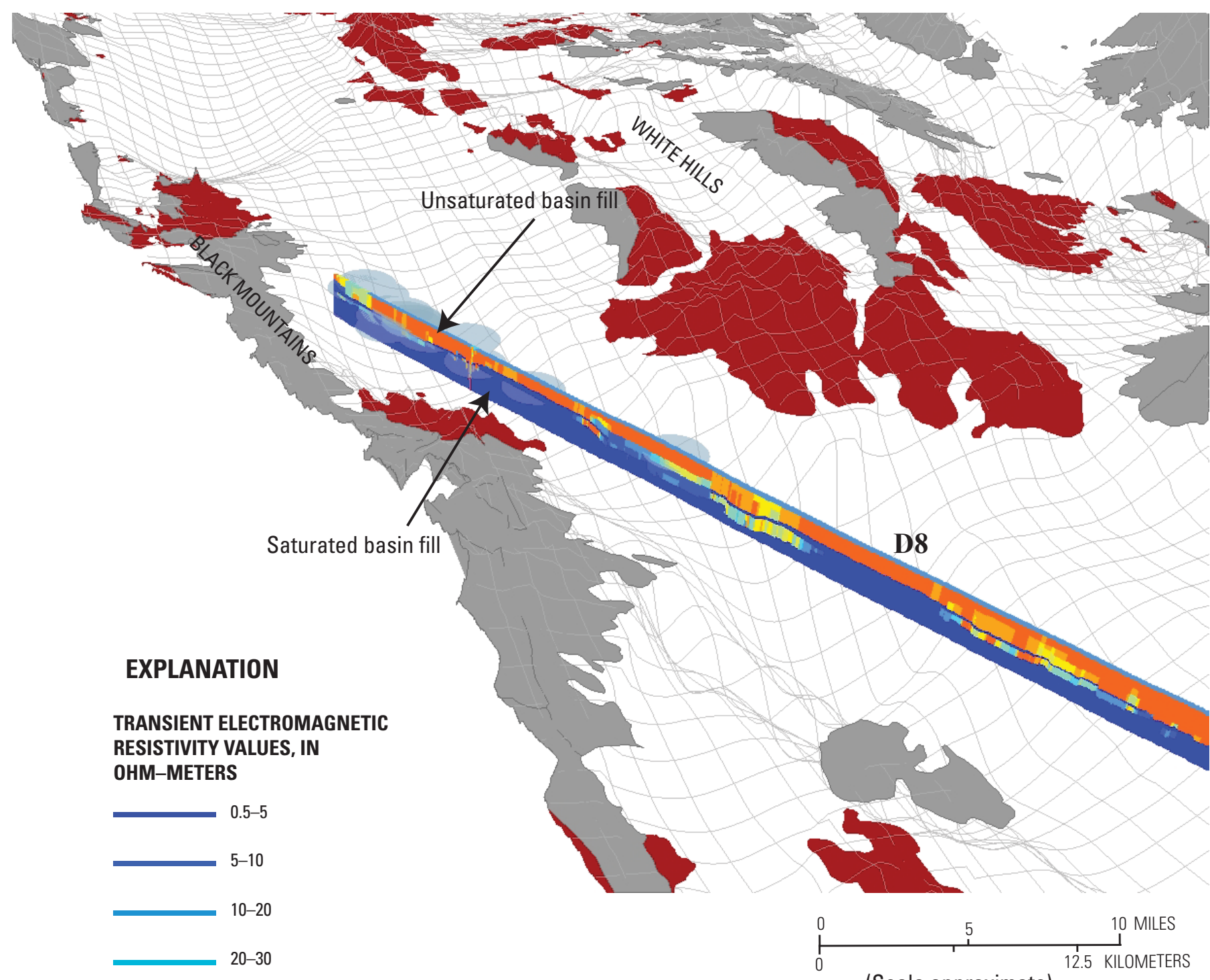

\section{TRANSIENT ELECTROMAGNETIC RESISTIVITY VALUES, IN OHM-METERS}
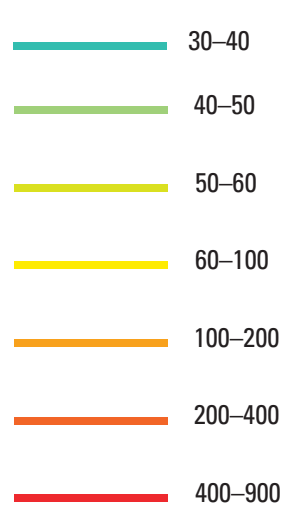

Water level

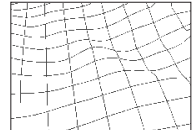

Basin geometry model

\section{BEDROCK LITHOLOGY FROM GEOLOGIC MAP}

$\square$ Volcanic rocks

$\square \quad$ Crystalline rocks

Figure 20. Mohave County, northwest Arizona, perspective view to the northwest, showing vertical changes in resistivity with depth from unsaturated to saturated basin fill on GEOTEM profile D8, overlain on the basin geometry model in the central Detrital subbasin of the Detrital Valley basin. Profile is numbered as in figure 11.

(Scale approximate) Vertical exaggeration 5:1

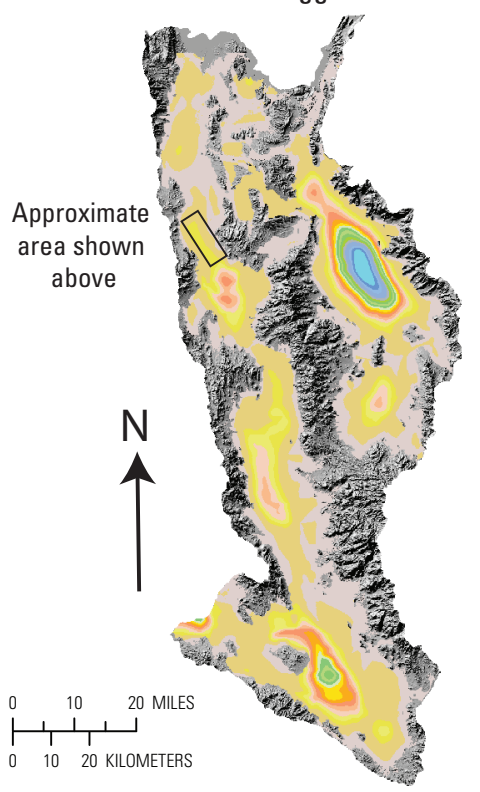


by Langenheim and others (2010), which estimates a depth of 3,500 m bls, suggests that the basin is an east-tilted halfgraben controlled by a fault on the east.

Well-log lithologic data support interpreting the resistivities ranging from 50 to $200 \Omega \cdot \mathrm{m}$ in the upper 300 to $400 \mathrm{~m}$ bls as alluvial-fan deposits, including sand and gravel and interlayered fine-grained clay, silt, and sand units as much as about $100 \mathrm{~m}$ thick (fig. 21). However, the absence of wells deeper than $400 \mathrm{~m}$ bls makes it difficult to interpret the deposits in the lower part of the subbasin.

Groundwater elevation indicates a groundwater divide within the southern Detrital subbasins (Anning and others, 2007). Water moves from the groundwater divide both northward into the central Detrital subbasin and southward into the Sacramento Valley basin (Anning and others, 2007). The depth to water is 200 to $250 \mathrm{~m}$ bls, without any sharp distinction between unsaturated and saturated basin fill as in the central Detrital subbasin. Water-quality data (Towne and Stephenson, 2003) reveal no elevated concentrations of sodium, chloride, or sulfate in the subbasin, suggesting the absence of evaporite deposits in the subsurface.

\section{Sacramento Valley Basin}

The Sacramento Valley basin comprises three subbasins on the basis of the basin geometry model: the Chloride, Golden Valley, and Dutch Flat subbasins (fig. 9). Interpretation of resistivity profiles and well-log lithologic data indicate fine- to coarse-grained clastic alluvial-fan deposits underlain by volcanic and crystalline bedrock. Unlike the Hualapai Valley and Detrital Valley basins, Sacramento Valley basin has no known playa evaporite or salt deposits.

\section{Chloride Subbasin}

The basin geometry model estimates that the depth of the Chloride subbasin is $900 \mathrm{~m}$ bls (fig. 9), consistent with the estimate of $975 \mathrm{~m}$ bls by Conway and Ivanich (2008). The subbasin is narrow, bounded on the west by volcanic bedrock and on the east by crystalline bedrock and the Chloride Fault. The Sacramento Valley basin is likely an east-tilted halfgraben; however, the basin geometry model also indicates a steep margin along the west side of the valley basin. The west side may also be fault controlled, suggesting that the Chloride subbasin is either a graben or an abrupt variation in rock densities from fine-grained deposits to coarse-grained alluvial-fan deposits (Beard and others, 2011).

Interpretation of resistivity profiles in the Chloride subbasin were complicated in several areas by electromagnetic interference from housing developments. Broad interpretation of resistivity profiles, water levels, and limited well-log lithologic data suggest unsaturated coarse-grained alluvial fan deposits with resistivities greater than $100 \Omega \cdot \mathrm{m}$ overlie undifferentiated mostly fine- to medium-grained deposits with resistivities of 1 to $30 \Omega \cdot \mathrm{m}$ (fig. 22 ).
Groundwater moves from the southern Detrital subbasin southward into the Chloride subbasin (Anning and others, 2007). The groundwater surface indicates a fairly steep hydraulic gradient through the narrow bedrock boundaries of the Chloride subbasin between the towns of Santa Claus and Golden Valley (figs. 1 and 3). The depth to water is 250 to 320 $\mathrm{m}$ bls in wells drilled near the center of the subbasin.

\section{Golden Valley Subbasin}

The basin geometry model estimates the depth of the Golden Valley subbasin to be 1,300 m bls (fig. 9). Conway and Ivanich (2008) estimated its depth at $1,800 \mathrm{~m}$ bls and Langenheim and others (2010) suggested a depth of as much as $3,000 \mathrm{~m}$ bls.

Generally unsaturated, coarse-grained basin fill deposits with resistivities greater than $100 \Omega \cdot \mathrm{m}$ form the subbasin surface. Saturated coarse-grained basin fill with resistivities 50 to $100 \Omega \cdot \mathrm{m}$ overlies fine-grained deposits with resistivities 1 to $20 \Omega \cdot \mathrm{m}$ in the central and southern parts of the subbasin (fig. 23). Well-log lithologic data typically describe undifferentiated medium- to coarse-grained basin fill interbedded with fine-grained deposits.

The Golden Valley subbasin is most likely floored by a west-dipping sequence of volcanic rocks about 0.5 to at least $1 \mathrm{~km}$ thick; however, only a few well logs suggest the presence of volcanic rocks in the subsurface below the water table. In the absence of well-log lithologic data, resistivity profiles along the east side of the subbasin were interpreted to indicate volcanic rocks in areas of subhorizontal layers and (or) successive vertical changes in resistivity generally from 30 to $100 \Omega \cdot \mathrm{m}$.

The groundwater hydraulic gradient is low as the water moves from north to south; the depth to water is 140 to $250 \mathrm{~m}$ bls (Anning and others, 2007). The lateral and vertical extents of the saturated basin fill appear to decrease in the southern part of the subbasin where volcanic rocks overlie crystalline rocks (fig. 23).

\section{Dutch Flat Subbasin}

The basin geometry model estimates the depth of the Dutch Flat subbasin to be $2,600 \mathrm{~m}$ bls. The subbasin is believed to be controlled by the Buck Mountain Fault on the southwest and the inferred Dutch Flat Fault on the northeast side, suggesting that this subbasin may be a graben or modified half-graben, with the larger-displacement fault on the southwest side (figs. 3 and 9; Beard and others, 2011). Little is known about the Dutch Flat subbasin and very few subsurface data are available to identify sedimentary types.

Basin fill deposits in the Dutch Flat subbasin are characterized by an alluvial-fan depositional environment. A few wells that penetrate only the very top several hundred meters below land surface in the subbasin suggest interlayers of clays, sands, and gravels. Resistivity profiles were flown 


\section{A}

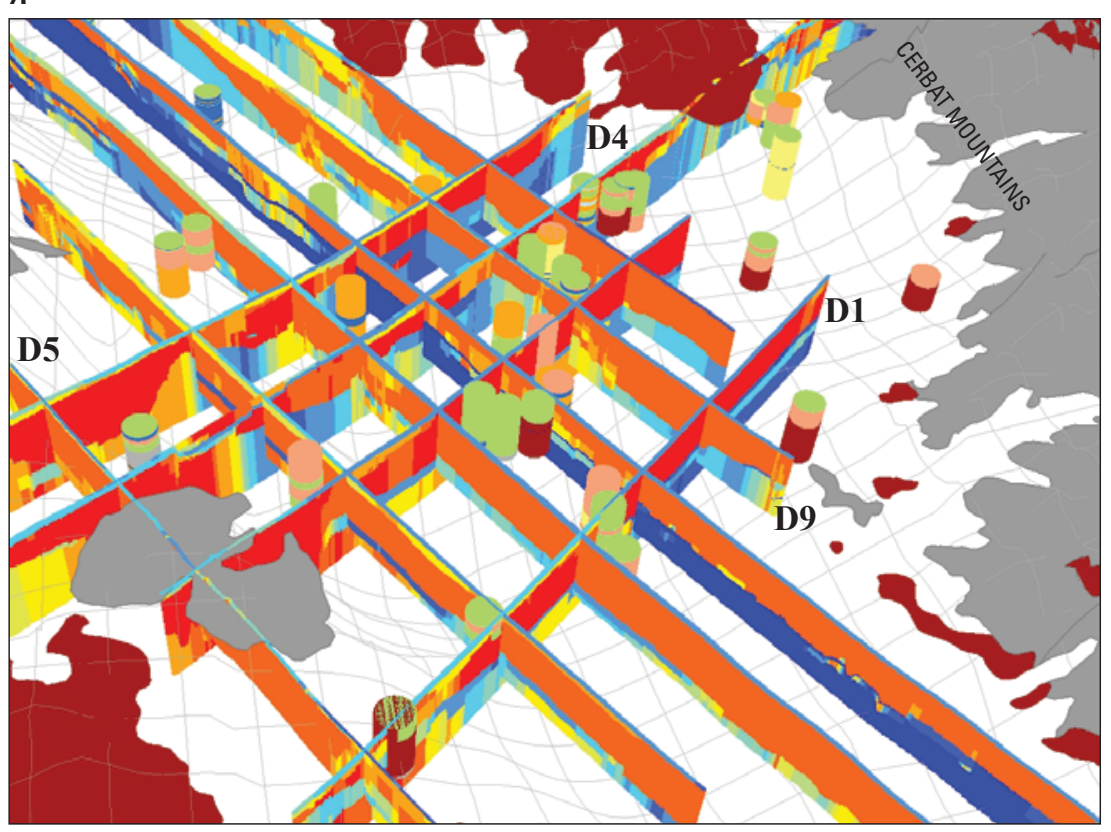

B
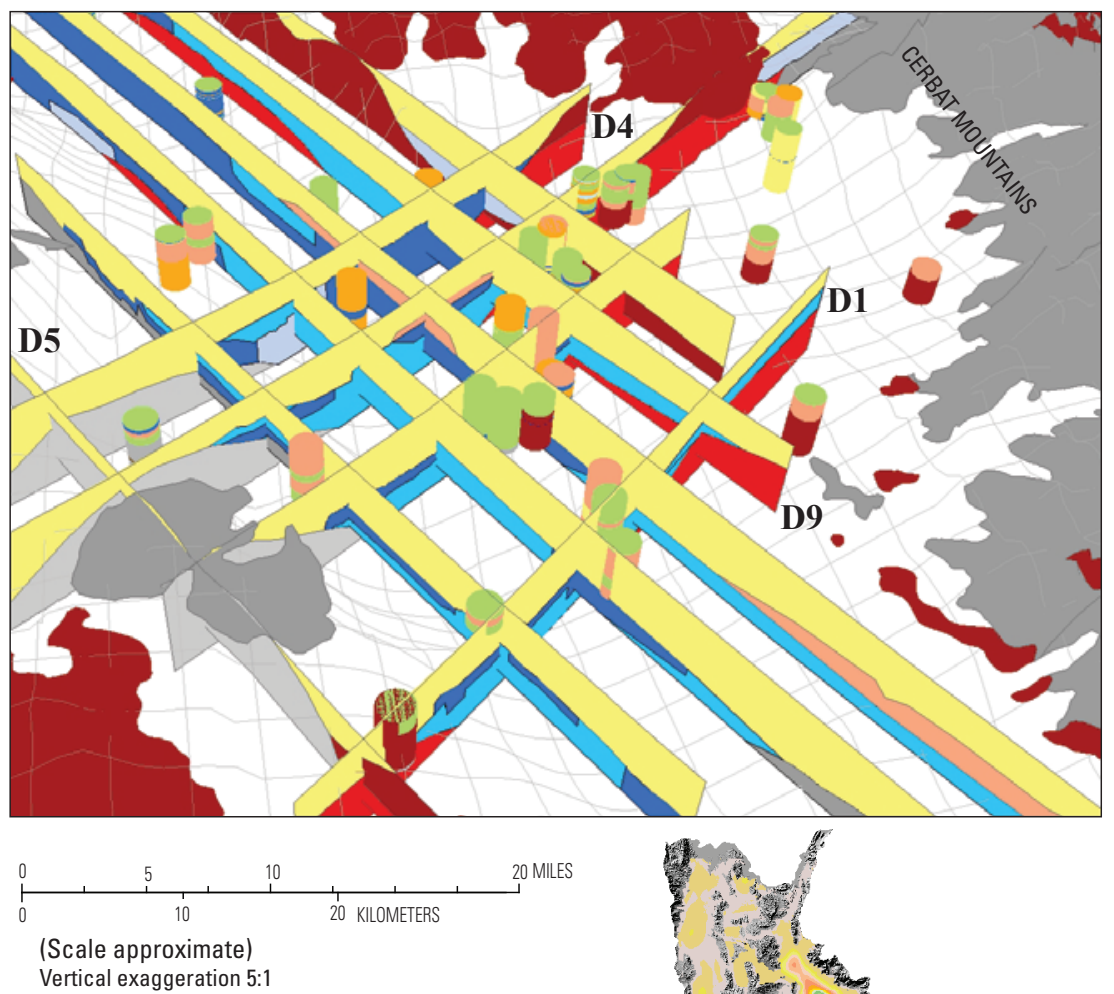

Vertical exaggeration 5:1

\section{EXPLANATION}

TRANSIENT ELECTROMAGNETIC

RESISTIVITY VALUES, IN

OHM-METERS (fig. 21A)

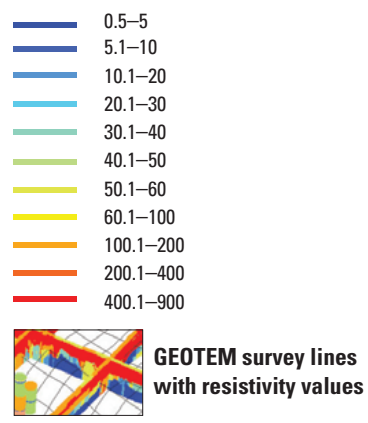

LITHOLOGIC UNITS, FROM

INTERPRETED RESISTIVITY (fig. 21B)

$\square$ Unsaturated coarse-grained basin fill

$\square \quad$ Unsaturated medium-grained basin fill

$\square$ Unsaturated fine-grained basin fill

$\square$ Saturated coarse-grained basin fill

$\square$ Saturated medium-grained basin fill

$\square$ Saturated fine-grained basin fill

$\square$ Crystalline rock

$\square$ Volcanic rock

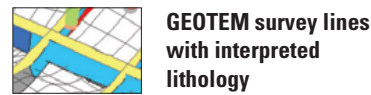

\section{LITHOLOGY, FROM WELL LOGS}

(figs. 21 $A$ and $B$ )

$\square \quad$ Coarse-grained sediments

$\square$ Medium-grained sediments

$\square$ Evaporite

$\square$ Fine-grained sediments

$\square \quad$ Indurated sediments

$\square$ Undifferentiated sediments

$\square$ Crystalline rocks

$\square$ Volcanic rocks

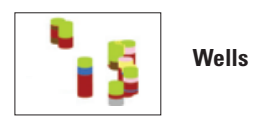

\section{BEDROCK LITHOLOGY,}

FROM GEOLOGIC MAP

Volcanic rocks

$\square \quad$ Crystalline rocks

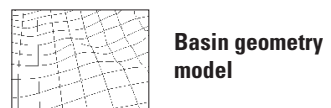

Figure 21. Mohave County, northwest Arizona, showing perspective view to the northeast of uninterpreted $(A)$ and interpreted resistivity $(B)$ from GEOTEM profiles in the southern Detrital subbasin in Detrital Valley basin. Interpretation of resistivity may differ along profiles that are perpendicular to one another, suggesting that the basin fill may be interlayered and (or) a factor of the resistivity modeling where some surface interference may have occurred or overlying lithology attenuated signal. Profiles are numbered in the same order as in figure 11. 


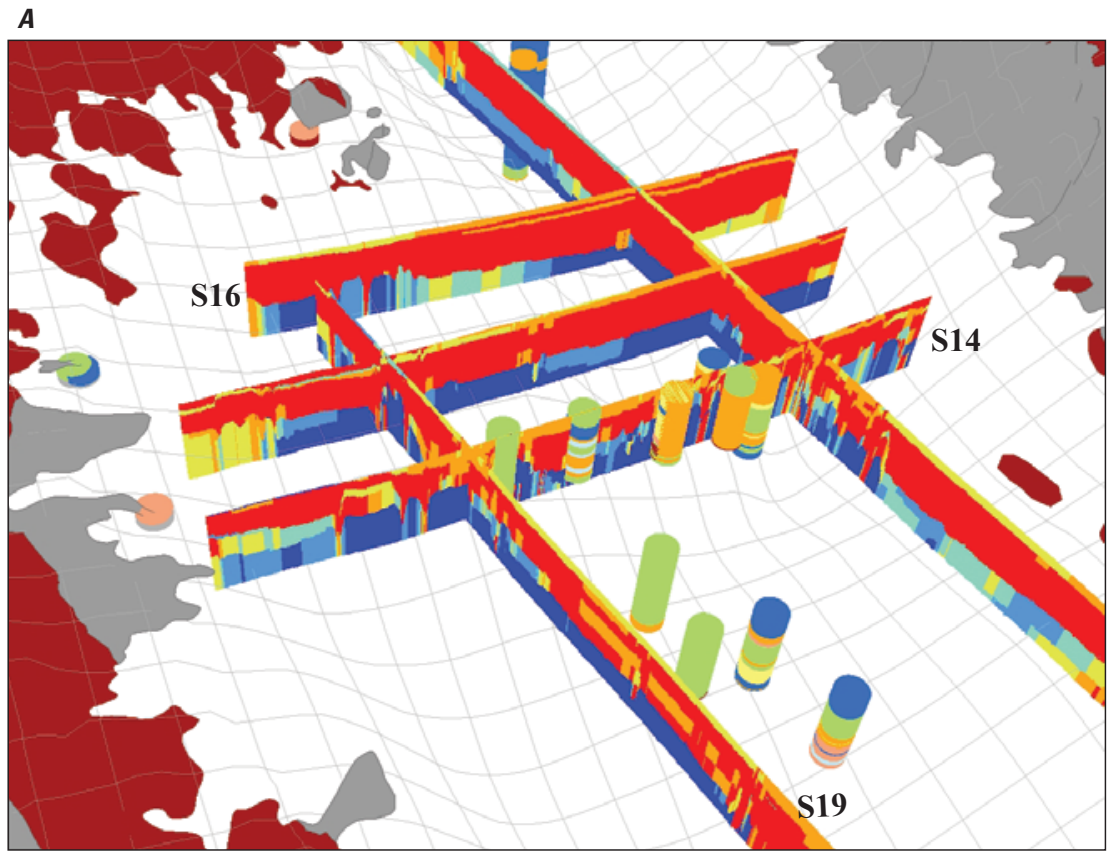

B
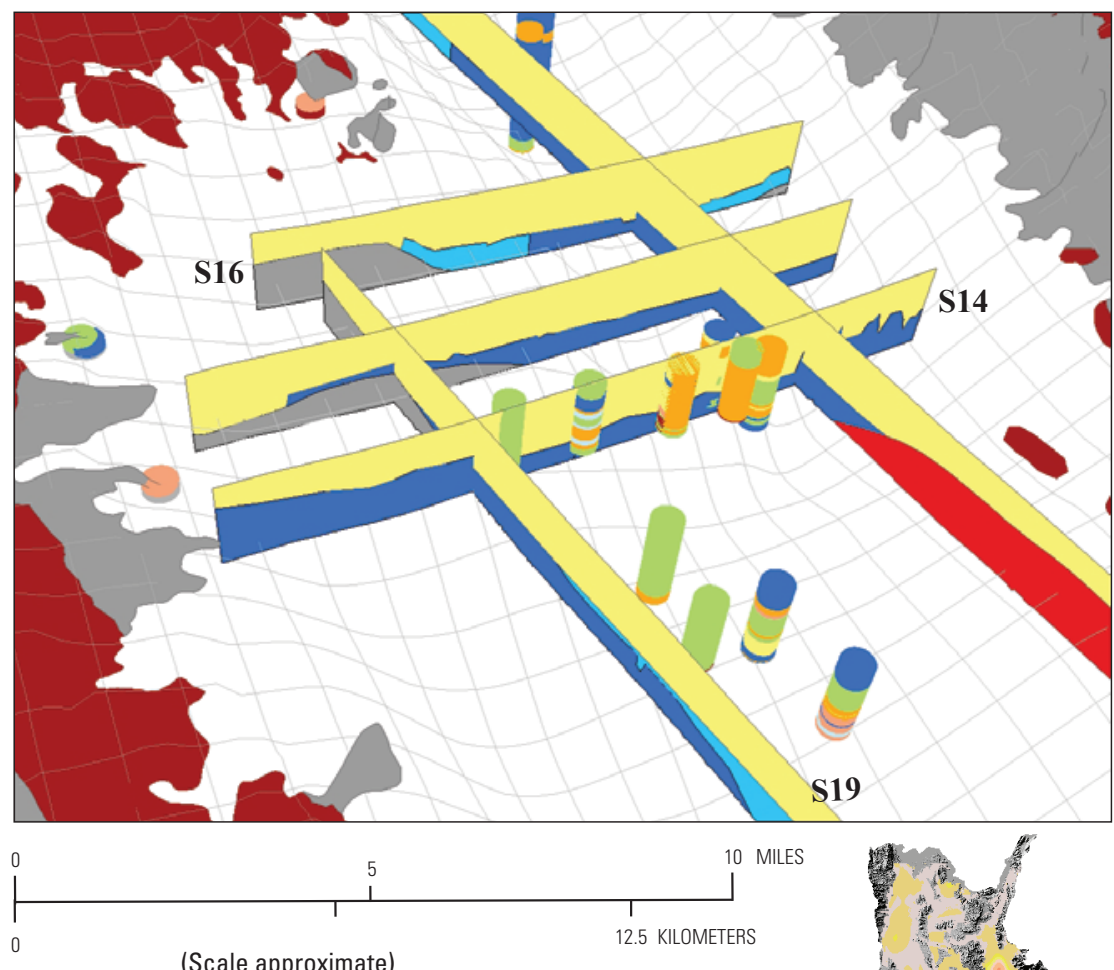

pproximate)

Vertical exaggeration 5:1

Figure 22. Mohave County, northwest Arizona, showing perspective view to the northeast of uninterpreted $(A)$ and interpreted $(B)$ resistivity for GEOTEM profiles in the Chloride subbasin of the Sacramento Valley basin. Profiles are numbered in the same order as in figure 11.

\section{EXPLANATION}

TRANSIENT ELECTROMAGNETIC

RESISTIVITY VALUES, IN

OHM METERS (fig. 22A)

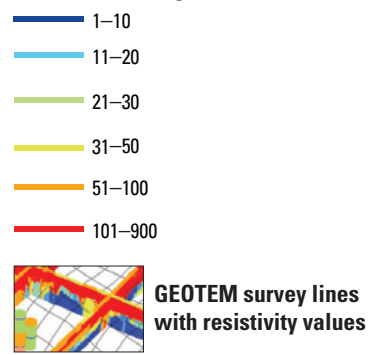

LITHOLOGIC UNITS, FROM

INTERPRETED RESISTIVITY (fig. 22B)

$\square$ Unsaturated coarse-grained basin fill

$\square$ Unsaturated medium-grained basin fill

$\square$ Unsaturated fine-grained basin fill

$\square$ Saturated coarse-grained basin fill

$\square$ Saturated medium-grained basin fill

- Saturated fine-grained basin fill

$\square$ Crystalline rock

$\square$ Volcanic rock

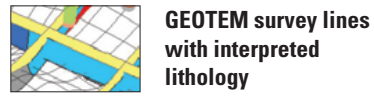

LITHOLOGY, FROM WELL LOGS (figs. 21 $A$ and $B$ )

$\square$ Coarse-grained sediments

$\square$ Medium-grained sediments

$\square$ Evaporite

- Fine-grained sediments

$\square$ Indurated sediments

$\square$ Undifferentiated sediments

$\square$ Crystalline rocks

Volcanic rocks

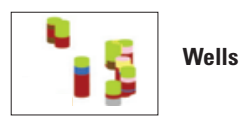

BEDROCK LITHOLOGY, FROM GEOLOGIC MAP

- Volcanic rocks

$\square$ Crystalline rocks

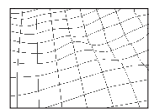

Basin geometry model 

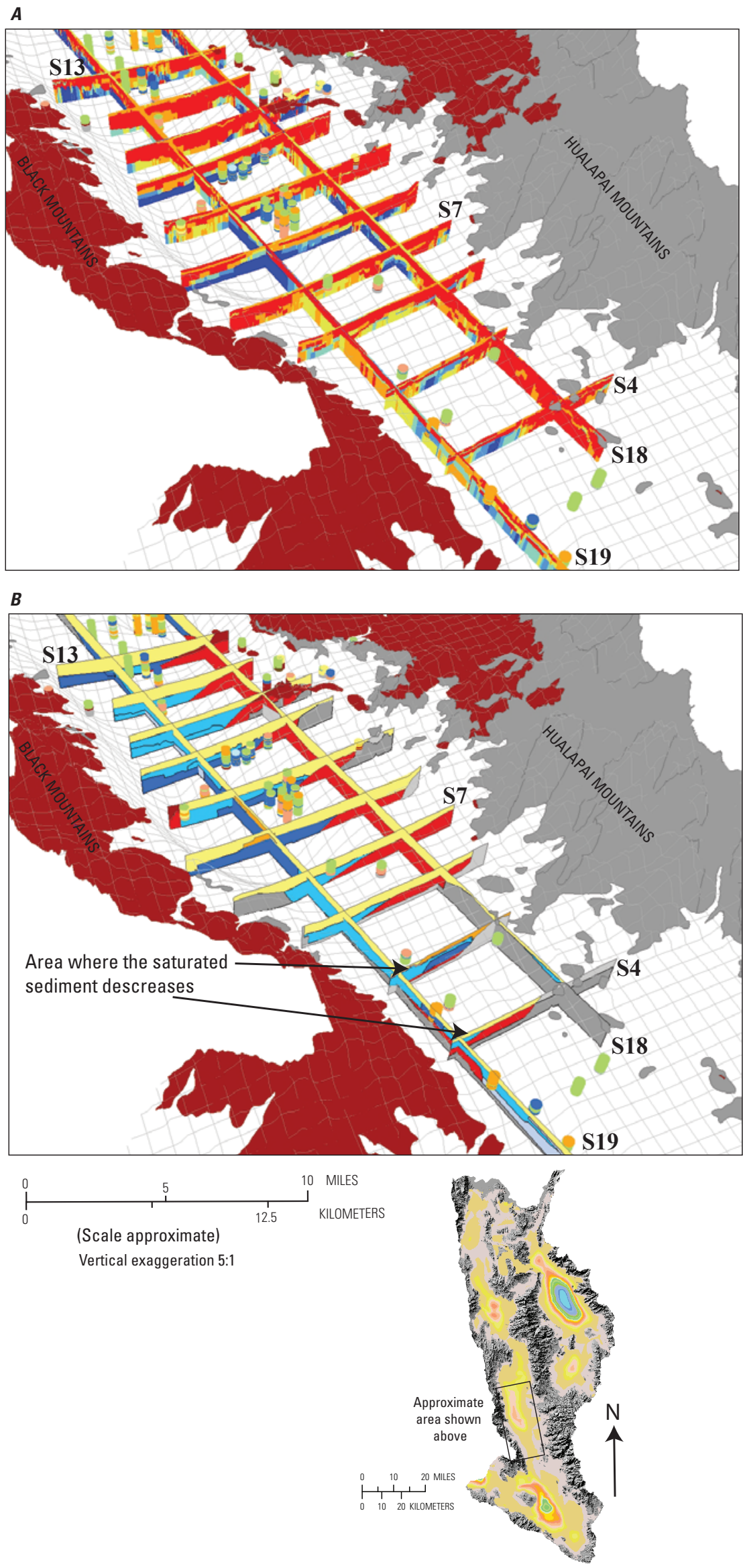

\section{EXPLANATION}

TRANSIENT ELECTROMAGNETIC

RESISTIVITY VALUES, IN

OHM-METERS (fig. 23A)

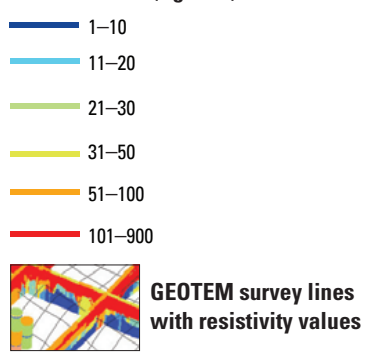

LITHOLOGIC UNITS,

FROM INTERPRETED RESISTIVITY (fig. 23B)

$\square$ Unsaturated coarse-grained basin fill

$\square$ Unsaturated medium-grained basin fill

$\square$ Unsaturated fine-grained basin fill

$\square$ Saturated coarse-grained basin fill

$\square \quad$ Saturated medium-grained basin fill

$\square$ Saturated fine-grained basin fill

$\square$ Crystalline rock

Volcanic rock

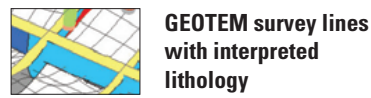

\section{LITHOLOGY, FROM WELL LOGS}

$\square$ Coarse-grained sediments

$\square$ Medium-grained sediments

$\square$ Evaporite

$\square$ Fine-grained sediments

$\square \quad$ Indurated sediments

$\square$ Undifferentiated sediments

$\square$ Crystalline rocks

$\square$ Volcanic rocks

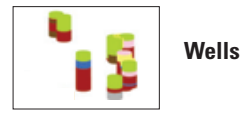

\section{BEDROCK LITHOLOGY,}

FROM GEOLOGIC MAP

Volcanic rocks

$\square \quad$ Crystalline rocks

\section{Basin geometry} model
Figure 23. Mohave County, northwest Arizona, showing perspective view to the northeast of uninterpreted $(A)$ and interpreted $(B)$ resistivity for GEOTEM profiles in Golden Valley subbasin of the Sacramento Valley basin. Profiles are numbered in the same order as in figure 11. 
only over the northern part of the subbasin. The fine-grained basin fill inferred from resistivity profiles overlies the bedrock between the northern part of the Dutch Flat subbasin and the Golden Valley subbasin. Well-log lithologic data and resistivities of 1 to $30 \Omega \cdot \mathrm{m}$ suggest saturated fine- to medium-grained deposits overlain by unsaturated fine- to coarse-grained indurated deposits (fig. 24) within the limited area covered by resistivity profiles.

Groundwater in the Dutch Flat subbasin moves from the north and east sides and discharges into the Colorado River west of the town of Topock (Anning and others, 2007). The hydraulic gradient is shallow in the eastern part of the subbasin and steepens westward through the medium- to coarsegrained basin fill between the mountains.

\section{Groundwater Storage}

The hydrogeologic framework and datasets provide an understanding of the extent and spatial distribution of dry sediment deposits within the basin fill aquifer, and therefore were the foundation for estimating the volume of groundwater stored in the basin fill aquifers in the Hualapai Valley, Detrital Valley, and Sacramento Valley basins. This volume depends on the spatial extent of these aquifers and the distribution of specific yield within them, where "specific yield" can be defined as the portion of water stored in the aquifer pore space that can be drained owing to reduced hydraulic head. Specific yield depends on the texture and porosity of the basin fill aquifer, and so estimates of the volume of stored groundwater depend not only on the extent of the basin fill aquifers but also on the spatial distribution of sedimentary grain sizes.

The storage estimates presented here are of the volume of groundwater that the basin fill aquifers will yield to a depth of $400 \mathrm{~m}$ bls for the whole valley basin, as well as for specific hydrogeologic units (HGUs). These estimates of groundwater storage are cautious and do not take into account many other factors that limit the volume of water actually available. Alley (2007) discussed how aquifer permeability, water quality, and the cost of well drilling, are among the factors that limit the volume of water actually available in practice.

\section{Construction of the Groundwater Storage Model}

We constructed the groundwater-storage model by first defining four HGUs within the saturated basin-fill with different sediment characteristics. Using information from the hydrogeologic framework, we delineated the spatial extent of HGUs within the valley basins so that the volume for each HGU could be calculated for each valley basin. Then, using an assigned percentage of specific yield for each HGU, we determined the volume of groundwater that could be obtained from aquifer storage. The boundary of the model was defined by using the ADWR groundwater-basin boundaries for the Hualapai Valley, Detrital Valley, and Sacramento Valley basins, assuming that the aquifers (to $400 \mathrm{~m}$ bls) were primarily unconfined within all three valley basins.

The four HGUs defined for estimating groundwater storage are distinguishable on the basis of grain-size characteristics and the uncertainty of their spatial extent within each valley.

1. Saturated coarse-grained basin fill (SCBF) consists primarily of sand, gravel, and cobble with lesser amounts of finer-grained deposits. This HGU directly corresponds to the saturated coarse-grained basin fill and medium-grained basin fill described in the hydrogeologic framework (table 3). The extent of this HGU is well known from the hydrogeologic framework, as discussed in the previous section.

2. Saturated fine-grained basin fill (SFBF) consists primarily of silt and clay, with lesser amounts of coarser-grained deposits. This HGU directly corresponds to the saturated fine-grained basin fill described in the hydrogeologic framework (table 3 ). The extent of this HGU is well known from the hydrogeologic framework as discussed in the previous section.

3. Saturated undifferentiated unconsolidated basin fill (UUBF) consists of both fine- and coarse-grained basin fill. The extent of this HGU is well defined from the interpreted resistivity surveys and well logs. Sedimentary texture, however, is undifferentiated because of lateral or vertical transitions between deposits within a short distance, such as interbedding, or because the hydrogeologic framework, especially the interpreted resistivity profiles or well-log lithologic data, is less definitive about grain size.

4. Saturated poorly characterized basin fill (PCBF) represents subsurface sedimentary deposits where saturated basin fill is believed to occur but both grain size and extent are poorly characterized because the hydrogeologic framework, especially the interpreted resistivity profiles, well-log lithologic data, and water-level data, are generally sparse and (or) less definitive in these areas.

The spatial delineation of the four HGUs within each valley basin was based on analysis and interpretation of geologic information, well-log lithologic data, the basin geometry model, interpreted resistivity profiles, water-level data and topographic data that were used in constructing the hydrogeologic framework. These data were used in the following ways for the groundwater-storage model:

- Geologic information - the units on the 1:250,000scale geologic map (Beard and others, 2011) are correlated with the lithologic description (tables 1 and 3 ), allowing the use of data from the geologic map to identify the extent of HGUs on the land surface and to infer their distribution in the shallow subsurface. 


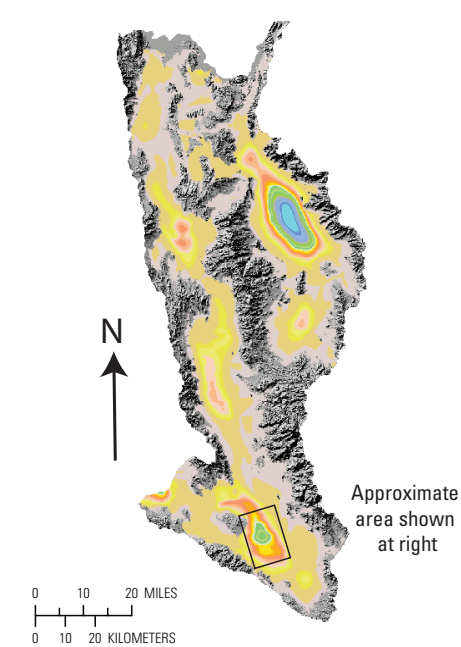

EXPLANATION

TRANSIENT ELECTROMAGNETIC RESISTIVITY VALUES, IN OHM-METERS (fig. 24A)

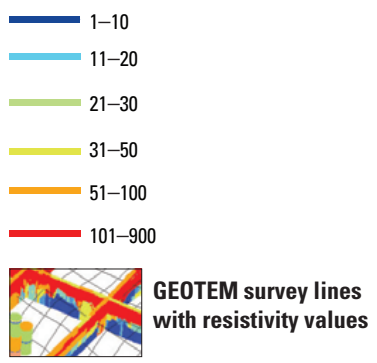

LITHOLOGIC UNITS, FROM INTERPRETED RESISTIVITY (fig. 24B)

$\square \quad$ Unsaturated coarse-grained basin fil

$\square$ Unsaturated medium-grained basin fill

$\square$ Unsaturated fine-grained basin fill

$\square$ Saturated coarse-grained basin fill

$\square$ Saturated medium-grained basin fill

$\square$ Saturated fine-grained basin fill

$\square \quad$ Crystalline rock

$\square$ Volcanic rock

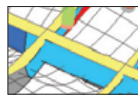

GEOTEM survey lines with interpreted lithology

\section{LITHOLOGY, FROM WELL LOGS}

\footnotetext{
$\square \quad$ Coarse-grained sediments

$\square$ Medium-grained sediments

$\square$ Evaporite

Fine-grained sediments

$\square$ Indurated sediments

$\square$ Undifferentiated sediments

Undifferentiated rock

$\square$ Crystalline rocks

Volcanic rocks
}

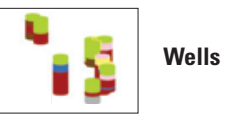

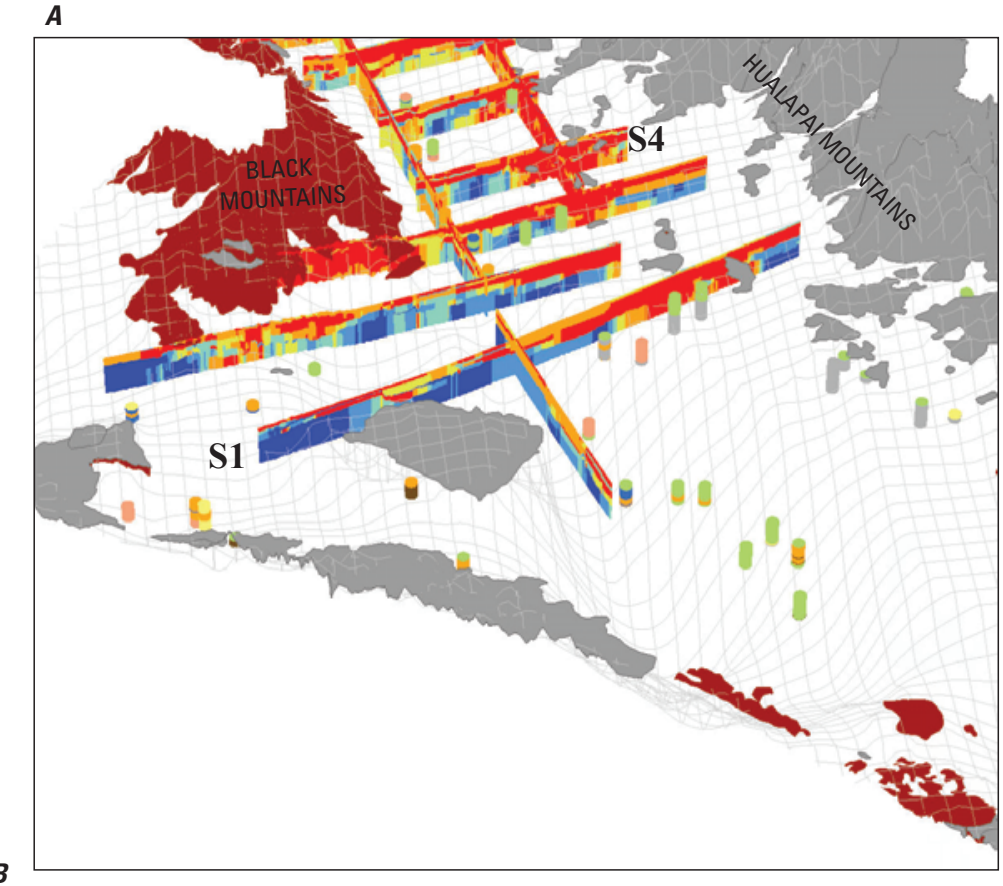

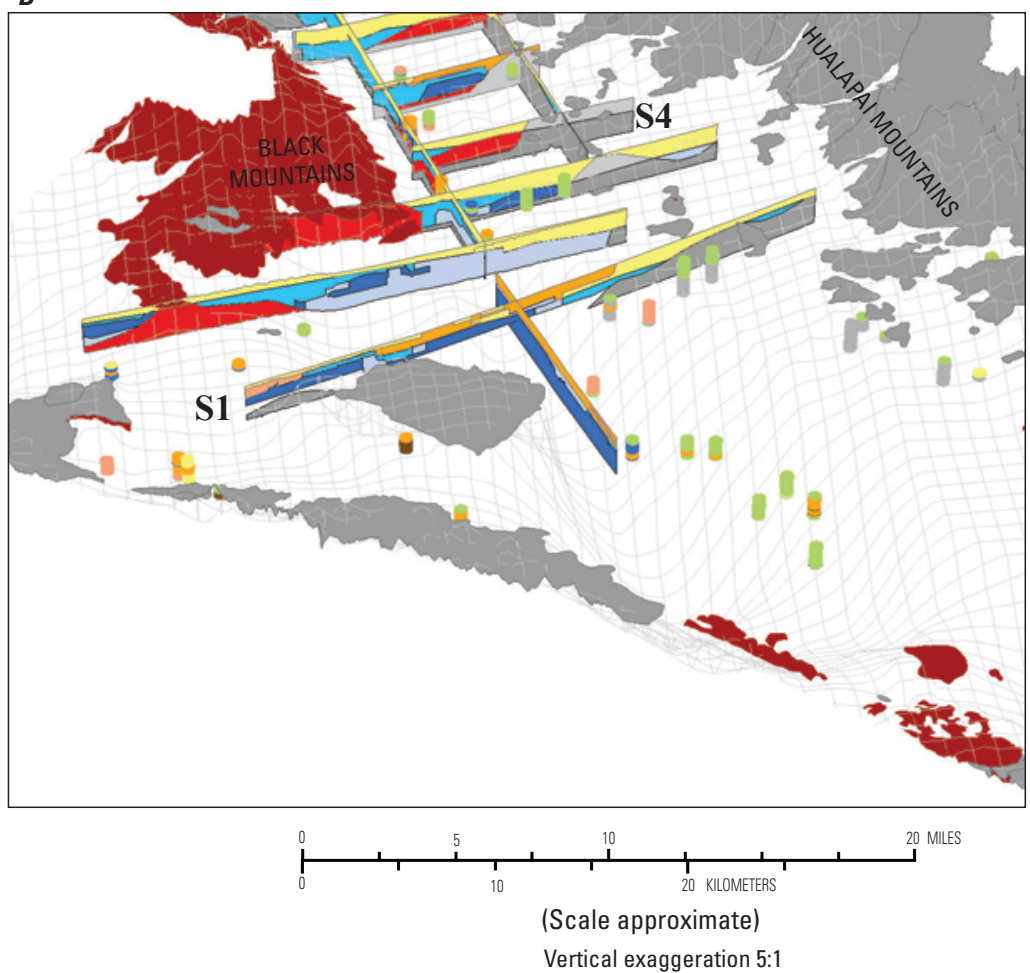

BEDROCK LITHOLOGY, FROM GEOLOGIC MAP

$\square$ Volcanic rocks

$\square$ Crystalline rocks

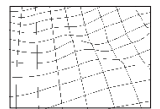

Basin geometry

model
Figure 24. Mohave County, northwest Arizona, showing perspective view to the northeast of uninterpreted $(A)$ and interpreted $(B)$ resistivity from GEOTEM profiles in the Dutch Flat subbasin of the Sacramento Valley basin. Profiles are numbered in the same order as in figure 11. 
- Well-log lithology data - the tops and bottoms of vertical intervals were assigned a simplified lithologic attribute on the basis of the lithologic description from the well log, along with altitudes based on the elevation of the well at the land surface and depth along the well log. The vertical intervals were used to approximate sedimentary type and bedrock contacts in areas between the interpreted resistivity profiles.

- Interpreted resistivity profiles - the interpreted resistivity profiles were one of the most important datasets in constructing the groundwater storage model because they provided information about basin fill textures that were used to estimate the approximate extent of the HGUs.

- Basin geometry model - the data from the basin geometry model included the contact between basin fill and the bedrock, and so these data were used to define the lower extent of HGUs in some areas.

- Water-level data-hydrologic data from the report by Anning and others (2007) were used to determine the boundary between saturated and unsaturated basin fills, and so these data helped define the upper extent of the HGUs.

- Topographic data-DEMs from the National Elevation Dataset (NED; U.S. Geological Survey, 2011) were used to constrain the HGUs to occur between the land surface and $400 \mathrm{~m}$ bls. Data were downloaded from the USGS Seamless Server in UTM projection zone 12, North American Datum 1983.

Spatial-extent delineation and volume estimation for the HGUs was completed by using spatial-analysis software. ArcGIS was used to integrate the geologic information, welllithologic data, the basin geometry model, and interpreted resistivity profiles from several different geodatabases. The ArcHydro Groundwater Subsurface Analyst software by Aquaveo was used to create gridded surfaces that connected the inferred saturated basin fill between resistivity profiles. Gridded surfaces were constructed to best approximate the upper and lower boundaries of an HGU. The upper boundary was constructed from the water-table-altitude data, and the lower surface from the altitude of the bottom of the inferred deposits. Grid cells within each surface were 10,000 square meters $\left(\mathrm{m}^{2}\right)$ ( $100 \mathrm{~m}$ by $100 \mathrm{~m}$ ) in area and snapped to the surface DEM to maintain alignment between each cell within each layer. The upper and lower grids for each HGU were clipped to the same area common to both grids. For each HGU, the lower grid was subtracted from the upper grid to determine the HGU thickness. The volume for each HGU in a basin was determined by multiplying the HGU thickness of each cell by the cell area. For each valley basin, the HGU volumes of each cell were summed for a total HGU volume in the basin. Groundwater storage was calculated by converting the volume in cubic meters calculated for each HGU to cubic kilometers and multiplying the HGU volumes by selected ratios of specific yield expressed as the fraction of drainable volume to total volume. Estimates of the storage volumes for each HGU were then added together for a valley basin total (table 4).

The specific yields were selected largely on the basis of the dominant grain size of basin fill in the HGUs. The heterogeneity of the basin fill in the Hualapai Valley, Detrital Valley, and Sacramento Valley basins precludes using available aquifer test data in the study area (fig. 1) because those data are few and highly site-specific, and cannot be adequately used to interpret storage properties for basin fill elsewhere (Garner and Truini, 2011). The SCBF HGU, which provides much of the groundwater to wells in the Sacramento Valley basin, typically produces potable water (fig. 25; Towne and others, 2001; Towne and Stephenson, 2003; and Towne and Rowe, 2007). Generally, this HGU is fairly permeable with an estimated hydraulic conductivity ranging from 0.23 to $1 \mathrm{~m}$ per day (Gillespie and Bentley, 1971), and so the SCBF HGU was assigned a specific yield of 25 percent.

The SFBF HGU consists of fine-grained alluvial/fluvial and playa deposits. In the Hualapai Valley basin, this HGU is a combination of older playa and fine-grained shoreline and valley-axial wash deposits, about 100 to $200 \mathrm{~m}$ thick. The HGU in the Hualapai subbasin below Red Lake playa and southward towards Long Mountain corresponds to mud and evaporitic playa deposits (fig. 25). In the Sacramento Valley basin, the SFBF HGU is a semi-impermeable layer, 200 to $300 \mathrm{~m}$ thick, that occurs beneath the SCBF HGU. The origin of SFBF HGU in Sacramento Valley basin is unknown but may represent playa and fluvial deposits and (or) weathered ash-flow tuff. Much of the groundwater, however, is retained within the basin fill and so the SFBF HGU was assigned a specific yield of 6 percent.

The UUBF HGU commonly consists of interlayered fine- and coarse-grained basin fill (fig. 25). The deposits are predominantly coarse grained in the Hualapai Valley and Sacramento Valley basins, whereas in the Detrital Valley basin they are predominantly fine grained. For the Hualapai Valley and Sacramento Valley basins, the HGU was assigned a specific yield of 15 percent; for the Detrital Valley basin, the HGU was assigned a specific yield of 8 percent to reflect the predominance of the fine-grained deposits. The sedimentary deposits within the PCBF HGU in the Detrital Valley basin are similar to those in the UUBF HGU in the Hualapai Valley and Sacramento Valley basins, and so they are likewise assigned a specific yield of 15 percent.

Groundwater-storage estimates generally have considerable uncertainty that results from propagation of statistical errors in the volume and specific yield estimates, and this uncertainty should be considered when using such estimates. Errors in volume estimates that result from errors in estimates of the saturated thickness and lateral extent of an HGU were qualitatively determined by using the expert opinion of the hydrogeologic-framework analyst regarding the uncertainty in these estimates. Errors in specific-yield estimates result from 


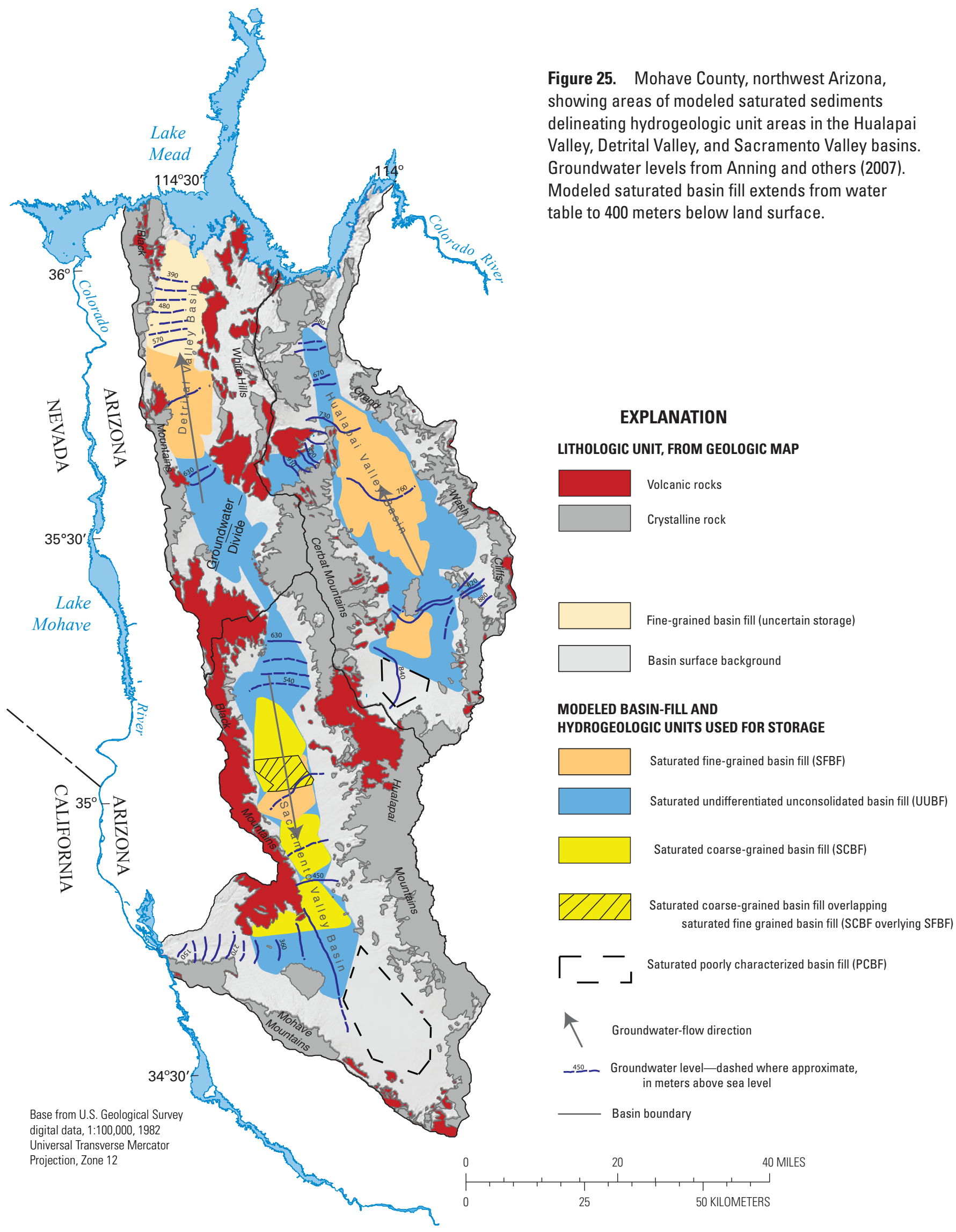


the spatial variation of specific yield within an HGU and from errors in selecting a representative specific yield for the HGU. As noted above, specific yields for each HGU were selected from the literature, and errors associated with these values were qualitatively determined as approximately equal to 25 percent of the range cited in the literature. The errors in volume and specific yield for each HGU were expressed as percentage errors and then combined into the percentage error for the HGU groundwater-storage estimate by taking the square root of the sum of the squared volume error and squared specificyield error. The error for the estimate of total groundwater storage in all the HGUs of a valley basin was estimated as the square root of the sum of the squared errors for each HGU storage estimate, but in units of volume. An approximate lower limit for each storage estimate was determined by taking the storage estimate and subtracting 1.96 times the error of the storage estimate (in volumetric units); similarly, an approximate upper limit was determined by adding 1.96 times the error to the storage estimate. Although standard statistical procedures were used to propagate errors and determine the upper and lower limits of the storage estimates, the uncertainty of assigning volume and specific-yield errors requires emphasizing that the estimates of error in reported storage figures are only approximations. The results, however, do provide a reasonable and qualitative characterization of the amount of uncertainty associated with the storage estimates.

\section{Groundwater Storage Estimates}

Estimates of the total groundwater storage in aquifers in the Hualapai Valley, Detrital Valley, and Sacramento Valley basins are 14.1, 9.8, and $35.1 \mathrm{~km}^{3}$, respectively (table 4). For the Hualapai Valley and Sacramento Valley basins, the approach of determining independent groundwater storage estimates for multiple HGUs and then adding them together for a total groundwater storage estimate resulted in a lower uncertainty in the total estimate relative to the uncertainties in the individual estimates. For example, the approximate error in the estimated total groundwater storage was 20 percent for the Sacramento Valley basin, whereas for individual HGUs the error ranged from 21 to 50 percent (table 4).

Estimates of the total groundwater storage in the Hualapai Valley basin include independent calculations for the SFBF, UUBF, and PCBF HGUs (fig. 25; table 4). The total groundwater storage in basin fill aquifers of the three HGUs in this valley basin is estimated to be $14.1 \mathrm{~km}^{3}$. Accounting for the uncertainty in the data, however, this estimate could be as low as $6.8 \mathrm{~km}^{3}$ or as high as $21.4 \mathrm{~km}^{3}$ (table 3). Most of the estimated total groundwater storage is in the UUBF HGU$9.3 \mathrm{~km}^{3}$. The SFBF HGU contains a similar volume within the valley basin; however, together they hold only about a third as much storage (3.3 $\mathrm{km}^{3}$; table 3). Ivanich and Conway (2009) estimated a similar total groundwater storage as in this study, $12.4 \mathrm{~km}^{3}$, for a specific yield of 8 percent.

The Detrital Valley basin is defined by a single UUBF HGU. This HGU contains a predominance of fined-grained over coarse-grained basin fill and so it was assigned a specific yield of 8 percent. Water-level data and interpreted resistivity profiles indicate the basin fill is largely fine grained and unsaturated in the northern Detrital subbasin (figs. 18, 25), and so the groundwater storage in much of this subbasin was considered negligible. The total groundwater storage in basin fill aquifers in the Detrital Valley, largely in the central and southern subbasins, is estimated to be $9.8 \mathrm{~km}^{3}$. Accounting for the uncertainty in the data, however, this estimate could be as low as $0.1 \mathrm{~km}^{3}$ or as high as $19.4 \mathrm{~km}^{3}$ (table 4). Mason and others (2007) estimated less total groundwater storage than in this study, $4.9 \mathrm{~km}^{3}$, using a specific yield of 8 percent. These two estimates differ partly because Mason and others included a layer of unsaturated basin fill beneath overlying saturated basin fill within the central Detrital subbasin. Therefore, this study considers the total volume of saturated basin fill and exceeded that reported by Mason and others (2007).

Estimates of groundwater storage in the Sacramento Valley basin include independent calculations for the SCBF, SFBF, UUBF, and PCBF HGUs (fig. 25; table 4). The total groundwater storage in basin fill aquifers of these four HGUs is estimated to be $35.1 \mathrm{~km}^{3}$. Accounting for the uncertainty in the data, however, this estimate could be as low as 21.7 $\mathrm{km}^{3}$ or as high as $48.5 \mathrm{~km}^{3}$ (table 4). Although little of the total groundwater is stored in the SFBF HGU, the other three HGUs hold similar groundwater storage $\left(10-12.6 \mathrm{~km}^{3}\right)$. The percentage of total groundwater storage held in the PCBF HGU is 36 percent for the Sacramento Valley basin, much greater than that for the other two basins. Conway and Ivanich (2008) estimated the total groundwater in the Sacramento Valley basin to be about $11.7 \mathrm{~km}^{3}$ for a specific yield of 8 percent. Their estimate is lower than that in this study because they used a lower specific yield and a smaller volume of saturated basin fill.

\section{Summary}

This report describes the use of geologic information, well-log lithologic data, a basin geometry model, and interpreted resistivity profiles to construct a hydrogeologic framework and to estimate groundwater storage in the Hualapai Valley, Detrital Valley, and Sacramento Valley basins. The hydrogeologic framework was constructed to describe how the bedrock and basin fill influence the movement and storage of groundwater within each of these three valley basins. Information from the hydrogeologic framework was used to guide delineation of hydrogeologic units (HGUs), defined primarily on the basis of sedimentary lithology. The different sedimentary lithologies in the basin fill resulted from different depositional environments - primarily lacustrine/playa, shoreline, and alluvial fan. We used the HGUs and associated specific yields to estimate the total groundwater storage in each valley basin.

The basin geometry model indicates that the Hualapai Valley basin is underlain by three subbasins that differ in size 


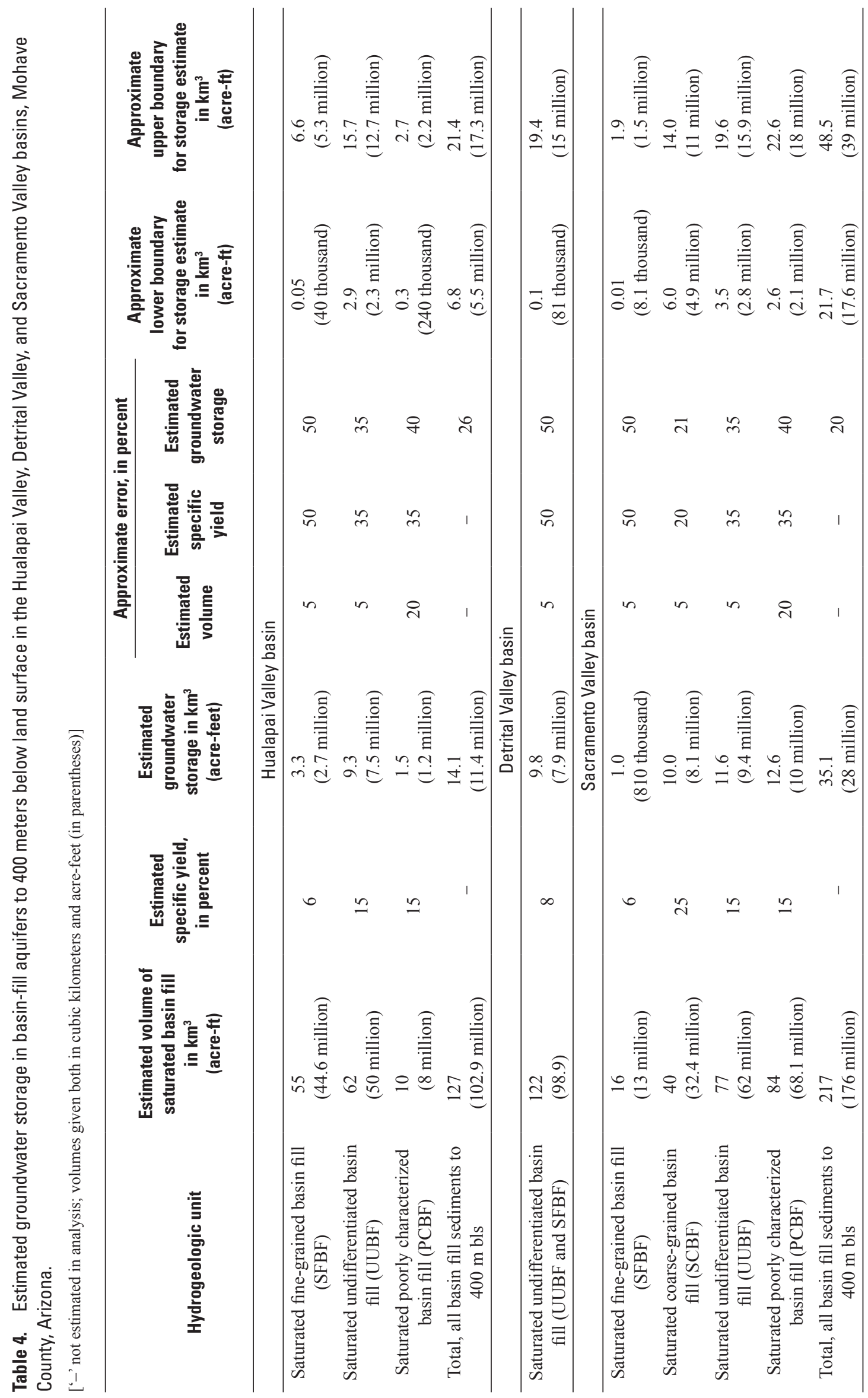


and depositional setting: the Kingman, Hualapai, and southern Gregg subbasins. Basin fill in the Kingman subbasin is characterized by alluvial-fan deposits. Basin fill sediments in the Hualapai subbasin is characterized as alluvial-fan and playa deposits overlying evaporite deposits, including as much as $1,000 \mathrm{~m}$ of halite. Basin fill in the southern Gregg subbasin is characterized by alluvial-fan deposits overlying limestone. Basin fill in the Hualapai Valley basin consists of consolidated sedimentary deposits overlain by primarily unconsolidated basin fill. The basin fill is more than 4,000 $\mathrm{m}$ thick in the deepest part of the valley basin but averages 0 to $100 \mathrm{~m}$ in thickness elsewhere. The lithologic basin fill units within the subbasins were deposited in alluvial-fan, shoreline, and playa environments. Total groundwater storage is estimated to be $14.1 \mathrm{~km}^{3}$.

The basin geometry model indicates that the elongate north-south Detrital Valley basin is underlain by three subbasins that appear to be formed by a series of opposing halfgraben faults and in various depositional settings: the northern Detrital, central Detrital, and southern Detrital subbasins. Basin fill in the two northern subbasins include playa deposits consisting of gypsum/anhydrite and halite sequences; whether they occur in the southern subbasin is unknown. Basin fill in the southern Detrital subbasin generally consists of alluvialfan deposits. Basin fill in the Detrital Valley basin consists of sedimentary deposits, overlain by unconsolidated to consolidated basin fill. The surface geology consists of Holocene valley-axial wash, alluvial-fan, and playa deposits. Total groundwater storage is estimated to be $9.8 \mathrm{~km}^{3}$.

The basin geometry model infers three subbasins in the Sacramento Valley basin: the Chloride, Golden Valley, and Dutch Flat subbasins. Broad interpretation of resistivity profiles and limited well-log lithologic data in the Chloride subbasin suggest unsaturated basin fill overlying saturated undifferentiated medium-grained to mostly fine-grained basin fill. Interpretation of resistivity profiles and well-log lithologic data in the Golden Valley subbasin suggests saturated medium- to coarse-grained basin fill in the northern part overlying fine-grained basin fill in the southern part. Little is known about the Dutch Flat subbasin and few data are available to interpret subsurface lithology. Basin fill in the Sacramento Valley basin consists of unconsolidated and consolidated sedimentary deposits, including fine-grained deposits in the southern part of the basin, alluvial-fan deposits veneering the pediment along the east side, and axial valley deposits along the main washes. The fine-grained deposits interfinger laterally with coarser grained alluvial-fan deposits. Unlike in the Hualapai Valley and Detrital Valley basins, no apparent evaporite deposits occur in the Sacramento Valley basin. Estimated groundwater storage for the whole aquifer is $28.5 \mathrm{~km}^{3}$.

\section{References Cited}

Alley, W.M., 2007, Another water budget myth-the significance of recoverable ground water in storage: Ground water, v. 45 , no. 3 , p. 251.

Annan, A.P., and Lockwood, R., 1991, An application of airborne GEOTEM* in Australian conditions: Exploration Geophysics, v. 22, no. 1, p. 5-12.

Anning, D.L., Truini, M., Flynn, M.E., and Remick, W.H. 2007, Groundwater occurrence and movement, 2006, and water-level changes in the Detrital, Hualapai, and Sacramento Valley Basins, Mohave County, Arizona: U.S. Geological Survey Scientific Investigation Report 2007-5182, $24 \mathrm{p}$.

Arizona Department of Economic Security, 2006, 2005 DES estimates - population growth since [http://www.workforce. az.gov/population-estimates.aspx, accessed January 7 , 2013].

Arizona Department of Water Resources, 2009, Groundwater site inventory database: Arizona Department of Water Resources [available at http://gisweb.azwater.gov/ waterresourcedata/, accessed Jan. 7, 2013].

Beard, L.S., Kennedy, J., Truini, M., and Felger, T., 2011, Geologic map of Detrital, Hualapai, and Sacramento basins and surrounding areas, northwest Arizona: U.S. Geological Survey Open-File Report 2011-1225, 58 p.

Bills, D.J., Flynn, M.E., and Monroe, S.A., 2007, Hydrology of the Coconino Plateau and adjacent areas, Coconino and Yavapai Counties, Arizona: U.S. Geological Survey Scientific Investigation Report 2005-5222, 101 p.

Blasch, K.W., Hoffmann, J.P., Graser, L.F., Bryson, J.R., and Flint, A.L., 2006, Hydrogeology of the upper and middle Verde River watersheds, central Arizona: U.S. Geological Survey Scientific Investigations Report 2005-5198, 115 p.

Bohannon, R.G., 1984, Nonmarine sedimentary rocks of Tertiary age in the Lake Mead region, southeastern Nevada and Northwestern Arizona, U.S. Geological Survey Professional Paper 1259, 72 p.

Brown, S.G., Davidson, E.S., Kister, L.R., and Thomsen, B.W., 1966, Water resources of Fort Huachuca Military Reservation, southeastern Arizona: U.S. Geological Survey Water Supply Paper 1819-D, 57 p.

Chow, V.T., 1964, Handbook of applied hydrology: a compendium of water-resources technology (1st ed): New York, McGraw-Hill, 1,468 p. 
Coes, A.L., and Pool, D.R., 2007, Ephemeral-stream channel and basin-floor infiltration and recharge in the Sierra Vista subwatershed of the upper San Pedro basin, southeastern Arizona, in Stonettrom, D.A., Conttantz, J., Ferre, T.P.A., and Leake, S.A., eds., Ground-water recharge in the arid and semiarid Southwestern United States: U.S. Geological Survey Professional Paper 1703-J, p. 253-311.

Conway, B. D., and Ivanich, P.A., 2008, Preliminary estimate of groundwater in storage for the Sacramento Valley groundwater basin, Mohave County, Arizona: Arizona Department of Water Resources Open File Report Number $10,28 \mathrm{p}$.

Davis, W.E., and Conradi, A. Jr., 1981, Bouguer gravity map of Hualapai Valley, Mohave County, Arizona: U.S. Geological Survey Open-File Report 81-770, 8 p., scale 1:250,000.

Dickinson, J.E., Pool, D.R., Groom, R.W., and Davis, L.J., 2009, Inference of lithologic distributions in an alluvial aquifer using airborne transient electromagnetic surveys: Geophysics, v. 75, no. 4, p. WA149-WA161.

Dickinson, J.E., Kennedy, J.R., Pool, D.R., Cordova, J.T., Parker, J.T., Macy, J.P., and Thomas, B., 2010, Hydrologic framework of the middle San Pedro watershed, southeastern Arizona: U.S. Geological Survey Scientific Investigation Report 2010-5126, 36 p.

Dillenburg, R.A., 1987, Map showing groundwater conditions in the Detrital Wash Basin, Mohave County, Arizona - 1987: Arizona Department of Water Resources Hydrologic Map Series Report 14, scale 1:125,000.

Dobrin, M.B., and Savit, C.H., 1988, Introduction to geophysical prospecting: New York, McGraw-Hill, 867 p.

Driscoll, F. G., 1986, Groundwater and wells: St. Paul, Minn., Johnson Division, $67 \mathrm{p}$.

Faulds, J.E., 1995, Geologic map of the Mount Davis quadrangle, Nevada and Arizona: Nevada Bureau of Mines and Geology Map 105, 4 p., scale 1:24,000.

Faulds, J.E., Schreiber, B.C., Reynolds, S.J., Gonzalez, L., and Okaya, D., 1997, Origin and paleogeography of an immense, nonmarine Miocene salt deposit in the Basin and Range (western USA): Journal of Geology, v. 105, p. 19-36.

Faulds, J.E., Smith, E.I., and Gans, P.B., 1999, Spatial and temporal patterns of magmatism and extension in the northern Colorado River extensional corridor, Nevada and Arizona - a preliminary report: Nevada Petroleum Society Guidebook, p. 171-183.
Faulds, J.E., Feuerbach, D.L., Miller, C.F., and Smith, E.I., 2001, Cenozoic evolution of the northern Colorado River extensional corridor, southern Nevada and northwest Arizona: American Association of Petroleum Geologists, Pacific Section Publication GB 78 (Utah Geological Association Publication 30), p. 239-272.

Faulds, J.E., Howard, K.A., and Duebendorfer, E.M., 2008, Cenozoic evolution of the abrupt Colorado Plateau-Basin and Range boundary, northwest Arizona - a tale of three basins, immense lacustrine-evaporite deposits, and the nascent Colorado River in Duebendorfer, E.M., and Smith, E.I., eds., Field guide to plutons, volcanoes, faults, reefs, dinosaurs, and possible glaciation in selected areas of Arizona, California, and Nevada: Geological Society of America Field Guide 11, p. 119-151.

Fenneman, N.M., 1931, Physiography of western United States (1st ed.): New York, McGraw-Hill, 534 p.

Geosoft, Inc., 2008, Oasis montaj and GM-SYS 3D software for geophysical modeling.

Freethey, G.W., 1982, Hydrologic analysis of the upper San Pedro Basin from the Mexico-United States international boundary to Fairbanks, Arizona: U.S. Geological Survey Open-File Report 82-752, 64 p.

Garner, B.D., and Truini, M., 2011, Groundwater budgets for Detrital, Hualapai, and Sacramento Valleys, Mohave County, Arizona, 2007-2008: U.S. Geological Survey Scientific Investigation Report 2011-5159, 34 p.

Gettings, M.E., and Houser, B.B., 2000, Depth to bedrock in the upper San Pedro Valley, Cochise County, southeastern Arizona: U.S. Geological Survey Open-File Report 2000138 [available at http://pubs.usgs.gov/of/2000/of00-138/, accessed Jan.7, 2013].

Gillespie, J.B., and Bentley, C.B., 1971, Geohydrology of Hualapai and Sacramento Valleys, Mohave County, Arizona: U.S. Geological Survey Water-Supply Paper 1899-H, 37 p., 2 pls., scale 1:125,000.

Gillespie, J.B., Bentley, C.B., and Kam, W., 1966, Basic hydrologic data of the Hualapai, Sacramento, and Big Sandy Valleys, Mohave County, Arizona: Arizona Land Department Water-Resources Report 26, 39 p.

Hildenbrand, T.G., Briesacher, A., Flanagan, G., Hinze, W.J., Hittelman, A.M., Keller, G.R., Kucks, R.P., Pluoff, D., Roest, W., Seeley, J., Smith, D.A., and Webring, M., 2002, Rationale and operational plan to upgrade the U.S. Gravity database: U.S. Geological Survey Open-File Report 02-463, $14 \mathrm{p}$. 
Hinze, W.J., Aiken, C., Brozena, J., Coakley, B., Dater, D., Flanagan, G., Forsberg, R., Hildenbrand, T., Keller, G.R., Kellogg, J., Kucks, R., Lee, X., Mainville, A., Morin, R., Pilkington, M., Plouff, D., Ravat, D., Roman, D., UrrutiaFucugauchi, J., Véronneau, M., Webring, M., and Winester, D., 2005, New standards for reducing gravity data-The North American gravity database, Geophysics, v. 70, no. 4, p. J25-J32.

House, P.K., Pearthree, P.A., Howard, K.A., Bell, J.W., Perkins, M.E., Faulds, J.E., and Brock, A.L., 2005, Birth of the lower Colorado River-stratigraphic and geomorphic evidence for its inception near the conjunction of Nevada, Arizona, and California, in Pederson, J., and Dehler, C.M., eds., Interior Western United States: Geological Society of America Field Guide 6, p. 357-387.

Howard, K.A., and John, B.E., 1987, Crustal extension along a rooted system of imbricate low-angle faults - Colorado River extensional corridor, California and Arizona, in Coward, M.P., Dewey, J.F., and Hancock, P.L., eds., Continental extensional tectonics: Geological Society of London Special Publication 28, p. 299-311.

Howard, K.A., Nielson, J.E., Wilshire, H.G., Nakata, J.K., Goodge, J.W., Reneau, S.L., John, B.E., and Hansen, V.L, 1999, Geologic map of the Mohave Mountains area, Mohave County, western Arizona: U.S. Geological Survey Miscellaneous Investigations Series Map I-2308, scale 1:100,000.

Ivanich, P.A., and Conway, B.D., 2009, Preliminary estimate of groundwater in storage for the Hualapai Valley groundwater basin, Mohave County, Arizona: Arizona Department of Water Resources Open-File Report Number 11, 31 p.

Jachens, R.C., and Moring, B.C., 1990, Maps of the thickness of Cenozoic deposits and the isostatic residual gravity over basement for Nevada: U.S. Geological Survey Open-File Report 90-404, 15 p.

LaFehr, T.R., 1991, An exact solution for the gravity curvature (Bullard B) correction: Geophysics, v. 56, no. 8, p. 1179-1184.

Laney, R.L., 1979, Geohydrologic reconnaissance of Lake Mead National Recreation Area-Hoover Dam to Temple Bar, Arizona: U.S. Geological Survey Open-File Report 79-689, scale 1:62,500.

Langenheim, V.E., Beard, L.S., and Faulds, J.E., 2010, Implications of geophysical analysis on basin geometry and fault offsets in the northern Colorado River extensional corridor and adjoining Lake Mead region, Nevada and Arizona, in Umhoefer, P.J., Beard, L.S., and Lamb, M.A., eds., Miocene tectonics of the Lake Mead region, central Basin and Range: Geological Society of America Special Paper, 21 p.
Mason, D.A., Ivanich, P.A., Conway, B.D., Kurtz, J.A., and Winn, M.T., 2007, Preliminary estimate of water in storage for the Detrital Valley groundwater basin, Mohave County, Arizona: Arizona Department of Water Resources OpenFile Report Number 9, 31 p.

Metzger, D.G. and Loeltz, O.J., 1973, Geohydrology of the Needles area, Arizona, California, and Nevada: U.S. Geological Professional Paper 486-J, 54 p.

Nabighian, M.N., and Macnae, J.C., 1987, Time domain electromagnetic prospecting methods, in Nabighian, M.N., ed., Electromagnetic methods in applied geophysics: Tulsa Okla., Society of Exploration Geophysics, v. 2, 992 p.

National Atlas, 2010, Map Maker [http://www.nationalatlas. gov/mapmaker, accessed Jan. 7, 2012].

Nielson, J.E., Lux, D.R., Dalrymple, G.B., and Glazner, A.F., 1990, Age of the Peach Springs Tuff, southeastern California and western Arizona: Journal of Geophysical Research, v. 95, no. B1, p. 571-580.

Oppenheimer, J.M., and Sumner, J.S., 1980, Basin geometry model map, Basin and Range province, Arizona: Tucson Ariz., University of Arizona, Department of Geosciences, Laboratory of Geophysics, scale 1:1,000,000.

Pan-America Center for the Earth and Environmental Studies, 2008, Gravity and magnetic dataset repository [http:// research.utep.edu/Default.aspx?tabid=37229, accessed Jan. $7,2013]$.

Parker, J.T.C., Steinkampf, W.C., and Flynn, M.E., 2005, Hydrogeology of the Mogollon Highlands, central Arizona: U.S. Geological Survey Scientific Investigations Report 2004-5294, 87 p.

Pool, D.R., and Dickinson, J.E., 2007, Ground-water flow model of the Sierra Vista subwatershed and Sonoran portions of the upper San Pedro basin, southeastern Arizona, United States, and northern Sonora, Mexico: U.S. Geological Survey Scientific Investigations Report 2006-5228, 48 p.

Pool, D.R., and Coes, A.L., 1999, Hydrogeologic investigations of the Sierra Vista subwatershed of the upper San Pedro Basin, Cochise County, southeast Arizona: U.S. Geological Survey Water-Resources Investigations Report 99-4197, 41 p.

Rascona, S.J., 1991, Map showing groundwater conditions in the Sacramento Valley Basin, Mohave County, Arizona-1991: Arizona Department of Water Resources Hydrologic Map Series Report Number 21, scale 1:125,000.

Remick, W.H., 1981, Map showing groundwater conditions in the Hualapai Basin Area, Mohave County, Arizona-1980: State of Arizona Department of Water Resources Hydrologic Map Series Report Number 4, scale 1:125,000. 
Richard, S.M., Reynolds, S.J., Spencer, J.E., and Pearthree, P.A., 2000, Geologic map of Arizona: Arizona Geological Survey Map M-35, scale 1:1,000,000.

Saltus, R.W., and Jachens, R.C., 1995, Gravity and basindepth maps of the Basin and Range Province, western United States: U.S. Geological Survey Geophysical Investigations Map GP-1012, scale 1:2,500,000.

Simpson, R.W., Jachens, R.C., and Blakely, R.J., 1983, AIRYROOT - a FORTRAN program for calculating the gravitational attraction of an airy isostatic root out to $166.7 \mathrm{~km}$ : U.S. Geological Survey Open-File Report 83-883, 66 p.

Spangler, D.P., 1968, Application of the gravity survey method to watershed hydrology: Ground Water, v. 6, no. 6, p. 21-26.

Spencer, J.E., and Pearthree, P.A., 2005, Abrupt initiation of the Colorado River and initial incision of the Grand Canyon: Arizona Geology, vol. 35, no. 4, 6 p.

Telford, W.M., Geldart L.P., Sheriff, R.E., and Keys, D.A., 1976, Applied geophysics (1st ed): Cambridge, U.K., Cambridge University Press.

Towne, D.C., Freark, M.C., and Stephenson, L.W., 2001, Ambient groundwater quality of the Sacramento Valley basin - a 1999 baseline study: Arizona Department of Environmental Quality Open File Report 2001-04, 78 p.

Towne, D.C., and Rowe, L., 2007, Ambient groundwater quality of the Hualapai Valley basin — a 2000 baseline study: Arizona Department of Environmental Quality Open File Report 07-05, 83 p.

Towne, D.C., and Stephenson, L.W., 2003, Ambient groundwater quality of the Detrital Wash basin —a 2002 baseline study: Arizona Department of Environmental Quality Open File Report 2003-03, 65 p.

U.S. Census Bureau, 2011, State and county quick facts [http://quickfacts.census.gov/qfd/states/04/04015.html, accessed Jan. 7, 2013].

Western Regional Climate Center, 2005, Arizona Climate Summaries-2005 [http://www.wrcc.dri.edu/summary/ climsmaz.html, accessed Jan. 7, 2013].

Young, R.A., 2001, Geomorphic, structural, and stratigraphic evidence for Laramide uplift of the southwestern Colorado Plateau margin of NW Arizona: American Association of Petroleum Geologists, Pacific Section Publication GB 78, Utah Geological Association Publication 30, p. 227-237.
Produced in Menlo Park Publishing Service Center, California

Manuscript approved for publication July 11, 2012

Edited by George Havach and Claire Landowski

Layout and design by Vivian T. Nguyen 
